\title{
Biomembrana de quitosana-alginato na cicatrização de úlceras cutâneas em ratos
}

Dissertação apresentada ao Programa de Pós-Graduação Interunidades em Biotecnologia USP/Instituto Butantan/IPT, para obtenção do Título de Mestre em Biotecnologia. 
GUILHERME FERREIRA CAETANO

\section{Biomembrana de quitosana-alginato na cicatrização de úlceras cutâneas em ratos}

Dissertação apresentada ao Programa de Pós-Graduação Interunidades em Biotecnologia USP/Instituto Butantan/IPT, para obtenção do Título de Mestre em Biotecnologia.

Área de concentração: Biotecnologia

Orientador: Prof. Dr. João Tadeu RibeiroPaes

Co-orientador: Prof. Dr. Marco Andrey Cipriani Frade

Versão original 
DADOS DE CATALOGAÇÃO NA PUBLICAÇÃO (CIP)

Serviço de Biblioteca e Informação Biomédica do

Instituto de Ciências Biomédicas da Universidade de São Paulo

(C) reprodução total

\section{Caetano, Guilherme Ferreira.}

Biomembrana de quitosana-alginato na cicatrização de úlceras cutâneas em ratos / Guilherme Ferreira Caetano. -- São Paulo, 2012.

Orientador: Prof. Dr. João Tadeu Ribeiro Paes.

Dissertação (Mestrado) - Universidade de São Paulo. Instituto de Ciências Biomédicas. Programa de Pós-Graduação Interunidades em Biotecnologia USP/IPT/Instituto Butantan. Área de concentração: Biotecnologia. Linha de pesquisa: Cicatrização.

Versão do título para o inglês: Chitosan-alginate biomembrane on wound healing in rats.

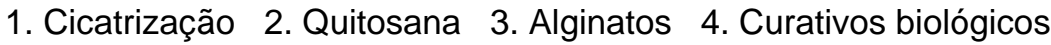
I. Paes, Prof. Dr. João Tadeu Ribeiro II. Universidade de São Paulo. Instituto de Ciências Biomédicas. Programa de Pós-Graduação Interunidades em Biotecnologia USP/IPT/Instituto Butantan III. Título. 
Candidato(a): $\quad$ Guilherme Ferreira Caetano.

Título da Dissertação: Biomembrana de quitosana-alginato na cicatrização de úlceras cutâneas em ratos.

Orientador(a): $\quad$ Prof. Dr. João Tadeu Ribeiro Paes.

A Comissão Julgadora dos trabalhos de Defesa da Dissertação de Mestrado, em sessão pública realizada a ....................,
( ) Aprovado(a)
( ) Reprovado(a)

Examinador(a): Assinatura: .

Nome:

Instituição:

Examinador(a): Assinatura:

Nome:

Instituição:

Presidente: Assinatura:

Nome:

Instituição: 


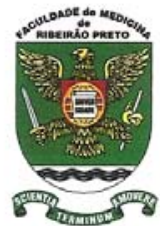

\section{UNIVERSIDADE DE SÃO PAULO \\ FACULDADE DE MEDICINA DE RIBEIRÃO PRETO \\ - Comissão de Ética em Experimentação Animal -}

\section{CE R T I F I C A D O}

Certificamos que o Protocolo para Uso de Animais em Experimentação $\mathrm{n}^{\circ} \mathbf{0 8 5} / \mathbf{2 0 1 1}$, sobre o projeto intitulado "Biomembrana de quitosana e alginato na cicatrização de úlceras cutâneas em ratos", sob a responsabilidade do Professor Doutor Marco Andrey Cipriani Frade está de acordo com os Princípios Éticos na Experimentação Animal adotado pelo Colégio Brasileiro de Experimentação Animal (COBEA) e foi APROVADO em reunião de 25 de julho de 2011.

(We certify that the protocol $n^{\circ} 085 / 2011$, about "Biomembrane of chitosan and alginate on cutaneous wound healing in rats", agrees with the ETHICAL PRINCIPLES IN ANIMAL RESEARCH adopted by Brazilian College of Animal Experimentation (COBEA) and was approved by the College of Medicine of Ribeirão Preto of the University of São Paulo - Ethical Commission of Ethics in Animal Research (CETEA) in 07/25/2011.

Ribeirão Preto, 25 de julho de 2011.

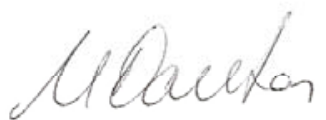

Prof. Dr. Márcio Dantas

Presidente da Comissão de Ética em Experimentação Animal 
Dedico este trabalho aos meus queridos pais Qegiane e Qeginaldo, meus exemplos de vida. 


\section{AGRADECIMENTOS}

Primeiramente à Deus, o grande Pai de todos, por ter me iluminado nesta minha trajetória cheia de pedras e barreiras, mas que com sua abençoada sabedoria guiou-me nos momentos mais difíceis.

Ao meu orientador Prof. Dr. João Tadeu Ribeiro-Paes pelo enorme incentivo dado ao meu trabalho. Todos sabíamos que seria dificílimo no início, porém com todo empenho e dedicação conseguimos chegar ao fim.

Ao meu co-orientador Marco Andrey Cipriani Frade. Meus sinceros agradecimentos por ter aberto as portas do laboratório e me aceitado como parte do grupo de Dermatologia para o desenvolvimento do meu trabalho. Obrigado pela dedicação, paciência apoio e principalmente credibilidade.

Aos funcionários do Programa de Pós-Graduação em Biotecnologia por todo suporte e ajuda fornecida ao longo do meu trabalho.

Aos amigos do Lab. GenteCel da Unesp-Assis, em especial ao Rodrigo Kozma e Valter Abraão. Obrigado pela confiança de ambos em meu trabalho e pelo suporte fornecido. Estivemos no mesmo barco todo esse tempo e sabemos das dificuldades encontradas e o quão importante é quando sabemos em quem procurar ajuda.

A todos os amigos do grupo de Dermatologia da FMRP-USP, departamento de Clínica Médica. Gostaria de agradecer em especial ao Dr. Thiago Antônio Moretti de Andrade, ao Dr. Márcio Fronza e Marcel Nani Leite pelos ensinamentos e credibilidade ao longo do meu trabalho. Obrigado pelo esforço individual de vocês em cada "batalha travada".

"É camelando que se aprende; bola pra frente".

À técnica Maria Aparecida Nunes, do Laboratório de Cultura Celular da Dermatologia da FMRP-USP. Obrigado "Cici" pela grande ajuda com os experimentos e pelos ensinamentos transmitidos.

À técnica Paula Payão do Laboratório de Nutrição da FMRP-USP. Obrigado pela paciência e ajuda nas leituras das plaquinhas de ELISA.

Aos técnicos Kléber Loureiro e Edna Moraes da FORP-USP. Obrigado pela paciência e pelas perfeitíssimas lâminas histológicas que vocês fizeram.

Aos funcionários do Biotério do Departamento de Clínica Médica da FMRP-USP: Adalberto, Maurício e Roni, pela ajuda nos experimentos e no cuidado com os animais.

À CAPES pelo apoio financeiro. 
À minha querida e amada família: mamãe Regiane, papai Reginaldo, meu lindo irmão Marcelo (Tché), minha linda irmã Ana Laura e aos meus também pais Mariano e Denise. Muito Obrigado por toda dedicação em minha educação, em meu crescimento e por todo aprendizado de vida. Nada mais sou que um espelho de todos vocês.

À minha namorada Ana Beatriz Sant' Ana do Nascimento por sempre estar ao meu lado nos momentos fáceis e difíceis. Agradeço cada carinho, apoio e confiança que contribuíram efetivamente em toda minha trajetória.

À todos os meus amigos e familiares que de alguma forma contribuíram para a realização desse trabalho e que por ventura não tenham sido mencionado, muito obrigado! 


\section{RESUMO}

CAETANO, G. F. Biomembrana de quitosana-alginato na cicatrização de úlceras cutâneas em ratos. 2012. 88 f. Dissertação (Mestrado em Biotecnologia) - Instituto de Ciências Biomédicas, Universidade de São Paulo, São Paulo, 2012.

Úlceras cutâneas necessitam de um longo tempo de tratamento, resultando em alto custo com cuidados médicos. Assim, a busca por substâncias terapêuticas cicatrizantes, atóxicas, de fácil acesso a população e baixo custo ganhou importância nos últimos anos. A quitosana e o alginato são bem conhecidos por suas propriedades cicatrizantes. A quitosana, polissacarídeo catiônico natural, renovável, biodegradável, biocompatível, atóxico, ativa macrófagos funcionais e aumenta a fibroplasia na área afetada. $\mathrm{O}$ alginato, polissacarídeo aniônico, biocompatível, hidrofílico e biodegradável, mantém a umidade no leito da lesão, promove a hemostasia e formação do tecido de granulação. $O$ objetivo do presente trabalho foi avaliar a eficácia da biomembrana de quitosana-alginato na cicatrização de úlceras cutâneas em ratos. Foram utilizados 65 ratos Wistar machos (200-220g), anestesiados com hidrato de cloral $4 \%(1.0 \mathrm{~mL} / 100 \mathrm{~g}$ do animal). Após tricotomia da região dorsal, duas excisões cirúrgicas foram feitas com punch histológico $(1,5 \mathrm{~cm}$ de diâmetro) atingindo todas as camadas da pele. Os animais foram divididos em grupos experimentais: BQA ( $n=25$, ambas as úlceras de cada animal receberam a biomembrana de quitosana-alginato préhidratada com soro fisiológico $0,9 \%$ ) e SF ( $n=25$, ambas as úlceras foram tratadas somente com soro fisiológico). Em seguida, todos os animais receberam curativo oclusivo de gaze e esparadrapo. Todas as úlceras foram hidratadas até o 70 dia e as biomembranas foram removidas somente no dia da eutanásia. $O$ grupo $\mathrm{GZ}$ ( $\mathrm{n}=15$, ambas as úlceras foram tratadas somente com gaze, sem hidratação e sem trocas diárias) foi utilizado somente para avaliar a reepitelização. Após 2, 7, 10, 14 e 21 dias do procedimento cirúrgico cinco animais/grupo foram eutanasiados e avaliou-se a reepitelização por meio do índice de cicatrização das úlceras. Uma biópsia de úlcera/cicatriz de cada animal foi coletada, fixada em formaldeído $3,7 \%$ tamponado, corada com hematoxilina e eosina e tricrômio de Gomori para quantificação de infiltrado inflamatório, fibroblastos, vasos sanguíneos e colagênese por meio do software ImageJ. A biópsia da outra úlcera foi utilizada para a dosagem de mieloperoxidase (MPO), para avaliar o infiltrado neutrofílico no tecido lesado, e dosagem de hidroxiprolina (OHP) para avaliar a colagênese. BQA aumentou o recrutamento de células inflamatórias para a lesão em relação à $S F$ já no $2^{\circ}$ dia $(p=0,0134)$. No 70 dia, houve redução das células inflamatórias no grupo BQA em relação ao 20 dia $(p=0,0038)$, enquanto em SF manteve-se constante. Ambos os grupos apresentaram infiltrado neutrofílico similar no 20 dia. No 70 dia, observou-se importante redução de MPO no BQA em relação ao 2ㅇ dia $(p=0,0326)$, e o SF apresentou-se superior a BQA $(p=0,0043)$. Assim, BQA parece ter estimulado a fase inflamatória, aumentando o recrutamento celular no 20 dia e regulando o estímulo no 7으. BQA apresentou maior fibroplasia no $7^{\circ}(p=0,0275)$ e no $14^{\circ}$ dia $(p=0,0086)$, diferente do grupo $S F$, além de maior colagênese no 210 dia $(p=0,0219)$, pelo método histológico. Em relação à $\mathrm{OHP}, \mathrm{BQA}$ apresentou maior colagênese em relação à SF no 2 o $(p=0,0042)$ e 210 dias $(p=0,0249)$, porém no 14 으 dia foi menor $(P=0,0010)$. As úlceras do grupo BQA no $7^{\circ}$ dia apresentaram-se mais reepitelizado que as do SF $(p=0,0006)$. Sendo assim, a biomembrana de quitosana-alginato atuou ativamente na fase inflamatória e estimulou a colagênese, acelerando a cicatrização das úlceras em ratos.

Palavras chave: Cicatrização. Quitosana. Curativos biológicos. 


\section{ABSTRACT}

CAETANO, G. F. Chitosan-alginate biomembrane on wound healing in rats. 2012. 88 p. (Masters thesis in Biotechnology) - Instituto de Ciências Biomédicas, Universidade de São Paulo, São Paulo, 2012.

Skin wounds require a long treatment time, resulting in high-cost medical care. Therefore, the search for new natural therapeutic healing substances, non-toxic, easy access to population and low cost has gained importance in recent years. Chitosan and alginate are well-known for healing properties. Chitosan, a natural cationic polymer, is biologically renewable, biodegradable, biocompatible, non-toxic, and it can enhancing functions of inflammatory cells, macrophages, and fibroblasts. Alginate, an anionic polymer, also biocompatible, hydrophilic and biodegradable, is able to maintain a physiologically moist microenvironment that promotes hemostasis and the formation of granulation tissue. The purpose of this study was to evaluate the effectiveness of chitosan-alginate biomembrane on wound healing in rats. A total of 65 male Wistar rats $(200-220 \mathrm{~g})$ were anaesthetized by $4 \%$ chloral hydrate $(1.0 \mathrm{~mL} / 100 \mathrm{~g}$ weight). After shaved the dorsal hair, two excisional wounds were performed by punch $(1.5 \mathrm{~cm}$ diameter) with depth of all the skin layers. Rats were divided in groups: BQA group ( $n=25$, both wounds of each rat received chitosanalginate biomembrane moistened with saline) and SF group $(n=25$, both wounds were treated only with saline). After this, the wounds received occlusive dressing with gauze and tape. All wounds were moistened daily up to the $7^{\text {th }}$ day and biomembrane were removed only on the sacrificed day. GZ group ( $n=15$, both wounds were treated only with gauze, no moistened and no daily changes) was added to evaluate the reepithelialization. On 2, 7, 10, 14 and 21 days post-injury, five rats of each group were euthanized and evaluated the reepithelialization by wound healing rate. One biopsy of wound/scar was harvested, fixed on $3,7 \%$ formalin, and stained with hematoxylin-eosin and Gomori's trichrome for quantification the inflammatory cells, fibroblasts, blood vessels and collagenesis by ImageJ software. Other one was used for myeloperoxidase assay (MPO), to evaluate the neutrophilic infiltrate on injured tissue, and by determining the levels of hydroxyproline $(\mathrm{OHP})$ to evaluate the collagenesis. BQA increased the recruitment of inflammatory cells to wound, different from SF $(p=0,0134)$ on $2^{\text {nd }}$ day. On $7^{\text {th }}$ day, BQA decreased inflammatory infiltrate relation to $2^{\text {nd }}$ day $(p=0,0038)$, whereas SF maintained the same and similar amount of inflammatory infiltrate than $B Q A$, both decreasing during the follow-up $(p>0,05)$. Regarding to MPO, both groups showed similar neutrophilic infiltrate on $2^{\text {nd }}$ day. On $7^{\text {th }}$ day, $B Q A$ showed an important MPO reduction relation to $2^{\text {nd }}$ day $(p=0,0326)$, whereas SF showed higher MPO than BQA $(p=0,0043)$. All groups showed low level of MPO during the follow-up $(p>0,05)$. Thus, BQA stimulated the inflammatory phase of wound healing, increasing inflammatory cells on $2^{\text {nd }}$ day and modulating this stimulus on $7^{\text {th }}$ day. BQA increased the recruitment of fibroblasts to wound on $7^{\text {th }}(p=0,0275)$ and $14^{\text {th }}(p=0,0086)$ days different from SF, in addition to collagenesis on $21^{\text {st }}(p=0,0219)$. By OHP assay, BQA showed higher collagenesis than SF on $2^{\text {nd }}(p=0,0042)$ and $21^{\text {st }}$ days $(p=0,0249)$, however on $14^{\text {th }}$ day SF showed more collagenesis than BQA $(p=0,0010)$. BQA showed more pronounced reepithelialization on $7^{\text {th }}$ day than $S F(p=0,0006)$. Chitosan-alginate biomembrane regulated the inflammatory phase and stimulated the collagenesis, accelerating the wound healing on rats.

Keywords: Wound healing. Chitosan. Biological dressings. 


\section{LISTA DE ILUSTRAÇÕES}

Figura 1 - Produção das biomembranas de quitosana-alginato.

Figura 2 - Confecção de duas úlceras cutâneas no dorso de cada animal.....

Figura 3 - Curativo oclusivo feito em cada animal após receberem os respectivos

tratamentos

Figura 4 - Suporte utilizado para aquisição das imagens.

Figura 5 - Biópsia da úlcera/cicatriz de cada animal para análise.

Figura 6 - Fotomicrografia da área ulcerada de ambos os grupos ao longo do seguimento.

Figura 7 - Quantificação do infiltrado inflamatório (por histomorfometria) das úlceras de ambos os grupos ao longo do seguimento.

Figura 8 - Quantificação da mieloperoxidase nas úlceras cutâneas de ambos os grupos ao longo do seguimento. .56

Figura 9 - Angiogênese nas úlceras cutâneas de ambos os grupos ao longo do seguimento.

Figura 10 - Fibroplasia nas úlceras cutâneas de ambos os grupos ao longo do seguimento. .58

Figura 11 - Fotomicrografia da área ulcerada de ambos os grupos ao longo do seguimento. 60

Figura 12 - Colagênese nas úlceras cutâneas de ambos os grupos ao longo do seguimento 60

Figura 13 - Colagênese nas úlceras cutâneas de ambos os grupos ao longo do seguimento.

Figura 14 - Reepitelização das úlceras cutâneas de ambos os grupos ao longo do seguimento.

Figura 15 - Reepitelização das úlceras cutâneas dos três grupos experimentais ao longo do seguimento 


\section{LISTA DE SIGLAS}

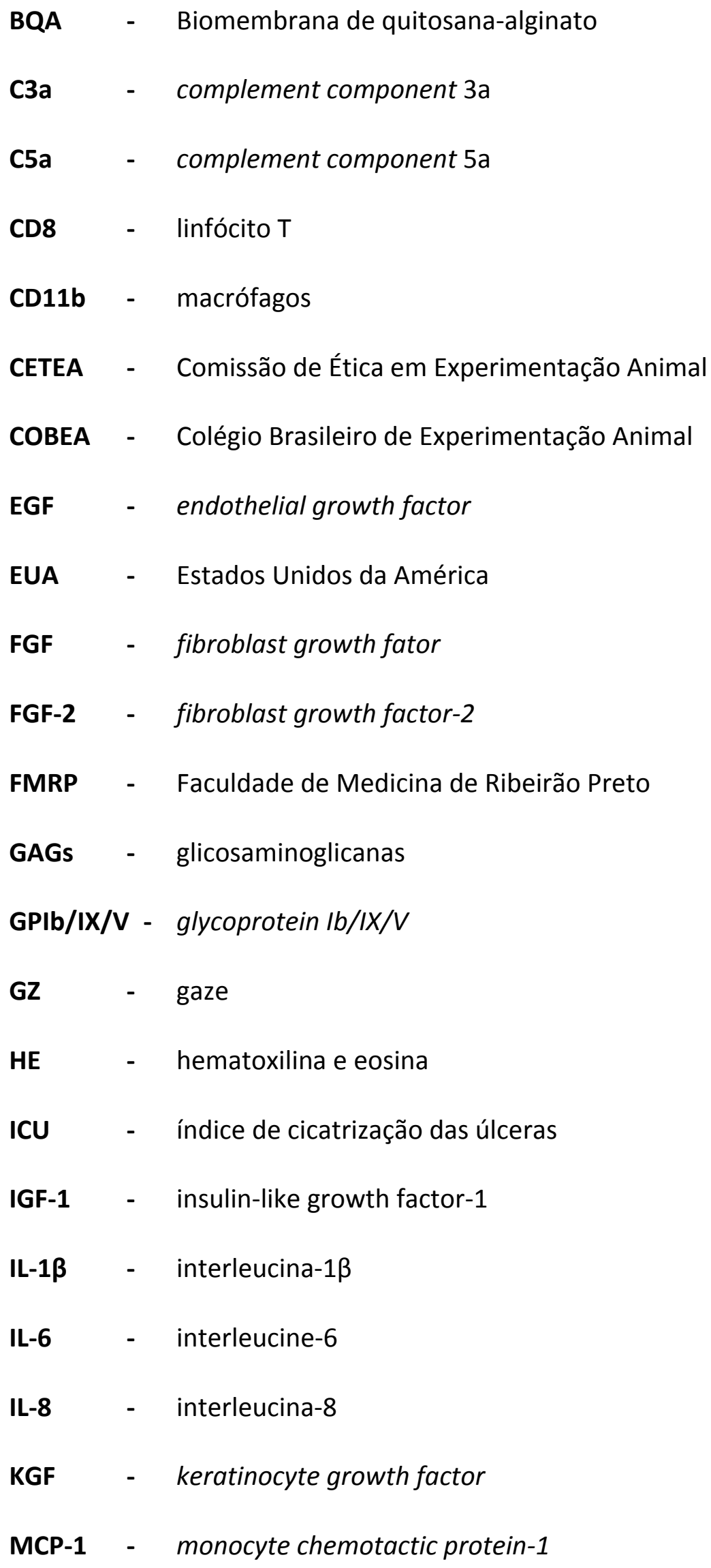




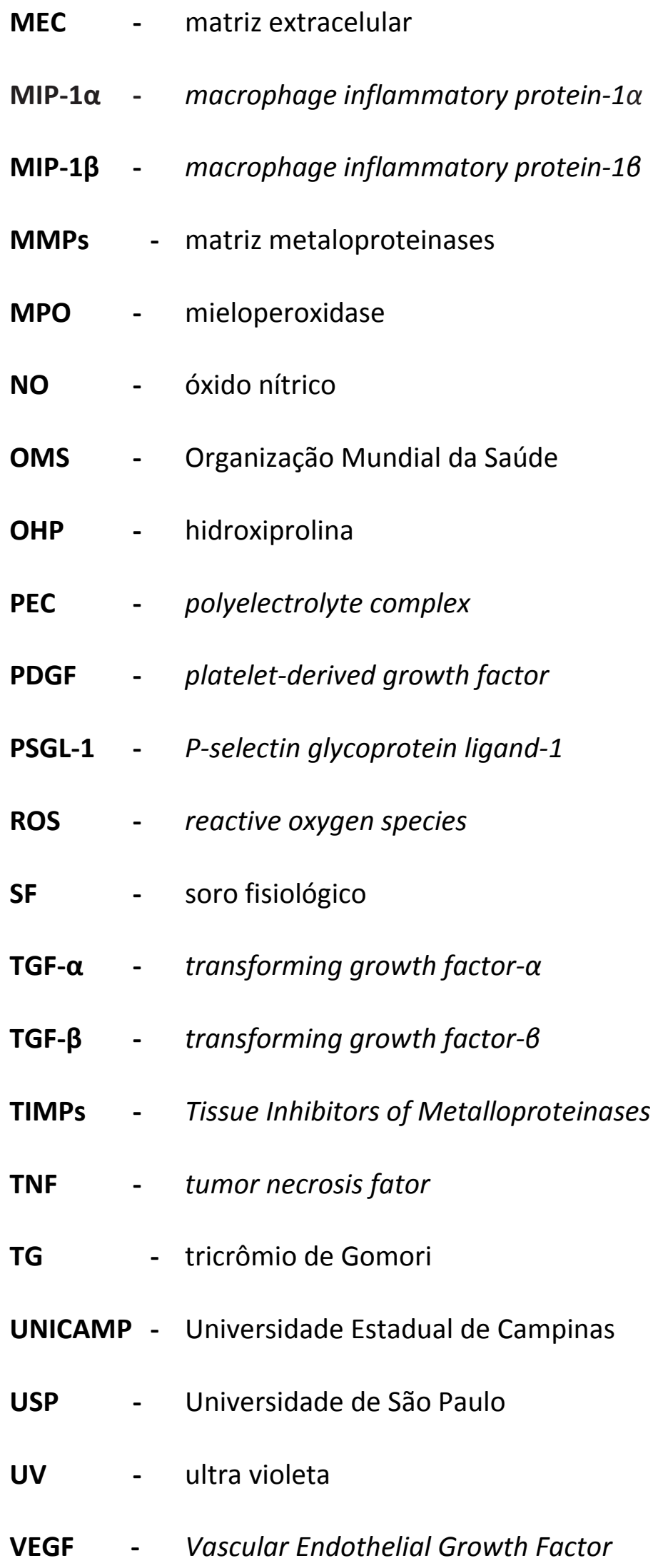




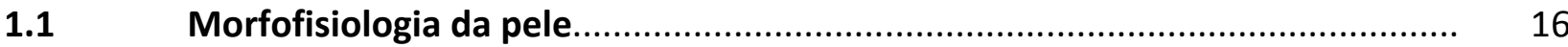

1.1.1 Epiderme

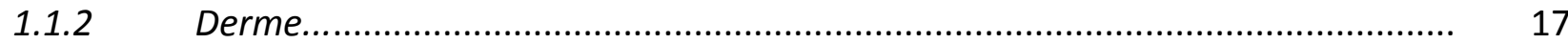

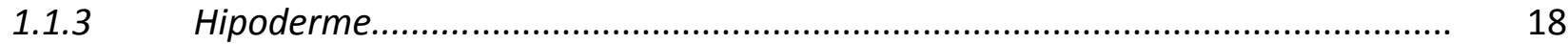

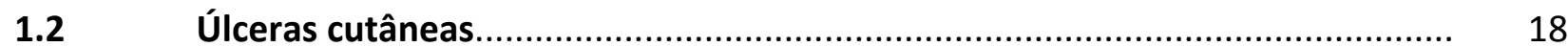

1.2.1 Úlceras cutâneas agudas e crônicas................................................................... 19

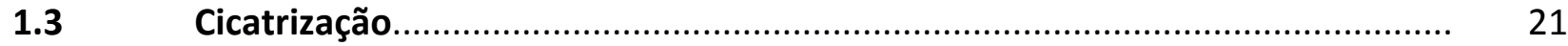

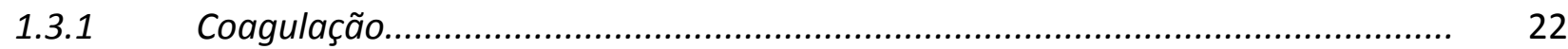

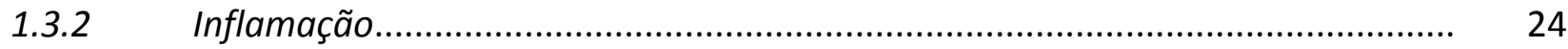

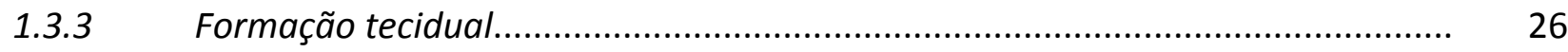

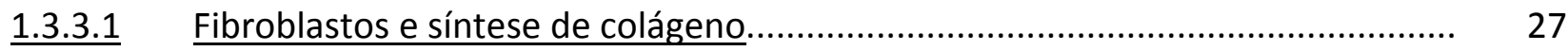

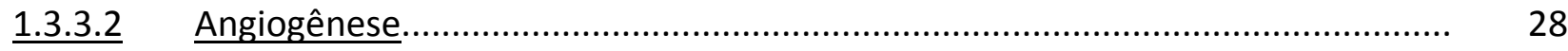

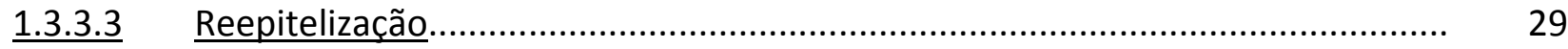

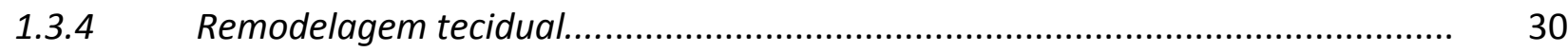

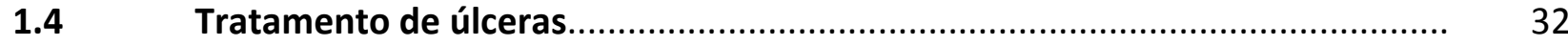

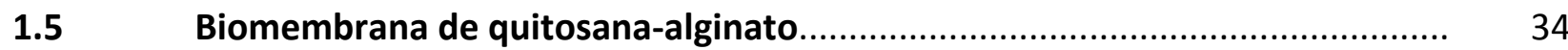

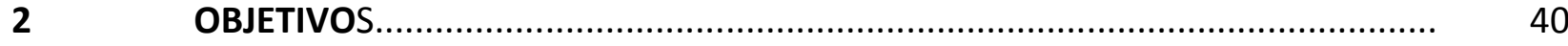

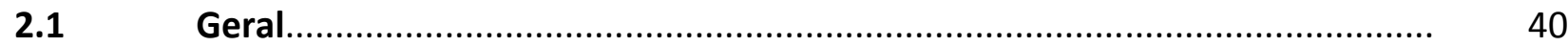

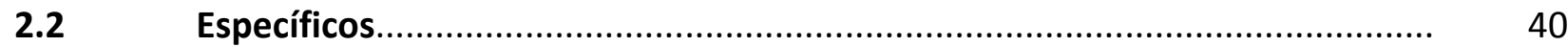

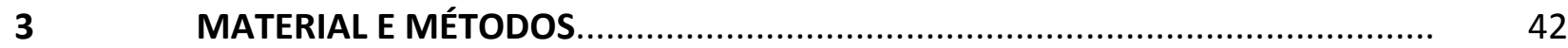

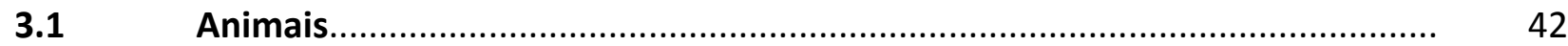

3.2 Confeç̧ão da biomembrana de quitosana-alginato...................................... 42

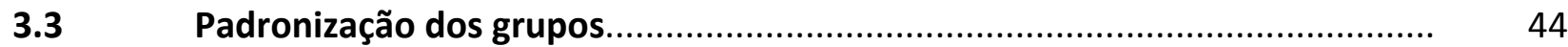

3.4 Procedimento cirúrgico: úlceras cutâneas dorsais..........................................

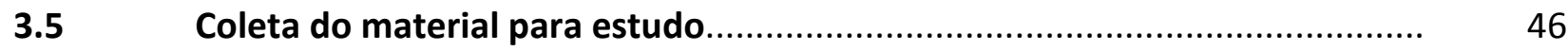

3.6 Avaliação do índice de cicatrização das úlceras pelo ImageJ......................... $\quad 47$

Estudo histológico (histomorfometria)......................................................... 
3.7.1 Avaliação quantitativa por imagem quanto ao infiltrado inflamatório, angiogênese e fibroplasia................................................................................ 48

3.7.2 Avaliação quantitativa por imagem quanto à colagênese...............................

$3.8 \quad$ Dosagem da enzima mieloperoxidase (MPO)............................................ 50

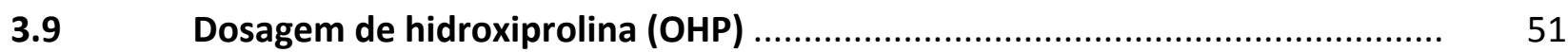

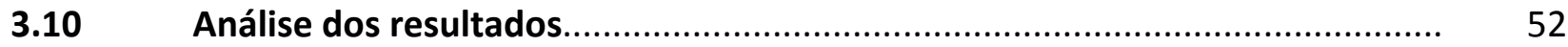

$4 \quad$ RESULTADOS

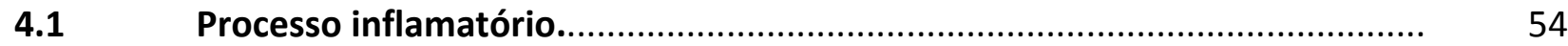

4.1.1 Avaliação do infiltrado inflamatório total......................................................

4.1.2 Dosagem de mieloperoxidase (MPO)......................................................... 56

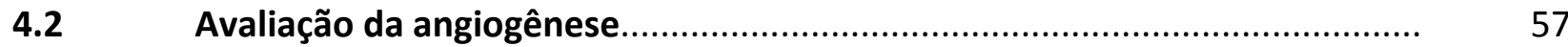

4.3 Avaliação da fibroplasia..................................................................................

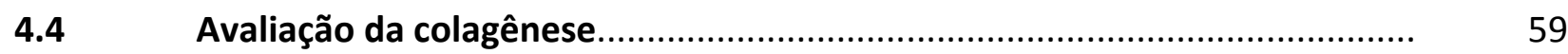

4.4.1 Avaliação histológica por análise de imagem.............................................. 59

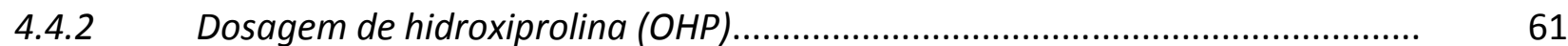

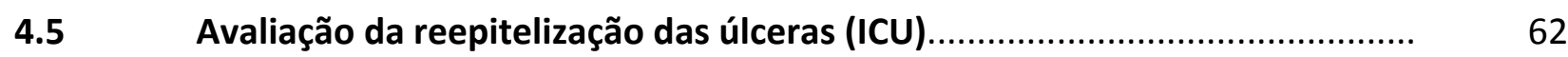

$5 \quad$ DISCUSSÃO

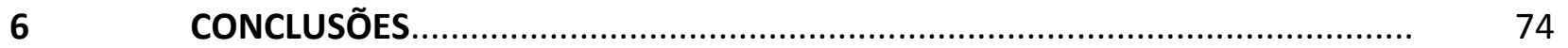

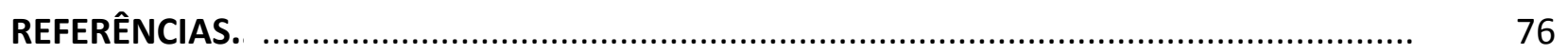




\subsection{Morfofisiologia da pele}

A pele é o maior órgão do corpo humano atingindo até $10 \%$ da massa corporal total. Em adultos, a área total pode chegar de 1,5 a 2,0 $\mathrm{m}^{2}$ e pesar de 8 a $10 \mathrm{~kg}$. É importante manter sua integridade física, pois ela atua como uma barreira mecanicamente flexível, atuando como a primeira linha de defesa contra infecção de microorganismos e toxinas do meio externo. Além de ser um órgão sensorial especializado, o tecido cutâneo desempenha várias funções como proteção contra raios ultravioleta (UV), prevenção contra desidratação, termo-regulação, absorção, vigilância imunológica, cicatrização entre outras (CLARK; GHOSH; TONNESEN, 2007; EHRENREICH; RUSZCZAK, 2006; GÁL et al., 2011; JUNQUEIRA; CARNEIRO, 2004; THEORET, 2009).

A pele consiste em duas camadas distintas: a epiderme, de origem ectodérmica, composta por queratinócitos, e a derme, de origem mesodérmica, uma porção conjuntiva abaixo da epiderme formada por uma associação complexa de fibroblastos e matriz extracelular (MEC), onde se encontram os apêndices (pelos, glândulas sudoríparas e sebáceas) e estruturas como vasos sanguíneos e fibras nervosas. Em continuidade da derme se situa a hipoderme, também de origem mesodérmica, uma frouxa conectiva camada de tecido adiposo que, embora não faça parte da pele, atua como suporte e união dos tecidos e órgãos adjacentes (EHRENREICH; RUSZCZAK, 2006; GOSAIN; DIPIETRO, 2004; JUNQUEIRA; CARNEIRO, 2004).

\subsubsection{Epiderme}

É a camada mais externa da pele composta por células epiteliais limitadas pelo contato com a membrana basal, estrutura que separa a derme da epiderme. É constituída por um epitélio estratificado queratinizado que funciona como uma barreira contra a entrada de água e microorganismos (JUNQUEIRA; CARNEIRO, 2004; PAUL; SHARMA, 2004).

A epiderme é composta por células especializadas como os queratinócitos, células responsáveis pela produção da queratina, uma forte e estrutural proteína, os melanócitos, células responsáveis pela produção da melanina, pigmento da pele que age como protetor natural contra os efeitos nocivos de raios UV, transferida progressivamente para os queratinócitos. Há também as células de Langerhans que atuam na resposta imunológica e 
as células de Merkel que são mecanoreceptores (EHRENREICH; RUSZCZAK, 2006; JUNQUEIRA; CARNEIRO, 2004; WATT, 1988).

A estratificação da epiderme contém cinco camadas: basal, espinhosa, granulosa, lúcida e córnea. A camada basal é a mais profunda, localizada na junção dermo-epidérmica. É também denominada camada germinativa, pois é onde os queratinócitos têm maior potencial mitótico e auxiliados pela camada espinhosa mantém uma contínua renovação da epiderme. A camada granulosa é responsável pela síntese de lipídios armazenados em corpos lamelares e excretados com a finalidade de serem incorporados na camada córnea, tornando a pele impermeável a água e impedindo a desidratação. A camada lúcida é formada por células achatadas e está presente somente em regiões do corpo onde a epiderme é mais espessa, como a planta dos pés e a palma da mão. A camada córnea, a mais superficial, apresenta células mortas com citoplasma repleto de queratina (corneócitos) (ELIAS; MENON, 1991; HOUBEN; DE PAEPE; ROGIERS, 2007; JUNQUEIRA; CARNEIRO, 2004; KIM; YUN; CHO, 2011).

Na diferenciação da epiderme, os queratinócitos deixam a camada basal e movem-se em direção a superfície pela camada espinhosa e granulosa em direção a camada córnea. Neste processo conhecido como diferenciação terminal, os queratinócitos perdem o potencial mitótico e sofrem modificações morfológicas e bioquímicas importantes e transformam-se em estruturas multilamelares de corneócitos anucleados envoltos por matriz extracelular lipídica, formando uma poderosa barreira contra insultos do meio externo (CANDI; SCHMIDT; MELINO, 2005; ELIAS, 2007; KIM; YUN; CHO, 2011; REHDER et al., 2004).

\subsubsection{Derme}

É a parte mais espessa da pele, formada por um tecido conjuntivo composto por colágeno, fibras elásticas e glicosaminoglicanas (GAGs), produzidos por fibroblastos dermais, conferindo estrutura, apoio, consistência física e elasticidade a pele. É generosamente vascularizada e inervada, totalmente invadida por folículos pilosos e glândulas (sebáceas e sudoríparas) que se estendem até a epiderme. A derme é também responsável pela nutrição da epiderme por meio da difusão de pequenas moléculas (EHRENREICH; RUSZCZAK, 2006; 
HUANG; REN; QIN, 1998; JUNQUEIRA; CARNEIRO, 2004; PAUL; SHARMA, 2004; THEORET, 2009).

A derme é dividida em duas camadas, a papilar e a reticular. A camada papilar é constituída por um tecido conjuntivo frouxo (fibroblastos e delgadas fibras colágenas e elásticas), apresentam saliências conhecidas como papilas dérmicas, mantendo íntimo contato com a epiderme. A camada reticular é mais espessa e constituída por um tecido conjuntivo denso (fibroblastos e espessos feixes de fibras colágenas e elásticas) (EHRENREICH; RUSZCZAK, 2006; GOSAIN; DIPIETRO, 2004; JUNQUEIRA; CARNEIRO, 2004;).

Os fibroblastos são células alongadas com formato fusiforme, responsáveis pela síntese da MEC (colágeno tipo I e tipo III, elastina, glicosaminoglicanas, fibronectinas), contribuem para formação da membrana basal (laminina e colágeno tipo IV), fonte de proteinases como as matriz metaloproteinases (MMPs), regulação da diferenciação epitelial, secreção de fatores de crescimento, envolvimento na reparação tecidual, contração na cicatrização, entre outros (CHANG et al., 2002; GOSAIN; DIPIETRO, 2004; PARSONAGE et al., 2005; RODEMANN; MULLER, 1991; SIMIAN et al., 2001; TOMASEK et al., 2002; WISEMAN; WERB, 2002).

\subsubsection{Hipoderme}

A hipoderme ou tecido subcutâneo é a camada mais profunda da pele. Essencialmente é formada por tecido conjuntivo frouxo, composta por células que armazenam gordura, bem vascularizada e responsável basicamente pelo isolamento térmico e absorção de choques mecânicos (JUNQUEIRA; CARNEIRO, 2004; PAUL E SHARMA, 2004).

\section{2 Úlceras cutâneas}

Úlceras cutâneas são definidas como um rompimento celular da continuidade anatômica da pele (envolvendo epiderme e derme) e de sua funcionalidade. Podem ser uma simples lesão na integridade do tecido cutâneo (epiderme e derme) ou alcançar regiões mais profundas (hipoderme, músculos e ossos), expondo as células e tecidos ao meio externo (EHRENREICH; RUSZCZAK, 2006; HENG, 2011; ROBSON; STEED; FRANZ, 2001; SCHMIDT et al., 
2009). Podem ser caracterizadas por sua profundidade, tais como, espessura parcial (derme incompleta) ou úlceras de espessura total (derme completa, podendo atingir o tecido subcutâneo) (MANDELBAUM; DI SANTIS; MANDELBAUM, 2003).

As úlceras constituem um dos principais problemas de saúde pública. Algumas são de difícil cicatrização devido a diversos fatores intrínsecos e extrínsecos (FALANGA, 2005), principalmente quando na fase crônica, agravando ainda mais a doença e diminuindo a qualidade de vida dessas pessoas (GARY-SIBBALD, WOO, 2008).

As úlceras de espessura parcial ocorrem após procedimentos dermatológicos cirúrgicos como a dermoabrasão e peelings químicos, ou causadas por traumatismo. Neste caso, a reparação acontece apenas por meio da reepitelização, resultando em uma cicatriz praticamente imperceptível (MANDELBAUM; DI SANTIS; MANDELBAUM, 2003). As úlceras de espessura total necessitam, além da reepitelização, da formação um tecido de granulação para restaurar o tecido perdido e a cicatriz formada torna-se perceptível e muitas vezes pronunciada (FAZIO; ZITELLI; GOSLEN, 2000; MANDELBAUM; DI SANTIS; MANDELBAUM, 2003).

\subsection{1 Úlceras cutâneas agudas e crônicas}

O tempo é um importante fator na manutenção da lesão e para o processo cicatricial. Deste modo, as úlceras podem ser clinicamente divididas em úlceras agudas e crônicas. As úlceras agudas são definidas quando há um reparo tecidual ordenado e oportuno, seguindo o processo para a restauração anatômica e funcional da pele. O tempo da cicatrização geralmente varia de 5 a 10 dias, podendo chegar até 30 dias (VELNAR; BAILEY; SMRKOLJ, 2009). São de origem traumática ou devido a processos cirúrgicos que, de modo geral, envolve remoção de um tecido conjuntivo frouxo, onde não há presença de contaminações e complicações com o paciente (LAZARUS et al., 1994; ROBSON; STEED; FRANZ, 2001; VELNAR; BAILEY; SMRKOLJ, 2009).

Embora o tempo não esteja claramente definido, úlceras crônicas são aquelas cuja cicatrização não ocorre em um tempo esperado de até 6 semanas (RONDÁN-MARíM et al., 2009) ou de 8 a 12 semanas, sem qualquer sinal de cicatrização (WHITNEY, 2005). O tempo para uma úlcera crônica reepitelizar completamente é significantemente maior e, em alguns casos, a úlcera tem sua área aumentada, principalmente devido ao ambiente altamente rico 
em proteases, permanecem em um estado inflamatório persistente. Deste modo, o reparo tecidual é incompleto, atrasado, não ordenado e resulta em uma pobre restauração anatômica e funcional (MENKE et al., 2007; STOJADINOVIC et al., 2008).

As úlceras crônicas são geralmente originadas por comprometimento vascular, danos repetitivos ao tecido e infecções, sendo as causas mais comuns as que incluem as úlceras venosas, arteriais, neuropáticas, queimaduras e úlceras por pressão (BELLO; PHILLIPS, 2000; KOMARCEVIC, 2000; LAZARUS et al., 1994; MENKE et al., 2007; STOJADINOVIC et al., 2008; VANWIJCK, 2001).

O estímulo inflamatório persistente está relacionado às complicações que incluem hipóxia tecidual, necrose, exsudatos e infecções bacterianas. O contínuo estado inflamatório da úlcera cria inúmeras respostas teciduais que associadas prejudicam a cicatrização. Alta atividade mitótica e o delicado equilíbrio entre citocinas pró-inflamatórias, quimiocinas, proteases e inibidores são ausentes nas úlceras crônicas. Os neutrófilos estão presentes em todo processo e, consequentemente, há uma alta concentração de enzimas degradativas liberadas, como as matrizes metaloproteinases (MMPs), que quando não inibidas por inibidores naturais (TIMPs), resultam em degradação da MEC, migração celular prejudicada, redução de fibroblastos e da síntese de colágeno (LOBMANN et al., 2002; LOBMANN; SCHULTZ; LEHNERT, 2005; MAST; SCHULTZ, 1996; MENKE et al., 2007; STOJADINOVIC et al., 2008; VELNAR; BAILEY; SMRKOLJ, 2009).

A complexidade do processo cicatricial é relacionada à patogênese das úlceras, sua extensão, características físicas e funcionais dos tecidos envolvidos. Muitas são as condições que tornam este processo de difícil resolução, impedindo ou retardando uma completa cicatrização (BROUGHTON II; JANIS; ATTINGER, 2006; KUMAR; ABBAS; FAUSTO, 2005).

O aumento da expectativa de vida e o rápido incremento da população idosa têm sido apontados como determinantes sociais da crescente prevalência de condições crônicas de saúde. Neste contexto, as úlceras cutâneas assumem importância, visto que podem estar relacionadas a doenças crônico-degenerativas associadas à idade, alimentação, doenças cardiovasculares, diabetes mellitus e artrite reumatóide. Projeções publicadas pela Organização Mundial de Saúde (OMS) estimam que a população idosa aumente cerca de sete a oito vezes até o ano 2025 (LIMA E COSTA et al., 2000).

Nos EUA, aproximadamente 600.000 pacientes têm úlceras venosas, com custo médio de dez mil dólares por paciente, enquanto outros 1,4 milhões têm úlceras por 
pressão. O custo total do tratamento para estes dois grupos tem sido estimado em 8 bilhões de dólares anualmente (CLARK; GHOSH; TONNESEN, 2007). Úlceras que não cicatrizam, principalmente em pacientes idosos, podem tornar-se crônicas por anos e levar estes pacientes a óbito (JAUL, 2009; MENKE et al., 2007).

Estudos realizados na União Européia têm estimado uma prevalência para úlceras de pé e perna de 1,48/1000 habitantes e com o avanço da idade, estes números aumentam (36/1000 habitantes com mais de 65 anos de idade). A prevalência anual de úlceras venosas de perna tem sido estimada em 1,69\% para indivíduos com 65 anos de idade ou mais (HOWELL-JONES et al., 2005).

Tais resultados evidenciam a dificuldade da doença úlcera cutânea para os pacientes, tendo em vista os aspectos socioeconômicos e psicológicos. Um paciente com uma úlcera que não cicatriza tem diminuição da qualidade de vida devido ao desconforto, mau odor, presença de secreção, além de dano à imagem corporal, a qual resulta em isolamento social (JAUL, 2009). Outras complicações de úlceras crônicas incluem limitações funcionais (como dificuldade de locomoção), dor crônica, infecções (formação de abscessos, osteomielite e mesmo sepse) e amputação (MENKE et al., 2007).

Nos últimos séculos e nas décadas recentes inúmeros avanços trouxeram mudanças significantes no conhecimento científico sobre o processo cicatricial, que influenciaram as abordagens atualmente aceitas no tratamento de úlceras cutâneas (SHAI; MAIBACH, 2005).

\subsection{Cicatrização}

A cicatrização é um processo biológico complexo, multifatorial e contínuo, dividido em cinco fases distintas didaticamente, porém sobrepostas: lesão, coagulação, inflamação, formação e remodelagem teciduais. Em diferentes regiões de uma mesma úlcera, diferentes fases da cicatrização podem estar ocorrendo concomitantemente (BROUGHTON II; JANIS; ATTINGER, 2006; CAMPOS; GROTH; BRANCO, 2008; MENKE et al., 2008; STRONCEK; BELL; REICHERT, 2009).

Há participação de elementos celulares e/ou extracelulares específicos como citocinas e fatores de crescimento, que agem como substâncias sinalizadoras, supressoras e estimuladoras com função de orquestrar e manter as funções biofisiológicas de cada fase, 
ocorrendo de forma sequencial em todo o processo, em uma intensidade regulada (GOSAIN; DIPIETRO, 2004; MATHIEU; LINKE; WATTEL, 2006; STOJADINOVIC et al., 2008).

A perda da integridade da pele pode resultar em um grande desequilíbrio fisiológico que pode ocasionar desabilidade significante ao paciente ou mesmo óbito (CLARK; GHOSH; TONNESEN, 2007). Quando uma lesão ocorre com extravasamento de sangue, a resposta imediata é alcançar a hemostasia tecidual e criar um suporte para o influxo celular. O reparo tecidual se inicia com a proliferação e crescimento de células da derme (fibroblastos e células estromais) e da epiderme (queratinócitos) (STOJADINOVIC et al., 2008).

\subsubsection{Coagulação}

Imediatamente após a lesão, onde há o rompimento da solução de continuidade tecidual de uma região vascularizada, ocorre o extravasamento de sangue que preenche a área lesada com plasma e elementos celulares (plaquetas). As plaquetas, juntamente com a fibrina, iniciam a coagulação sanguínea imediatamente após a lesão com ativação da cascata da coagulação, aumentando a permeabilidade vascular e liberando proteínas plasmáticas (fibrinogênio e fibronectina), aminas vasoativas e outros mediadores (BEANES et al., 2003; KARUKONDA et al., 2000).

O principal objetivo desta fase é impedir a perda sanguínea, proteger o sistema vascular para manter as funções dos órgãos vitais (BROUGHTON II; JANIS; ATTINGER, 2006; VELNAR; BAILEY; SMRKOL, 2009). Para isso, há formação de um coágulo plaquetário que servirá também como uma matriz temporária para o recrutamento de células nas fases seguintes da cicatrização (ROBSON; STEED; FRANZ, 2001; STOJADINOVIC et al., 2008).

Devido ao mecanismo de reflexo neural, vasos lesados constringem rapidamente devido à contração de células da musculatura lisa de arteríolas de calibre até $0,5 \mathrm{~cm}$ de diâmetro. Entretanto, a constrição vascular pelo tono muscular liso somente acontece por alguns segundos, pois a hipóxia e acidez na parede da úlcera causa passivo relaxamento celular e o extravasamento sanguíneo continua (LAWRENCE, 1998; STRECKER-MCGRAW; JONES; BAER, 2007; VELNAR; BAILEY; SMRKOLJ, 2009). Potentes vasoconstrictores como tromboxano A2 e prostaglandinas-2 são liberados para evitar a perda excessiva de sangue (CAMPOS; GROTH; BRANCO, 2008). 
O processo de hemostasia continua com ativação da cascata de coagulação objetivando formar o coágulo sanguíneo. As plaquetas e outros componentes do sangue entram em contato com o colágeno (receptores glicoprotéicos específicos GPIb/IX/V) e componentes da matriz extracelular do tecido ao redor. Esse contato das plaquetas aciona a liberação de fatores de coagulação e a formação do coágulo composto de plaquetas, fibrina e fibronectina. Este tampão plaquetário formado não apenas leva à hemostasia, como também desempenha função de matriz provisória para a migração celular (monócitos, neutrófilos, fibroblastos e células endoteliais) no local da lesão (BEANES et al., 2003; BROUGHTON II; JANIS; ATTINGER, 2006; CAMPOS; GROTH; BRANCO, 2008; LAWRENCE, 1998; RUGGERI, 2002; VELNAR; BAILEY; SMRKOL, 2009).

A adesão e agregação plaquetária funcionam como ativadores da liberação de fatores de coagulação. Esses fatores, além de acionar a polimerização da fibrina, resultado da ação de conversão da trombina em fibrinogênio no coágulo plaquetário, são também responsáveis pela degranulação e liberação de citocinas pró-inflamatórias, além de diversos fatores de crescimento, como fator de crescimento derivado de plaquetas (PDGF), fator de transformação de crescimento beta 1 e alfa (TGF- $\beta 1$ e TGF- $\alpha$ ), fator de crescimento de queratinócitos (KGF-2), fator de crescimento de fibroblastos (FGF) e fator de crescimento endotelial (EGF) (BEANES et al., 2003; BROUGHTON II; JANIS; ATTINGER, 2006; CAMPOS; GROTH; BRANCO, 2008; LAWRENCE, 1998; STANDEVEN; ARIENS; GRANT, 2005).

Esses fatores atuam ativando e atraindo células inflamatórias, endoteliais e fibroblastos para a área da lesão. O coágulo formado serve como um reservatório de fatores de crescimento que irão atrair quimiotaticamente células para a fase inflamatória. As plaquetas também liberam aminas vasoativas, como a serotonina, estocadas em densos corpos plaquetários que causam vasodilatação e aumento da permeabilidade vascular para o influxo celular para as fases subsequentes da cicatrização (CAMPOS; GROTH; BRANCO, 2008; LAWRENCE, 1998; RICHARDSON, 2004; STRONCEK; BELL; REICHERT, 2009).

Qualquer processo que remova o tampão de fibrina da úlcera leva à interrupção da formação da matriz temporária e consequentemente a um atraso na cicatrização (BEANES et al., 2003; FUKAl et al., 1991). 


\subsubsection{Inflamação}

Na fase seguinte, inflamação, uma resposta celular e humoral acontece com objetivo de criar uma barreira imunológica contra microrganismos invasores. A fase inflamatória é caracterizada pelos sinais típicos do processo inflamatório localizado, como dor, rubor, calor e edema, resultado da vasodilatação e da permeabilidade capilar aumentada (BAUM; ARPEY, 2005; MONACO; LAWRENCE, 2003). As principais células envolvidas são os neutrófilos e os macrófagos, com função de desbridamento e preparar o local afetado para o crescimento do novo tecido (ABREU; MARQUES, 2005). A resposta inflamatória inicia-se no final da fase de coagulação, onde fatores de crescimento e citocinas são liberados no local da úlcera para que neutrófilos sejam quimiotaticamente atraídos para a lesão (BROUGHTON II; JANIS; ATTINGER, 2006; HART, 2002).

Alterações na regulação de moléculas de adesão dos leucócitos promovem o processo de marginação na corrente sanguínea. Neste processo, a aderência às células endoteliais faz-se por meio do receptor dos leucócitos PSGL-1 que se ligam a P-selectinas expressas em plaquetas e células endoteliais. Como essas ligações são fracas, os leucócitos rolam na superfície do endotélio puxados pelo fluxo sanguíneo. O fator IV de plaquetas e o fator de ativação de plaquetas aumentam a expressão de CD8/CD11b, integrinas na superfície de neutrófilos que facilitam a transmigração de leucócitos pelo endotélio, um processo chamado diapedese (HART, 2002; HENG, 2011; MONACO; LAWRENCE, 2003; YAGER; NWOMEH, 1999).

Durante o rolamento, neutrófilos são ativados por interleucina-8 (IL-8) e proteína inflamatória de macrófagos (MIP-1ß) liberados por células endoteliais. Receptores de neutrófilos ligados a quimiocinas ativam integrinas $\beta 2$, intensificando ainda mais a adesão (SPRINGER, 1994; STRONCEK; BELL; REICHERT, 2009).

Os neutrófilos, leucócitos mais comuns, são as menores células inflamatórias e a primeira linha de defesa nesta fase. São importantes pela sua atividade microbicida, principalmente pela liberação de enzimas proteolíticas tal como a mieloperoxidase (SWAIN; ROHN; QUINN, 2002; STRONCEK; BELL; REICHERT, 2009), além de espécies reativas derivadas do oxigênio (ROS's) e óxido nítrico (NO) (BROUGHTON II; JANIS; ATTINGER, 2006; FIERRO et al., 1996; FIERRO et al., 1999). 
Os neutrófilos, ao chegar à úlcera por meio do TGF- $\beta$, fator de necrose tumoral (TNF), interleucina (IL-1 $\beta$ ), componentes complemento (C3a e C5a) e peptídeos produzidos pelas próprias bactérias, iniciam a atividade de fagocitose de partículas estranhas e o desbridamento do tecido lesado por meio de enzimas proteolíticas (BROUGHTON II; JANIS; ATTINGER, 2006; CAMPOS; GROTH; BRANCO, 2008; HENG, 2011; ROBSON; STEED; FRANZ, 2001; VELNAR; BAILEY; SMRKOLJ, 2009). As espécies reativas destroem agentes infecciosos, além de possíveis células hospedeiras, limpando a área da úlcera para impedir contaminações (GUO; DIPIETRO, 2010; MARTIN; LEIBOVICH, 2005).

Uma vez que os patógenos são removidos, a atividade neutrofílica diminui gradualmente e os neutrófilos entram em processo de apoptose. Deste modo, a eliminação neutrofílica não cria danos ao tecido, evitando que a resposta inflamatória seja potencializada (FRADE, 2003; HART, 2002; STRONCEK; BELL; REICHERT, 2009). Os corpos apoptóticos são fagocitados por macrófagos, dando seguimento à fase inflamatória (BROUGHTON II; JANIS; ATTINGER, 2006; STRONCEK; BELL; REICHERT, 2009).

Os macrófagos chegam ao local da lesão e continuam o processo de fagocitose. Originalmente, monócitos são recrutados da corrente sanguínea e ao chegar à úlcera sofrem alterações fenotípicas, diferenciando em macrófagos. São atraídos por várias quimiocinas, como a proteína-1 quimiotática de monócito (MCP-1), MIP-1 $\alpha$ e MIP-1 $\beta$, fatores de coagulação, componentes do sistema complemento, fibronectina, citocinas (PDGF, TGF- $\beta$, fator IV de plaquetas), elastina e colágeno provenientes da MEC destruída na lesão (FUKAI et al., 1991; HART, 2002; PIERCE et al., 1991; RAMASASTRY, 2005; STRONCEK; BELL; REICHERT, 2009).

Em estudos onde os neutrófilos foram inibidos, observou-se que o processo de reparo não foi prejudicado. O mesmo não aconteceu quando os macrófagos foram removidos, pois houve limpeza limitada do tecido necrótico no local da lesão, resultando em processo de cicatrização prolongado e demora da proliferação de fibroblastos com subsequente fibrose da úlcera. (BAUM; ARPEY, 2005; DIEGELMANN; EVANS, 2004; GURTNER et al., 2008; LEIBOVICH; ROSS, 1975; STRONCEK; BELL; REICHERT, 2009).

Além de fagocitar restos celulares, células apoptóticas e neutrófilos senescentes, os macrófagos têm papel crucial no processo de cicatrização. Eles atuam como células reguladoras e potente reservatório de fatores de crescimento tecidual (TGF- $\beta$, TGF- $\alpha$, fatores angiogênicos, EGF e FGF) e citocinas pró-inflamatórias (TNF- $\alpha$ e IL-1ß), além de liberarem 
MMPs, colagenases e elastases para quebra do conteúdo extracelular remanescente (BROUGHTON II; JANIS; ATTINGER, 2006; CAMPOS; GROTH; BRANCO, 2008; DIEGELMANN; EVANS, 2004; HENG, 2011; MOSSER; EDWARDS, 2008; RAMASASTRY, 2005).

Os mastócitos auxiliam na resposta inflamatória liberando histamina e serotonina para aumentar a permeabilidade dos vasos sanguíneos e promover a migração dos macrófagos (BRADDING; WALLS; CHURCH, 1995; STRONCEK; BELL; REICHERT, 2009). Os linfócitos atraídos por IL-1 $\beta$ são as últimas células a participar da fase inflamatória, porém seu papel ainda não foi totalmente elucidado (BROUGHTON II; JANIS; ATTINGER, 2006; GUO; DIPIETRO, 2010; HART, 2002;).

Os macrófagos, além de auxiliarem na limpeza da úlcera, atuam na transição para a fase seguinte da cicatrização, pois estimulam a proliferação de queratinócitos, fibroblastos e o processo de angiogênese, dando início da fase de formação proliferativa (GUO; DIPIETRO, 2010; MESZAROS; REICHNER; ALBINA, 2000; MOSSER; EDWARDS, 2008).

\subsubsection{Formação tecidual}

A fase de formação tecidual constitui-se no restabelecimento da integridade da epiderme e da derme. É caracterizada por uma intensa proliferação e migração celular, brotamento de capilares e síntese de uma nova MEC para preencher o tecido danificado após o desbridamento feito na fase inflamatória (GUO; DIPIETRO, 2010; STRONCEK; BELL; REICHERT, 2009; VELNAR; BAILEY; SMRKOL, 2009). Esta fase é caracterizada pela formação do tecido de granulação, síntese de colágeno pelos fibroblastos, angiogênese e reepitelização (BROUGHTON II; JANIS; ATTINGER, 2006; CAMPOS; GROTH; BRANCO, 2008).

O tecido de granulação é assim chamado pelo aspecto granular gerado pelos capilares neoformados no local da lesão, presença de células inflamatórias (principalmente macrófagos), células endoteliais, fibroblastos e miofibroblastos em uma matriz frouxamente agregada, que precede o desenvolvimento do tecido cicatricial maduro (BAUM; ARPEY, 2005; BEANES et al., 2003; CLARK; GHOSH; TONNESEN, 2007). 


\subsubsection{Fibroblastos e síntese de colágeno}

No momento da lesão, fibroblastos do tecido circunjacente são estimulados à proliferação. Alcançada a hemostasia e livre de infecção, os fibroblastos são atraídos à úlcera por meio da ação de TGF- $\beta$ e PDGF, liberados por células inflamatórias e plaquetas. Uma vez no local da lesão, os fibroblastos continuam a proliferação e sintetizam elementos da nova matriz como, proteoglicanas, glicosaminoglicanas e colágeno, principais componentes da MEC, que são depositados no local para substituir a matriz provisória inicial composta por fibrina (CAMPOS; GROTH; BRANCO, 2008; GUO; DIPIETRO, 2010; RAMASASTRY, 2005; VELNAR; BAILEY; SMRKOLJ, 2009).

Neste estágio da cicatrização, há uma concentração de fibroblastos no tecido de granulação em desenvolvimento devido à ação de FGF, TGF- $\beta$ e PDGF. O FGF estimula a proliferação celular. O TGF- $\beta$ estimula a produção de colágeno (posterior síntese de colágeno tipo I) pelos fibroblastos e também sua diferenciação em miofibroblastos. O PDGF estimula a proliferação e ativação dos fibroblastos. Os fibroblastos secretam FGF, TGF- $\beta$ e PDGF para a própria manutenção, além do fator de crescimento semelhante à insulina 1 (IGF-1) e fator de crescimento para queratinócitos (KGF) (BROUGHTON II; JANIS; ATTINGER, 2006; CAMPOS; GROTH; BRANCO, 2008).

O colágeno é a principal proteína do tecido conjuntivo. Tem estrutura helicoidal composta por glicina, prolina e hidroxiprolina. Diferenças em sua estrutura química determinam seu papel biológico. O tipo I é a mais frequente forma encontrada, presente principalmente em ossos e tendões. O tipo III é mais fino, imaturo e desorganizado, está presente em vasos sanguíneos, fáscia e na derme, juntamente com o tipo I (ROBSON; STEED; FRANZ, 2001).

Em um tecido intacto, encontra-se $80 \%$ do tipo I e $20 \%$ do tipo III. Já em um tecido de granulação, encontra-se $40 \%$ do tipo III. Sintetizado pelos fibroblastos é importante em todas as fases da cicatrização, pois proporcionam integridade e força para os tecidos, além de um importante papel no remodelamento tecidual (BAUM; ARPEY, 2005; CAMPOS; GROTH; BRANCO, 2008; ROBSON; STEED; FRANZ, 2001;).

A molécula de hidroxiprolina tem papel muito importante no colágeno uma vez que proporciona a conformação helicoidal estável à proteína. Quando ausente, por exemplo, em condições como falta de vitamina $C$, o colágeno tem sua estrutura alterada e pode sofrer 
desnaturação mais facilmente. O colágeno liberado no espaço extracelular passa pela clivagem dos peptídeos terminais N e C e a enzima lisil-oxidase proporciona a formação de ligações (crosslinks) mais estáveis. Conforme o colágeno torna-se maduro, mais ligações intra e intercelulares ocorrem nestas moléculas. Esta etapa importante de cross-linking proporciona, com o passar do tempo, força e estabilidade ao colágeno (CORSETTI et al., 2009; DIEGELMANN; EVANS, 2004; DOUGHTY; SPARKS-DeFRIESE, 2012).

No rompimento de tecidos, o colágeno é necessário para reparar a perda e restaurar a estrutura normal. Se um excesso de colágeno for depositado no local da lesão, a estrutura anatômica normal da pele será perdida e ocorrerá fibrose. Por outro lado, se uma quantidade insuficiente for depositada, a úlcera, e consequentemente a cicatriz, serão frágeis. A síntese adequada de colágeno é um processo fundamental para a cicatrização das úlceras cutâneas (CORSETTI et al., 2009; DIEGELMANN; EVANS, 2004; MONACO; LAWRENCE, 2003).

Após abundante síntese e deposição de MEC, os fibroblastos, por ação do TGF- $\beta$, sofrem alterações fenotípicas e transformam-se em miofibroblastos. Neste estágio, eles expressam largos filamentos de actina (assemelham-se à musculatura lisa) abaixo da membrana plasmática. Ativamente estendem pseudópodes que se prendem firmemente no colágeno da MEC para fazer fortes movimentos de retração celular. A contração da úlcera é um evento importante para o processo de reparo na tentativa de aproximar as bordas da lesão. Por fim, o excesso de fibroblastos e miofibroblastos são eliminados por apoptose (BAUM; ARPEY, 2005; GOLDMAN, 2004; RAMASASTRY, 2005).

\subsubsection{Angiogênese}

Células endoteliais residentes ao redor da úlcera formam novos capilares quando estes são destruídos. Degradam e invadem a matriz provisória da lesão e se conectam a outras células que por meio de brotamento originam novos vasos. Deste modo, conseguem formar uma rede vascular mínima que permite a circulação sanguínea e assim nutrir as células que chegam ao local da lesão (BARANOSKI; AYELLO, 2004).

As células endoteliais também são responsáveis pela liberação de fatores angiogênicos, VEGF (fator de crescimento endotelial vascular), PDGF, TGF- $\alpha$ e TGF- $\beta$. Em hipóxia, moléculas são secretadas por células parenquimatosas ao redor da lesão para 
promover a proliferação e crescimento de células endoteliais. Angiostatina e esteróides são fatores inibitórios que mantém um equilíbrio adequado na proliferação de células endoteliais, controlando a taxa de mitose e a liberação dos demais fatores. (FERRARA, 2000; OIKE et al., 2004; VELNAR; BAILEY; SMRKOL, 2009; ZHANG et al., 1997).

Macrófagos, proliferação de fibroblastos e a vascularização do tecido juntamente com matriz de colágeno, fibrinogênio, fibronectina e ácido hialurônico constituem o tecido de granulação agudo que substitui a matriz provisória de fibrina formada na fase inflamatória. Com o acúmulo de colágeno, há uma queda na concentração de vasos sanguíneos e o tecido de granulação começa a maturar para a formação de uma cicatriz (BAUM; ARPEY, 2005; MOON et al., 2005, VELNAR; BAILEY; SMRKOL, 2009).

Assim, macrófagos, fibroblastos e vasos sanguíneos são elementos importantes que atuam de maneira interdependente no interior da lesão durante o processo cicatricial. Os macrófagos estimulam a fibroplasia e a angiogênese por serem uma fonte contínua de liberação de fatores de crescimento, enquanto os fibroblastos atuam na construção da nova matriz extracelular, produzindo colágeno, glicosaminoglicanas e proteoglicanas, que dará suporte para a chegada de células de reparo tecidual. Vasos sanguíneos neoformados tem a função do transporte de oxigênio e nutrientes para o metabolismo celular acentuado. Assim, o processo de granulação tecidual ocorre como consequência direta da ativação dos mecanismos de fibroplasia e angiogênese (ARNOLD; WEST, 1991; CAMPOS; GROTH; BRANCO, 2008; GOSAIN; DIPIETRO, 2004).

\subsubsection{Reepitelização}

A reepitelização é o processo de restauração da epiderme por meio da proliferação e migração de queratinócitos da epiderme circunjacente. Inicia-se logo após o momento da lesão, migrando no sentido das bordas para o centro por intermédio da matriz provisória de fibrina e fibronectina. No momento que as células epiteliais encontram-se, a migração cessa e inicia-se a formação de uma nova membrana basal (LI; CHEN; KIRSNER, 2007; MONACO; LAWRENCE, 2003).

Citocinas inflamatórias, como IL-1 $\beta$ e TNF- $\alpha$ estimulam fibroblastos a sintetizar e secretar KGF-1, KGF-2 e IL-6, os quais estimulam a proliferação, diferenciação e migração de 
queratinócitos (BAUM; ARPEY, 2005; BROUGHTON II; JANIS; ATTINGER, 2006; STOJADINOVIC et al., 2008; STRONCEK; BELL; REICHERT, 2009).

A migração dos queratinócitos e a contração da úlcera resultam na reepitelização da área lesada. O resultado final da fase proliferativa é vitalmente importante para a cicatrização, pois estabelece o suporte necessário para reconstruir o tecido danificado (HARDING; PATEL, 2002; STRONCEK; BELL; REICHERT, 2009).

\subsubsection{Remodelagem Tecidual}

A remodelagem tecidual se caracteriza pela reorganização da matriz extracelular onde a arquitetura da pele é remodelada na tentativa de retorno à estrutura tecidual normal com degradação do colágeno imaturo e instável e formação de um colágeno estável e organizado, por meio da ação das colagenases, metaloproteinases e fatores inibitórios (CAMPOS; GROTH; BRANCO, 2008; GOSAIN; DIPIETRO, 2004). Nesta fase, todos os processos ativados no início da lesão são cessados progressivamente e a população celular (células endoteliais, macrófagos e miofibroblastos) começa a sofrer apoptose, permanecendo apenas grande quantidade de colágeno, elementos da matriz e poucas células (GURTNER et al., 2008).

Em úlceras onde a membrana basal não é afetada, pouca atividade de remodelamento acontece devido à ausência de uma nova MEC sintetizada na fase de proliferação. Deste modo, não há formação de cicatriz após o reparo do tecido. Por outro lado, em lesões onde pelo menos a derme superior é atingida, há intensa formação da MEC e a fase de remodelamento envolve alinhamento e contração das fibras para diminuir o tamanho da úlcera e restabelecer a força tecidual. A recuperação do novo tecido raramente pode ser comparada a um tecido original, pois a nova estrutura é menos organizada, resultando na formação de uma cicatriz (STRONCEK; BELL; REICHERT, 2009).

O remodelamento de uma úlcera aguda é controlado por mecanismos regulatórios que manterão um contínuo equilíbrio delicado entre degradação e síntese de colágeno. As MMPs, produzidas por neutrófilos, macrófagos e principalmente fibroblastos, são responsáveis pela degradação do colágeno. O TGF- $\beta$ é predominantemente o mediador da maturação e remodelamento da úlcera, inibindo a atividade das MMPs por meio da expressão dos TIMPs, pausando a atividade de degradação para que a nova matriz de 
colágeno seja acumulada (GRINELL, 2003; LAWRENCE, DIEGELMANN, 1994; STOJADINOVIC et al., 2008; VELNAR; BAILEY; SMRKOLJ, 2009).

Neste processo de degradação, a matriz extracelular composta por fibronectina, proteoglicanas e principalmente colágeno tipo III é substituída pelo colágeno tipo I, um colágeno mais grosso, forte e bem organizado. Os miofibroblastos permanecentes no tecido, juntamente com as fibras de colágeno, tornam-se orientados paralelamente ao leito da lesão, resultando em uma aparência estriada, diferente do tecido observado na pele intacta (GURTNER et al., 2008; STOJADINOVIC et al., 2008; STRONCEK; BELL; REICHERT, 2009).

O colágeno encontrado no tecido de granulação é bioquimicamente diferente do colágeno da pele intacta. O colágeno do tecido de granulação tem maior hidroxilação e glicosilação dos resíduos de lisina e este aumento da glicosilação está correlacionado com fibras mais finas. O colágeno presente na cicatriz (mesmo após um ano de maturação) nunca será organizado e forte como o colágeno encontrado na pele intacta. Em uma semana, a úlcera tem cerca de $3 \%$ de sua força tensora final, em três semanas cerca de $30 \%$, e em três meses aproximadamente $80 \%$, sendo este o nível mais alto de força tensora que um tecido cicatrizado pode alcançar (BROUGHTON II; JANIS; ATTINGER, 2006; DIEGELMANN; EVANS, 2004; GURTNER et al., 2008; STOJADINOVIC et al., 2008; STRONCEK; BELL; REICHERT, 2009).

Os macrófagos começam a desaparecer junto com a proliferação de fibroblastos e a redução da angiogênese, de forma que a densidade vascular da ferida volte ao normal. O remodelamento tecidual continua por 1 ou 2 anos ou dependendo do paciente e do tipo da úlcera pode permanecer nesta fase ainda mais tempo. Estruturas dérmicas, como folículos pilosos, glândulas sebáceas e sudoríparas, que foram perdidas durante a lesão não são regeneradas. Acredita-se que ao longo desse processo, a ferida ainda sofra outras contrações físicas pelo aparecimento de novos miofibroblastos (BAUM; ARPEY, 2005; CAMPOS; GROTH; BRANCO, 2008; GOSAIN; DIPIETRO, 2004; STRONCEK; BELL; REICHERT, 2009).

Diante dos grandes avanços na compreensão dos fenômenos envolvidos no processo cicatricial, a incidência de úlceras cutâneas de difícil cicatrização ainda se mantém elevada, repercutindo em altos custos e consequências sociais aos pacientes, tornando relevante o estudo científico para melhor compreensão dos fatores envolvidos e novas possibilidades terapêuticas para o tratamento de úlceras cutâneas utilizando principalmente curativos biológicos atóxicos (SEHN et al., 2009). 


\subsection{Tratamento de úlceras}

O tratamento tópico de úlceras consiste em restaurar o ambiente fisiológico no leito da lesão, visando manter uma umidade adequada, controle de temperatura, regulação de $\mathrm{pH}$, controle da carga bacteriana, remoção do tecido não-viável (desbridamento), controle do odor, minimização de dor e proteção da pele na região afetada. Estas condições, uma vez ajustadas, irão contribuir para o reparo e restauração da função tecidual. Nenhum tratamento tópico será eficaz se a condição patológica do paciente não for corrigida (ROLSTAD; BRYANT; NIX, 2012).

Nos últimos séculos e nas décadas recentes inúmeros avanços trouxeram mudanças significantes no conhecimento científico sobre o processo cicatricial, que influenciaram as abordagens atualmente aceitas no tratamento de úlceras cutâneas (SHAI; MAIBACH, 2005).

A terapêutica implica não apenas no conhecimento dos produtos (medicamentos, curativos) utilizados para promover a cicatrização, mas primeiramente no entendimento da fisiopatologia do processo cicatricial, pois a cada estágio do processo de reparo, a úlcera requer condições diferentes para progredir. Nem todos os tratamentos e curativos são indicados ou apropriados para serem usados continuamente até o fechamento da úlcera. A maioria das úlceras requer numerosas modificações conforme suas características se alteram ao longo do seguimento/tratamento. O tratamento deve ser reavaliado e readequado baseado nas características da úlcera e na resposta do paciente (ABREU; MARQUES, 2005; ROLSTAD; BRYANT; NIX, 2012).

Muitos curativos naturais e sintéticos, assim como métodos baseados em fototerapia (LEITE et al 2011, MINATEL et al 2009) têm sido alvos frequentes na busca de estratégias eficazes da estimulação do processo cicatricial, destacando dezenas de curativos impregnados com diferentes substâncias, desde vaselina a fatores de crescimento geneticamente produzidos, disponíveis comercialmente (BROUGHTON II; JANIS; ATTINGER, 2006).

Em 2003 uma pesquisa avaliou que o mercado americano de produtos para o tratamento de úlceras, incluindo curativos biológicos e sintéticos, foi maior que 1,7 bilhões de dólares e estimou um aumento significativo conforme a população envelhece, pois se tornam mais susceptíveis às causas de úlceras crônicas. A qualidade de vida desses indivíduos é extremamente pobre, além do constante gasto financeiro indireto na 
manutenção da lesão, o que torna difícil o acesso ao real custo com úlceras cutâneas com curativos e tratamentos existentes (CLARK; GHOSH; TONNESEN, 2007).

Há várias exigências que necessitam ser cumpridas para a utilização de um novo curativo na cicatrização de úlceras. Dentre eles pode-se citar a capacidade de atuar como barreira contra patógenos do meio externo, isolando o local da lesão, não ser tóxico, manter o ambiente úmido, promover a cicatrização, e ao mesmo tempo manter uma boa troca de gases. Devem ser capazes também de absorver o excesso de exsudato, não se aderir ao leito da lesão, fácil manipulação e baixo custo (WIEGAND; HIPLER, 2010).

Curativos biológicos (biomateriais) produzidos a base de polímeros como a celulose, colágeno, alginato e quitosana, tem a capacidade de envolvimento natural no tecido lesado, assim como no tecido em formação, para promover a cicatrização. Além disso, apresentam propriedades antimicrobianas intrínsecas e distintas possibilidades de ligações para mediadores inflamatórios (citocinas, proteases e radicais livres), cujas concentrações são elevadas em úlceras crônicas de difícil cicatrização (WIEGAND; HIPLER, 2010).

Diversos curativos sintéticos e biológicos têm sido desenvolvidos e caracterizados objetivando proporcionar propriedades ideais para o tratamento de úlceras. Os biomateriais, além dessas propriedades, caracterizam-se por terem origem de produtos renováveis e biodegradáveis (PAUL; SHARMA, 2004; WANG; KHOR; LIM, 2001; WANG et al., 2002; WIEGAND; HIPLER, 2010). São empregados na tentativa de estabelecer um suporte biológico tridimensional saudável, mimetizando uma matriz cutânea original que possibilite a migração, proliferação e uma organização ideal das células no microambiente fisiológico cutâneo alterado (GOMES et al., 2003; SILVA, 2008).

Existe uma grande variedade de curativos em formas de géis, espumas e filmes de diferentes biomateriais. Alguns tiveram bastante êxito, mas ainda não representam um curativo ideal. Neste sentido, intensas pesquisas visam aprimorar a confecção de um curativo biológico ideal para o tratamento de úlceras e queimaduras. Uma biomembrana com boas perspectivas de emprego são as formadas por associações de polímeros de quitosana com polímeros de alginato (HEDLUND, 2002; STASHAK; FARSTVEDT; OTHIC, 2004; WIEGAND; HIPLER, 2010). 


\subsection{Biomembrana de quitosana-alginato}

A quitosana é um biopolímero que tem sido estudada recentemente quando comparada a outros polímeros da literatura. Ao contrário dos polímeros sintéticos, a quitosana tem uma superfície hidrofílica que permite a adesão e crescimento celular (AZEVEDO et al., 2007; GEORGE; ABRAHAM, 2006; LI et al., 2009). É um polissacarídeo atóxico composto por cadeias de $\mathrm{N}$-acetil glicosamina e D-glicosamina, derivado da quitina por meio de desacetilação parcial, formando um polímero linear natural biodegradável e biocompatível. Pode ser facilmente encontrada no exoesqueleto de insetos, nas conchas de crustáceos e na parede celular de fungos (DALLAN, 2005; KHAN; PEH, 2003; WIEGAND; HIPLER, 2010).

Depois da celulose, a quitosana é o polissacarídeo mais abundante encontrado na natureza. Sua biocompatibilidade e diversas outras características fazem deste biopolímero um dos mais investigados nos mais diversos campos da ciência (HEIN et al., 2008). A quitina e a quitosana tem sido amplamente utilizadas nos mais variados campos de trabalho, como por exemplo, no tratamento de água, agricultura, cosméticos, processamento alimentício e biomaterial em estudos farmacêuticos e biotecnológicos (AZEVEDO et al., 2007; GEORGE; ABRAHAM, 2006). Os curativos à base de quitosana podem ser manufaturados de várias formas, incluindo fibras, membranas, esponjas e géis (HEIN et al., 2008; MALAFAYA; SILVA; REIS, 2007; PAUL; SHARMA, 2004; SUZUKI; MIZUSHIMA, 1997; YUDANOVA; RESHETOV, 2006).

Este biopolímero contém muitas funções biológicas. Como curativo pode-se citar propriedades de acelerar o processo de cicatrização de úlceras cutâneas ao ativar macrófagos funcionais, aumentar o número de fibroblastos na área afetada, a diferenciação celular e a reepitelização da pele (HEIN et al., 2008; PAUL; SHARMA, 2004; WANG; KHOR; LIM, 2001;). Destaca-se também a ação antimicrobiana, atuação nas junções epiteliais e na reorganização da histo-arquitetura celular (ALEMDAROGLU et al., 2006; CLASEN; WILHELMS; KULICKE, 2006; SUZUKI; MIZUSHIMA, 1997; PAUL; SHARMA, 2004).

De acordo com estudos encontrados na literatura, percebe-se que este biopolímero torna-se viável à aplicação na cicatrização de feridas de pele. Dentre suas diversas características, destacam-se a capacidade de ser absorvido pelo organismo, atividade 
fungicida, antibacteriana e antitumoral, sendo esta última devido à propriedade de ativar macrófagos (HEIN et al., 2008; MALAFAYA; SILVA; REIS, 2007; RODRIGUES, 2008).

Por ser um material hemostático, a quitosana auxilia no processo de coagulação natural e sua despolimerização libera, a partir de hidrólises, oligômeros de N-acetil- $\beta$-Dglicosamina, um amino-açúcar comum ao organismo que entra na via metabólica inata para ser incorporado em glicoproteínas, responsável por uma rápida proliferação de fibroblastos e uma deposição ordenada do colágeno (HEIN et al., 2008; PAUL; SHARMA, 2004; RODRIGUES, 2008). Os oligômeros oriundos da quitosana estimulam e modulam a síntese do ácido hialurônico natural, o qual tem papel importante na morfogênese e inflamação, promovendo maior motilidade celular, adesão e proliferação (MUZZARELLI, 2009; WANG; KAO; HSIEH, 2003).

O alginato é o termo usado normalmente para se referir ao ânion do ácido algínico, mas também pode se referir aos seus sais ou ao próprio ácido. Ele é um polissacarídeo natural atóxico que, quimicamente, é um copolímero linear formado por blocos de grupos $(1,4) \beta$-D-manuronato (M) e $\alpha$-L-guluronato (G) que em presença de cátions multivalentes, podem formar géis. A composição e extensão das sequências de meros e a massa molar determinam as propriedades físicas do alginato (GEORGE; ABRAHAM, 2006; MCHUGH, 2003; PAUL; SHARMA, 2004; SAETHER et al., 2008).

É obtido a partir de diversos tipos de algas, destacando-se principalmente algumas espécies marinhas de algas marrons. O alginato é usado como espessante na indústria de alimentos em molhos, coberturas, maioneses e iogurtes. Também é usado como estabilizante, reduzindo a formação de cristais de gelo e a taxa de derretimento em sorvetes. Além disso, filmes de alginato de cálcio têm sido usados na preservação de peixes congelados. Na indústria farmacêutica, este composto tem sido usado na liberação controlada de medicamentos e produtos químicos devido a sua sensibilidade ao $\mathrm{pH}$. Microesferas de alginato recobertas com quitosana (melhor propriedade mecânica) tem sido testadas na liberação controlada de vários fármacos (GEORGE; ABRAHAM, 2006; MCHUGH, 2003; SAETHER et al., 2008).

Este biopolímero tem sido amplamente empregado no tratamento de úlceras com grande quantidade de exsudato, pois a troca de íons entre o cálcio do biomaterial e o sódio da úlcera leva à formação de um gel estável a temperatura ambiente que tem capacidade de absorver umidade e manter um micro-ambiente úmido apropriado, principalmente para a 
fase de granulação tecidual (GEORGE; ABRAHAM, 2006; PAUL; SHARMA, 2004; SANKALIA et al., 2007; WANG et al., 2002; WIEGAND; HIPLER, 2010).

A propriedade gelificante é resultado das ligações cooperativas de cátions divalentes, tais como o magnésio, bário, estrôncio e cálcio, com blocos homopoliméricos do polímero. 0 cátion mais utilizado é o cálcio $\left(\mathrm{Ca}^{2+}\right)$, ligando ionicamente nas cavidades eletronegativas, formando um gel termoestável resistente. Outro aspecto positivo do uso do alginato é sua capacidade de servir como bloqueador das terminações nervosas e não se aderir ao leito da lesão, reduzindo possíveis traumas na troca do curativo (DONG; WANG; DU, 2006; PAUL; SHARMA, 2004; RODRIGUES, 2004; WANG et al., 2002).

A quitosana e o alginato são polieletrólitos de cargas opostas, sendo que a quitosana pode apresentar carga líquida positiva e o alginato, carga líquida negativa quando em solução. O complexo polieletrolítico (PEC) de quitosana-alginato possui menor tendência ao intumescimento em relação ao alginato e maior resistência à solubilização em baixos valores de pH, quando comparado à quitosana (HEIN et al., 2008; ; LI et al., 2009; RODRIGUES, 2008; SAETHER et al., 2008).

O comportamento do PEC de quitosana-alginato varia de acordo com o pH. Em pH muito alto, a interação entre o alginato e a quitosana é desfavorecida, assim como em pH muito baixo visto que, nestas condições, ocorre preponderância de ionização do alginato e da quitosana isolados, respectivamente. Para promover a formação de um PEC estável, Cárdenas et al. (2003) propõem o ajuste do pH para 5,28, em um valor intermediário aos valores de pKa da quitosana $(6,3$ a 7,0) (KARAKEÇILI et al., 2007) e do alginato (3,38 para os grupos M e 3,65 para os grupos G) (LI et al., 2009; SAETHER et al., 2008), garantindo que a quitosana esteja potencialmente protonada e o alginato, desprotonado.

A associação destes polímeros origina complexos polieletrolíticos (PECs) ligados por forças eletrostáticas, pontes de hidrogênio, forças de van der Waals e interações hidrofóbicas. Essas associações podem afetar as propriedades dos polímeros interligados, tais como a condutividade elétrica, permeabilidade, solubilidade, características mecânicas, dentre outras (LEE et al., 1999).

O complexo formado entre a quitosana e o alginato é insolúvel em água e é considerado mais efetivo no controle da liberação de materiais incorporados a ele, quando comparado aos polímeros isolados. (YANG; KHOR; LIM, 2000). A associação dos compostos leva a formação de um hidrogel, que em comparação com os polímeros isolados, melhora a 
força estrutural e estabilidade mecânica, além do promissor uso na engenharia tecidual como scaffolds associados a células, fatores de crescimento e na liberação controlada de fármacos (AZEVEDO et al., 2007; GEORGE; ABRAHAM, 2006; LI et al., 2009; LIM et al., 2008).

A etapa de polimerização ocorre devido à natureza catiônica da quitosana em solução, que permite a produção de complexos iônicos com espécies aniônicas, como o alginato, sendo a rede polimérica caracterizada como um micro ambiente hidrofílico com alta quantidade de água e alta densidade de cargas elétricas (ANAL; STEVENS, 2005; GEORGE; ABRAHAM, 2006; PAUL; SHARMA, 2004).

Vários trabalhos que utilizaram o complexo quitosana-alginato mostraram in vivo e principalmente in vitro as propriedades de biodegradação, biocompatibilidade, ausência de imunogenicidade, adesão, crescimento e diferenciação celular com vários tipos celulares (LEUNG et al., 2010; LI et al., 2005; LI; ZHANG, 2005; WANG et al., 2002).

Assim, o PEC de quitosana-alginato pode ser empregado para a confecção de biomembranas com a finalidade de aplicação na terapia de lesões, mostrando-se flexíveis, finas, transparentes e tão eficientes quanto os curativos convencionais (PAUL; SHARMA, 2004). É biocompatível, estável e apresenta degradação relativamente lenta no organismo. Este complexo pode ser processado de diversas formas, existindo uma tendência de confecção de membranas (ou biofilmes) com diferentes quantidades de camadas, para aplicação no tratamento de lesões de pele de difícil cicatrização, as quais apresentam um grande desafio da atualidade (BUENO, 2010; LI et al., 2009).

Pacientes com úlceras crônicas necessitam de um longo tempo de tratamento, resultando em alto custo com cuidados médicos. Um dos principais desafios é a busca por novas substâncias terapêuticas, visando a neoformação tecidual, bem como o entendimento dos processos celulares e fisiológicos envolvidos, por meio da utilização de medicamentos de ação tópica ou sistêmica (FONDER et al., 2008; SEHN et al., 2009).

Diante disso, a pesquisa por compostos naturais não-tóxicos com propriedades estimuladoras da reparação tecidual ganhou importância nos últimos anos, principalmente em recursos para confeç̧ão de produtos cicatrizantes feitos a partir de matéria-prima de baixo custo, que permita um acesso rápido e fácil à população (MANDELBAUM; DI SANTIS; MANDELBAUM, 2003; SEHN et al., 2009).

A quitosana e o alginato, polissacarídeos com grande disponibilidade comercial, renováveis com propriedades intrínsecas de biocompatibilidade, biodegradabilidade e 
cicatrizantes tornam-se materiais ideais para estudos e confecção de curativos adequados às fases da cicatrização (KUCHARSKA et al., 2008; REDDY et al., 2008; RINAUDO, 2008).

Desta forma, buscou-se avaliar a eficácia e os possíveis mecanismos de ação da biomembrana de quitosana-alginato na cicatrização de úlceras cutâneas em ratos Wistar. 


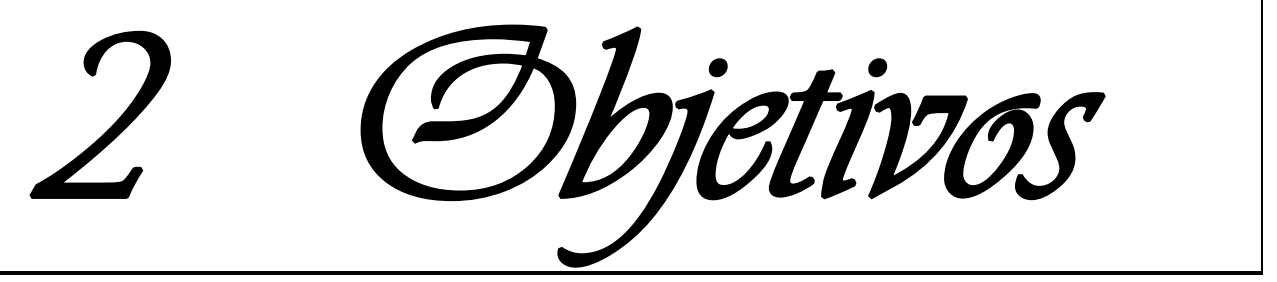




\subsection{Geral}

Avaliar a eficácia da biomembrana de quitosana-alginato na cicatrização de úlceras cutâneas em ratos Wistar.

\subsection{Específicos}

- Avaliar as alterações histológicas quanto ao infiltrado inflamatório, vasos sanguíneos e fibroplasia em cortes histológicos das úlceras tradadas com BQA corados com hematoxilina e eosina (HE);

- Avaliar o infiltrado neutrofílico por meio da dosagem de mieloperoxidase (MPO);

- Avaliar a colagênese em cortes histológicos corados com tricrômio de Gomori (TG);

- Avaliar a colagênese por meio da dosagem de hidroxiprolina (OHP) - padronização do método;

- Avaliar a reepitelização por meio do cálculo do índice de cicatrização das úlceras (ICU) em ratos tratados com a biomembrana de quitosana-alginato. 


\section{Chaterial e Chétodos}


Os protocolos envolvendo o uso de animais em experimentação foram realizados de acordo com os Princípios Éticos na Experimentação Animal adotado pelo Colégio Brasileiro de Experimentação Animal (COBEA). O projeto foi aprovado pela Comissão de Ética em Experimentação Animal (CETEA), da Faculdade de Medicina de Ribeirão Preto, Universidade de São Paulo (FMRP-USP), sob o número de processo 085/2011 (Anexo A).

Todo o estudo teve colaboração e orientação do Prof. Dr. Marco Andrey Cipriani Frade do Departamento de Clínica Médica, Divisão de Dermatologia da Faculdade de Medicina de Ribeirão Preto, Universidade de São Paulo e do seu pós-doutorando Thiago Antônio Moretti de Andrade.

\subsection{Animais}

Todos os animais envolvidos no projeto foram recebidos cinco dias antes do início dos experimentos para aclimatação, mantidos em gaiolas coletivas até o dia do experimento.

Foram utilizados 65 ratos Wistar machos, com peso entre 180 e 220 g, obtidos do Biotério Central da Faculdade de Medicina de Ribeirão Preto. Os animais foram mantidos em condições de isolamento durante todo experimento em gaiolas individualizadas, com água e ração ad libitum e ciclos alternados de luminosidade a cada 12 horas no Biotério do Departamento de Clínica Médica no Anexo A da FMRP-USP.

\subsection{Confecção da biomembrana de quitosana-alginato}

Este processo teve a colaboração da Profa. Dra. Ângela Maria Moraes da Faculdade de Engenharia Química, Laboratório de Desenvolvimento de Processos Biotecnológicos da Universidade Estadual de Campinas (UNICAMP), onde foram produzidos os biomateriais (BUENO, 2010), gentilmente cedidos para os testes in vivo.

Toda a preparação das biomembranas de quitosana-alginato foi baseada na metodologia proposta por Yang, Khor e Lim (2000) e adaptada por Wang et al. (2002), fundamentada na formação de coacervados. Todo o procedimento foi descrito detalhadamente por Rodrigues (2008), contendo algumas modificações feitas por Bueno 
(2010) para que houvesse um aumento na escala do processo, além de facilitar a produção. Esta preparação do biomaterial foi feita pela doutoranda MSc Cecilia Zorzi Bueno.

Um volume de $180 \mathrm{~mL}$ de uma solução alginato 0,5\% em água Milli-Q foi colocado em um reator de aço inoxidável encamisado com diâmetro interno de $10 \mathrm{~cm}$ e altura de $20 \mathrm{~cm}$. Esse sistema é conectado a um banho termostático para manter todo o processo constante a $25{ }^{\circ} \mathrm{C}$. Foram misturados $90 \mathrm{~mL}$ de acetona PA a $90 \mathrm{~mL}$ de solução de quitosana $1 \%$ em ácido acético $2 \%(1: 1)$ em vidro com tampa e agitados até que a mistura tenha ficado totalmente homogênea. Essa mistura foi colocada em uma seringa de vidro BD 50, acoplada a uma bomba de infusão ST $670 \mathrm{~T}$, para ser adicionada lentamente, em forma de gotejamento, à solução de alginato 0,5\% dentro do reator, a uma vazão de $160 \mathrm{~mL} / \mathrm{h}$, enquanto o reator é mantido a uma agitação de 500 rpm.

Após o término do gotejamento da solução polimérica de quitosana, a agitação foi aumentada para $1000 \mathrm{rpm}$ durante 10 minutos. Foi adicionado $16,8 \mathrm{~mL}$ de $\mathrm{NaOH} 1 \mathrm{M}$, com auxílio de uma pipeta graduada por toda a região do reator e por mais 10 minutos foi mantido o sistema a $1.000 \mathrm{rpm}$ para que o pH seja ajustado a 5,28. Essa fase é de extrema importância, já que neste $\mathrm{pH}$ a quitosana apresenta-se protonada e o alginato, desprotonado. Para concluir a etapa de reação dos reagentes junto à solução polimérica, 3,6 $\mathrm{ml}$ de $\mathrm{CaCl}_{2}$ a $2 \%$ foi adicionado lentamente nas bordas do reator, com auxílio de micropipeta, mantendo a agitação por mais 10 minutos para que ocorra a complexação das carboxilas remanescentes com os íons $\mathrm{Ca}^{2+}$.

Ao término dos últimos 10 minutos, a associação polimérica formada foi colocada em um Kitassato e desaerada com auxílio de uma bomba de vácuo por cerca de 90 minutos. Em seguida, a mistura foi dividida igualmente em 2 placas de poliestireno circular de $15 \mathrm{~cm}$ de diâmetro e levada a estufa por 20 horas a $37^{\circ} \mathrm{C}$ em um prato giratório.

Após isso, as membranas foram colocadas em $150 \mathrm{~mL}$ de $\mathrm{CaCl}_{2}$ gelado, a $2 \%$, por 1 hora, para uma reticulação das cadeias de alginato que ainda estiverem livres. Para lavar as membranas do banho com $\mathrm{CaCl}_{2}$, foram feitas 2 imersões consecutivas em $200 \mathrm{~mL}$ de água deionizada por 1 hora cada imersão e cada biomembrana formada. Para a secagem final, as membranas foram deixadas em temperatura ambiente durante 24 horas, prensando as bordas das membranas para evitar o encolhimento. Depois de secas, as bordas do biomaterial foram cortadas para que fossem obtidas biomembranas circulares, lisas e esticadas (Figura 1). 
Figura 1 - Produção das biomembranas de quitosana-alginato
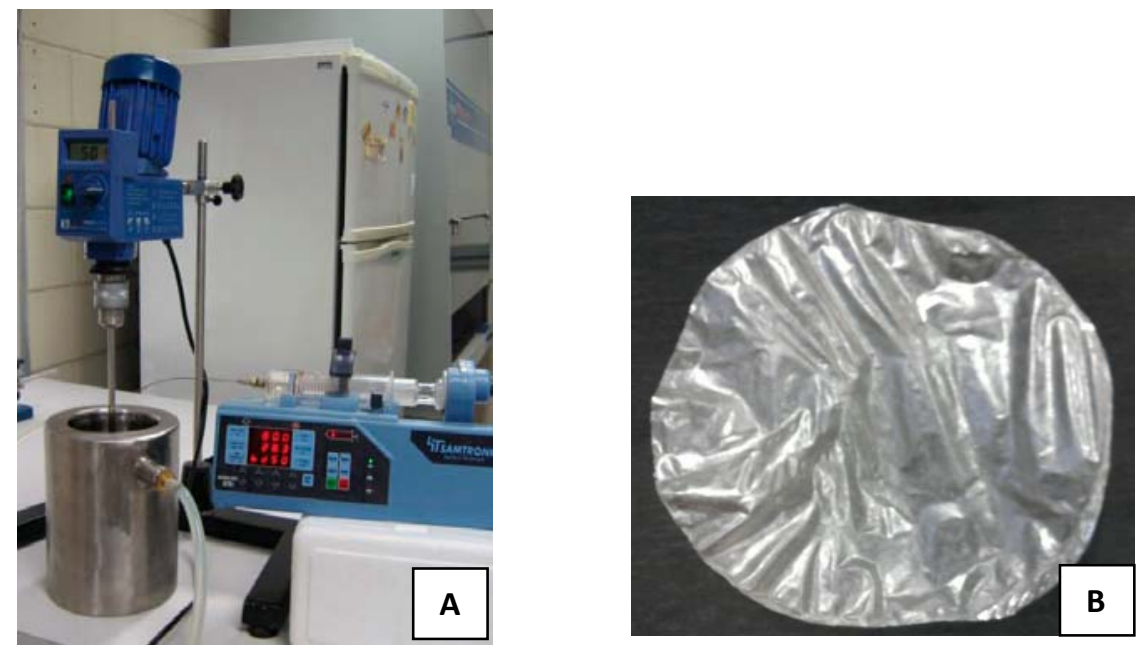

(A) Sistema utilizado na preparação da mistura polimérica formadora das biomembranas.

(B) Biomembrana de quitosana-alginato utilizada como tratamento das úlceras cutâneas. Fonte: Bueno (2010)

\subsection{Padronização dos grupos}

A distinção dos grupos foi conforme o tratamento utilizado em ambas as úlceras de cada animal:

BQA: 25 animais cujas úlceras foram tratadas com a biomembrana de quitosanaalginato (BQA) previamente hidratadas em soro fisiológico 0,9\% e acompanhadas por 2, 7, 10, 14 e 21 dias ( $n=5$ animais por tempo de tratamento);

SF: 25 animais cujas úlceras foram tratadas somente com soro fisiológico 0,9\% (SF) e acompanhadas por $2,7,10,14$ e 21 dias ( $n=5$ animais por tempo de tratamento);

GZ: 15 animais cujas úlceras foram somente recobertas com gaze e esparadrapo e acompanhadas por 7, 10 e 14 dias ( $n=5$ animais por tempo de tratamento). 


\subsection{Procedimento cirúrgico: úlceras cutâneas dorsais}

Os ratos foram pesados, anestesiados por via intraperitoneal com hidrato de cloral $4 \%$ na dose de $1.0 \mathrm{~mL} / 100 \mathrm{~g}$ de peso do animal. Posteriormente, os animais foram tricotomizados, posicionados na mesa operatória em decúbito ventral e após assepsia do dorso com álcool 70\%, duas excisões cirúrgicas circulares foram feitas com punch $1,5 \mathrm{~cm}$ de diâmetro com o animal em decúbito lateral, atingindo a região dermo-epidérmica (Figura 2). A pele excisada para confecção das úlceras nos animais foi acondicionada em cassete histológica e eppendorf para posteriores estudos histológicos e bioquímicos respectivamente, representando amostras do dia inicial (dia 0 , controle sem tratamento).

Figura 2 - Confecção de duas úlceras cutâneas no dorso de cada animal

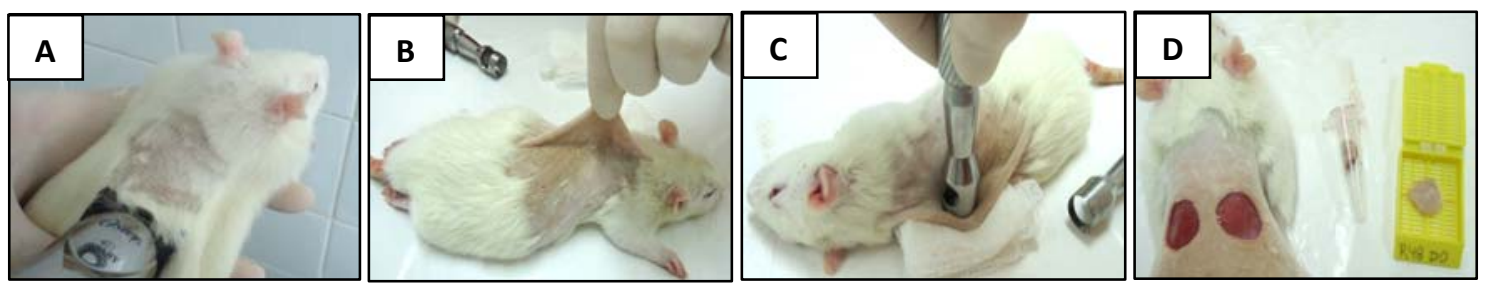

(A) Tricotomia do dorso dos. (B) Animal em decúbito ventral após assepsia para determinação do local para confecção das úlceras. (C) Animal em decúbito lateral para confecção de duas úlceras na região dorsal do rato com punch de $1,5 \mathrm{~cm}$ de diâmetro. (D) Úlceras confeccionadas e amostras do tecido cutâneo excisados a ser acondicionados.

Fonte: Caetano (2012)

As biomembranas de quitosana-alginato, previamente hidratadas em soro fisiológico, foram colocadas em ambas as úlceras de cada animal do grupo BQA e somente retiradas após a eutanásia. Após a aplicação dos respectivos tratamentos, as úlceras de todos os animais receberam curativo oclusivo com gaze e esparadrapo. Os animais de ambos os grupos tiveram o curativo oclusivo trocados diariamente, seguidos de hidratação da úlcera (grupo SF) e da biomembrana (BQA) até o $7^{\circ}$ dia de seguimento (Figura 3). As úlceras dos animais do grupo GZ não foram hidratadas e os curativos foram retirados somente no dia da aquisição das imagens (dias 7, 10 e 14).

Após a cirurgia, foi aplicado por via intraperitoneal dose única de DIPIRONA $50 \mathrm{mg} / \mathrm{Kg}$ de peso diluída em salina. Após receberem o tratamento, os animais foram colocados em gaiolas individualizadas, onde permaneceram até o dia do sacrifício. 
Figura 3 - Curativo oclusivo feito em cada animal após receberem os respectivos tratamentos
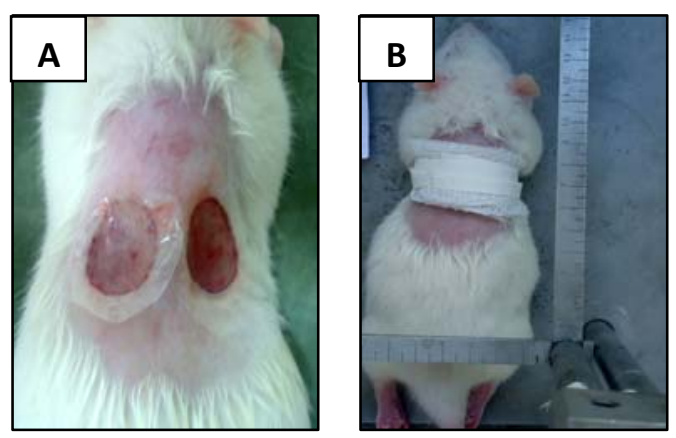

(A) Ambas as úlceras dos animais do grupo BQA receberam a biomembrana de quitosana-alginato previamente hidratadas com soro fisiológico 0,9\%. (B) Curativo oclusivo com gaze e esparadrapo feito em todos os animais.

Fonte: Caetano (2012)

\subsection{Coleta do material para estudo}

Foram eutanasiados 5 animais por grupo e tempo de seguimento ( $\mathrm{n}=10$ úlceras), nos dias $2,7,10,14$ e 21 com dose excessiva de anestésico (hidrato de cloral 4\%). Ambas as úlceras de cada animal foram fotografadas separadamente pela câmera digital Sony DSCW320, modo básico (sem flash, sem zoom, resolução de 2 Mega Pixels).

Na aquisição das imagens, foi utilizado um aparato de metal onde a câmera foi fixada numa base de alumínio distando $30 \mathrm{~cm}$ de uma régua perpendicular à úlcera. Esta régua foi utilizada para a padronização da unidade de área das lesões, em centímetros (Figura 4).

Figura 4 - Suporte utilizado para aquisição das imagens
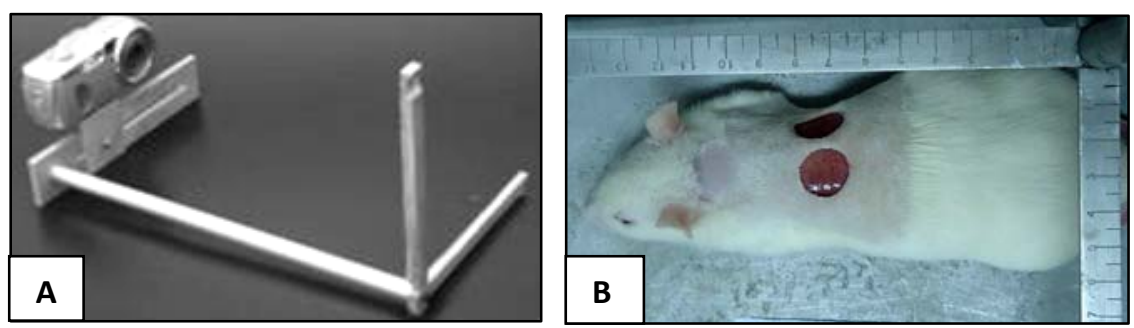

(A) Suporte utilizado para padronização da fotografia das úlceras e também para aferição das mesmas utilizando o cálculo da área das lesões $\left(e m \mathrm{~mm}^{2}\right.$ ). (B) Fotografia padronizada da úlcera esquerda de um animal utilizando o suporte.

Fonte: Caetano (2012) 
Em seguida, foram coletadas amostras das úlceras/cicatrizes para estudos histológicos ( $n=5$ amostras por tempo e por tratamento) dos animais do grupo BQA e SF nos dias 2, 7, 14 e 21. A pele dorsal ao redor das úlceras foi recortada e com o auxílio do punch histológico de $1,5 \mathrm{~cm}$ de diâmetro foi feita uma biopsia cilíndrica da região de cada úlcera/cicatriz de cada animal (Figura 5).

Como demonstrado na figura 2D, uma das amostras de cada animal foi acondicionada em cassetes histológicas, fixada em solução de formaldeído 3,7\% (v/v) e foi seguido processamento habitual para estudo histológico. A outra amostra foi colocada em eppendorf e imediatamente congelada a -80 ㄷ C para posterior realização de ensaios bioquímicos para dosagem de hidroxiprolina (OHP) e mieloperoxidase (MPO).

Figura 5 - Biópsia da úlcera/cicatriz de cada animal para análise
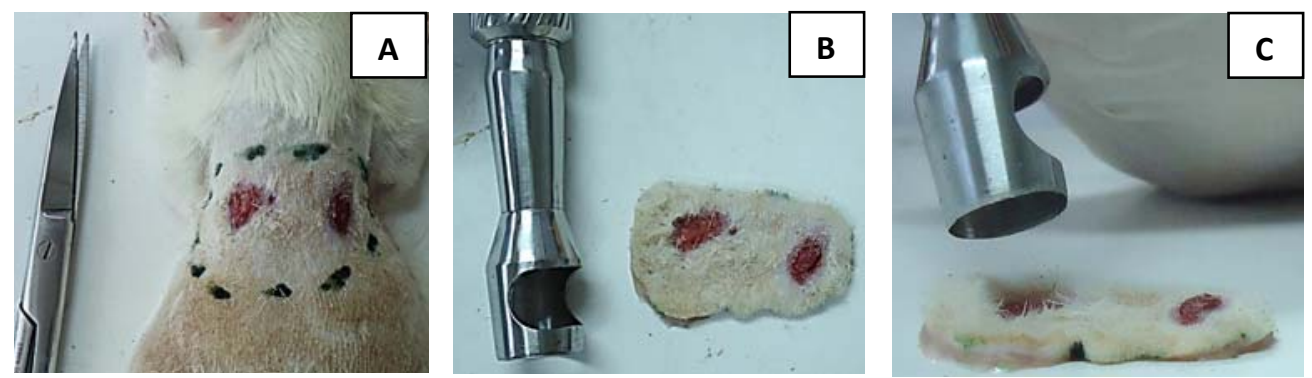

(A) Região dorsal contendo ambas as úlceras cutâneas. (B) Fragmento dorsal recortado contendo ambas as úlceras. (C) Excisão circular da úlcera/cicatriz a ser feito com punch histológico de $1,5 \mathrm{~cm}$ de diâmetro nos dias 2, 7, 14 e 21 nos grupos BQA e SF para estudos histológicos e bioquímicos. Fonte: Caetano (2012)

\subsection{Avaliação do índice de cicatrização das úlceras pelo ImageJ}

A partir das fotografias, as áreas das úlceras foram calculadas pelo software ImageJ 1.46 e em seguida foi calculado o índice de cicatrização das úlceras (ICU) para análise da reepitelização, cujo valor é equivalente ao quociente entre a diferença das Áreas Inicial e Final e a Área Inicial [ICU=(Ai-Af)/Ai]. Valores de ICU maiores que zero representam diminuição da área ulcerada, valores menores que zero representam aumento da área e valores iguais a 1,0 representam reepitelização completa (CAETANO et al., 2009; MINATEL et 
al., 2009; ROBSON et al., 2000). A área inicial corresponde ao dia do procedimento cirúrgico (dia 0) e a área final corresponde ao dia da eutanásia (dias 2, 7, 10, 14 ou 21).

Formula (1)

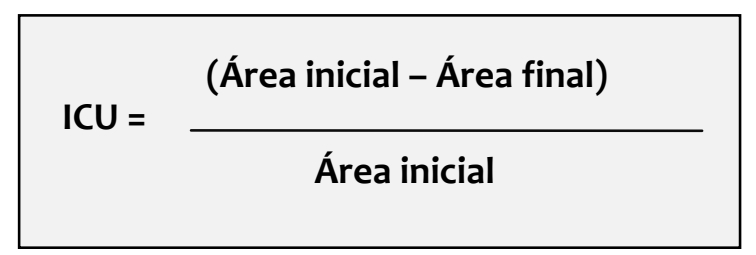

\subsection{Estudo histológico (histomorfometria)}

As biopsias acondicionadas em cassetes histológicas foram fixadas em solução tamponada de formaldeído 3,7\% (v/v) $(\mathrm{pH} 7,4)$ durante 24 horas e posteriormente processados em padrão habitual para o estudo histológico. Após o processamento, os fragmentos foram incluídos em parafina a $60^{\circ} \mathrm{C}$ e os blocos foram seccionados em cortes histológicos de 3,0 $\mu \mathrm{m}$ e então corados com hematoxilina e eosina simultaneamente e com o mesmo tempo para avaliação do infiltrado inflamatório, número de fibroblastos e vasos sanguíneos nas amostras coletadas de cada animal nos diferentes tempos e tratamentos. As lâminas histológicas para análise da colagênese foram feitas do mesmo modo, porém coradas com tricrômio de Gomori.

\subsubsection{Avaliação quantitativa por imagem quanto ao infiltrado inflamatório, angiogênese e} fibroplasia

As secções histológicas coradas com hematoxilina e eosina de cada animal do grupo BQA e SF nos diferentes dias de seguimento ( $n=5$ fragmentos por grupo e tempo) foram visualizadas no microscópio óptico LEICA ${ }^{\circledR}$ DM 4000B com câmera LEICA ${ }^{\circledR}$ DFC 280 utilizando o software LAS ${ }^{\circledR}$ - Leica Application Suite - para captura das imagens. 
Para a quantificação do infiltrado inflamatório e fibroplasia foram adquiridos 8 campos por lâmina sob aumento de 400x, sendo 4 campos de epiderme e derme superior e 4 campos de derme inferior e hipoderme. Antes do processo de captura das imagens propriamente dito, todas as imagens foram digitalizadas padronizando-se a objetiva, a intensidade da luz do microscópio e a altura do condensador (ANDRADE et al., 2011; GONÇALVES et al., 2003).

Para a análise quantitativa da angiogênese foram capturadas imagens em série no sentido epiderme-derme-hipoderme, em aumento de 100x para todos os cortes histológicos. Em seguida, essas imagens foram montadas em série pelo Adobe Photoshop CS5, de modo que a quantificação de vasos sanguíneos fosse realizada por meio de uma imagem que correspondia a toda extensão do tecido cutâneo (epiderme-derme-hipoderme).

Foi utilizado o Plugin "Cell Counter" do software ImageJ 1.46 para contagem de células do infiltrado inflamatório, fibroblastos e vasos sanguíneos. A diferenciação de cada célula foi feita pelo observador na imagem da lâmina. O software realiza a contagem a cada clique do observador sobre cada célula, sendo apresentada a contagem total ao final de cada análise.

Esse protocolo foi aplicado em 5 amostras diferentes $(n=5)$ de cada tempo e tratamento, sendo o resultado final a média do número de infiltrado inflamatório, fibroblastos e vasos sanguíneos quantificados. A média final encontrada representa a quantidade destas células encontradas em cada uma das 5 amostras estudadas.

\subsubsection{Avaliação quantitativa por imagem quanto à colagênese}

Para a quantificação histológica da colagênese, foram capturados 6 campos em aumento de $100 x$ de cada lâmina corada com tricrômio de Gomori, sendo 3 campos de epiderme e derme superior e 3 campos de derme inferior e hipoderme .

Foi utilizado o Plugin "Colour Deconvolution" do software ImageJ 1.46 para quantificação da porcentagem da cor azul (colágeno) na área total da imagem. Este Plugin reconhece as cores da imagem e as decompõe em três cores: azul (colágeno), vermelho e roxo. Em seguida, por meio da opção Threshold, toda área da imagem a ser quantificada (tom azul) foi marcada em vermelho e padronizou-se as barras de tons de azul em 0 (tom 
máximo) e 115 (tom mínimo) para quantificar a porcentagem de azul desejada e igual para todas as imagens na área total da imagem.

Esse protocolo foi também aplicado em 5 amostras diferentes $(n=5)$ de cada tratamento e de cada tempo, sendo o resultado final a média da percentagem de área de colágeno. A média final encontrada representou a quantidade de colágeno em cada uma nas 5 amostras estudadas.

\subsection{Dosagem da enzima mieloperoxidase (MPO)}

A densidade do infiltrado neutrofílico na lesão dos animais foi aferida pela dosagem da mieloperoxidase, enzima predominante em grande quantidade nos neutrófilos (SOUZA et al., 2001). Para tanto, as biópsias ( $n=5$ por tempo e por tratamento) dos animais do grupo BQA e SF foram acondicionadas em eppendorf's de $2 \mathrm{~mL}$ e permaneceram em freezer $-80^{\circ} \mathrm{C}$ até o dia da dosagem, como previamente descrito. Retirados do freezer e mantidos em gelo, os fragmentos foram pesados em balança analítica. Colocou-se $300 \mu \mathrm{L}$ de tampão 1 ( $\mathrm{NaPO}_{4}$ $0,02 \mathrm{M}+\mathrm{NaCl} 0,1 \mathrm{M}+\mathrm{Na}_{2}$ EDTA $\left.0,015 \mathrm{M}, \mathrm{pH} 4,7\right)$ nas amostras para serem totalmente trituradas e homogeneizadas em POLYTRON ${ }^{\circledR}$ PT 3100 a 13000 rpm. Após este procedimento, as amostras foram centrifugadas por 15 minutos a $3.000 \mathrm{rpm}$ e o sobrenadante descartado. O pellet de cada amostra foi ressuspendido em $1 \mathrm{~mL}$ de solução de lise $\mathrm{NaCl} 2 \%$, homogeneizado no vortex por 30 segundos seguido de nova centrifugação por 15 minutos a $3.000 \mathrm{rpm}$. Descartado o sobrenadante, o pellet foi ressuspendido em tampão $2\left(\mathrm{NaPO}_{4}\right.$ contendo 0,5\% de brometo de hexadeciltrimetilamônio) e centrifugado por 20 minutos a $15.000 \mathrm{rpm}$, obtendo um sobrenadante final. Em seguida, um volume final de $50 \mu \mathrm{L}$ (45 $\mu \mathrm{L}$ de $\mathrm{NaPO}_{4}+5 \mu \mathrm{L}$ do sobrenadante das amostras após a última centrifugação) foram colocadas em uma microplaca de 96 poços para o ensaio. Foi feita uma curva padrão de neutrófilos obtidos da cavidade peritoneal 6 horas após camundongos serem injetados com carragenina. Em cada poço da placa foram adicionados $25 \mu \mathrm{L}$ de TMB (“3, 3', 5, 5' tetramethylbenzidine") e em seguida $100 \mu \mathrm{L}$ de $\mathrm{H}_{2} \mathrm{O}_{2}$. A microplaca foi mantida em estufa a $37^{\circ} \mathrm{C}$ por 5 minutos. A seguir, a reação foi interrompida com ácido sulfúrico $4 \mathrm{M}$ e lida em leitor de placas a $450 \mathrm{~nm}$. Os resultados foram expressos em número de neutrófilos $\mathrm{x}$ $10^{3} / \mathrm{mg}$ de tecido. 


\subsection{Dosagem de hidroxiprolina (OHP)}

A análise quantitativa da colagênese por método bioquímico foi realizada por meio da dosagem de hidroxiprolina nas biópsias coletadas dos ratos, mantidas em freezer -80 으, como previamente descrito, seguindo a metodologia proposta por Reddy e Enwemeka (1996) e Reddy et al. (2008) com algumas modificações.

Para a realização das dosagens de hidroxiprolina, as biópsias foram descongeladas e incubadas em estufa com circulação de ar à temperatura de $60^{\circ} \mathrm{C}$ em microtubos abertos, overnight (15 horas por amostra). Após a incubação, as amostras foram pesadas em balança analítica até a obtenção de peso constante e então foram transferidas para tubos de ensaio de vidro com tampa.

Volumes de ácido clorídrico $(\mathrm{HCl}) 6 \mathrm{~N}$ foram adicionados, utilizando-se a proporção de $100 \mu \mathrm{L}$ de $\mathrm{HCl}$ por $1,0 \mathrm{mg}$ de tecido seco. As amostras foram homogeneizadas, por 10 segundos, com o homogeneizador de tecidos Polytron e então submetidas à hidrólise ácida, que consistiu na incubação das amostras em $\mathrm{HCl}$ a 130 ㄷ C durante 4 horas.

Após o período de hidrólise e com as amostras à temperatura ambiente, foram transferidos $500 \mu \mathrm{L}$ de cada amostra para um tubo de ensaio de vidro para ajustar o $\mathrm{pH}$ para 7,0 com hidróxido de sódio $(\mathrm{NaOH}) 2 \mathrm{M}$. A partir deste hidrolisado, com pH neutro, foram pipetados $10 \mu \mathrm{L}$ de cada amostra para uma microplaca de 96 poços. Foram preparadas soluções-padrão de hidroxiprolina nas concentrações de 1,0; 2,0;4,0; 6,0; 8,0; 10; 20;40; 60; 80 e $100 \mu \mathrm{g} / \mathrm{mL}$, usando-se o tampão citrato-acetato pH 6,5 como veículo. Após pipetar a curva e as amostras na microplaca, foram adicionados $90 \mu \mathrm{L}$ de solução de cloramina T 0,056M a cada poço e a microplaca foi incubada à temperatura ambiente durante 25 minutos. Ao final da incubação, as amostras oxidadas em cada poço foram então submetidas à adição de $100 \mu \mathrm{L}$ do reagente de Ehrlich para a formação do cromóforo. A microplaca foi novamente incubada a $60 \circ \mathrm{C}$ durante 20 minutos.

Após a incubação, a microplaca foi homogeneizadas em um homogeneizador para microplacas a $20 \mathrm{rpm}$ durante 10 minutos. A leitura da absorbância foi realizada a $550 \mathrm{~nm}$, a uma temperatura ambiente. As leituras foram realizadas em períodos não superiores a 30 minutos após o final da incubação. O teste foi realizado em duplicata tanto para as amostras quanto para as soluções-padrão de hidroxiprolina. 
Os valores das absorbâncias foram plotados, determinando-se a equação da reta e comparando as absorbâncias das concentrações conhecidas da curva padrão de hidroxiprolina com as absorbâncias das amostras, determinando-se as concentrações de hidroxiprolina nas amostras, primeiramente por volume de $\mathrm{HCl}$ usado e finalmente por miligrama de tecido seco.

\subsection{Análise dos resultados}

Para análise de todas as variáveis foi utilizado o teste $t$ Student (comparação 2 a 2) para comparação entre os grupos BQA, SF e GZ em todos os dias de seguimento.

Foi utilizado o software GraphPad Prism 5.0 para realização dos gráficos e dos testes estatísticos. Os valores de $p<0,05$ mostram evidências estatísticas de que há diferença entre os dados em questão, com intervalo de confiança de $95 \%$. 


$$
4 \text { Resultados }
$$




\subsection{Processo inflamatório}

\subsubsection{Avaliação do infiltrado inflamatório total}

Com a finalidade de avaliar qualitativamente o processo inflamatório nas úlceras de ambos os grupos experimentais, empregou-se a coloração com hematoxilina e eosina. A análise histológica qualitativa das úlceras/cicatrizes evidenciou no grupo BQA, no 2음 dia de seguimento, um denso infiltrado inflamatório composto predominantemente de neutrófilos em todo corte histológico, até mesmo em camadas mais inferiores. No $7^{\circ}$ dia, ambos os grupos apresentaram quantidades semelhantes de células inflamatórias (principalmente macrófagos) associadas ao grande influxo de fibroblastos. A partir do $14^{\circ}$ dia, ambos os grupos apresentaram redução do infiltrado inflamatório (Figura 6).

A análise quantitativa do infiltrado inflamatório nas secções histológicas, empregando-se a histomorfometria mostrou, no $2^{\circ}$ dia de seguimento, diferença estatística quanto ao número de células inflamatórias entre os grupos, com maior celularidade no grupo BQA em relação ao SF ( $p=0,0134)$. No $7^{\circ}$ dia, o grupo BQA apresentou uma importante redução de células inflamatórias em relação ao $2^{\circ}$ dia $(p=0,0038)$, enquanto que no grupo SF não foi observada redução, mantendo-se com a mesma celularidade. No 14을 dia houve semelhança entre os grupos e redução do infiltrado inflamatório em relação ao 70 dia $(p<0,05)$ e assim permaneceram até o último dia de seguimento (Figura 7). 
Figura 6 - Fotomicrografia da área ulcerada de ambos os grupos ao longo do seguimento

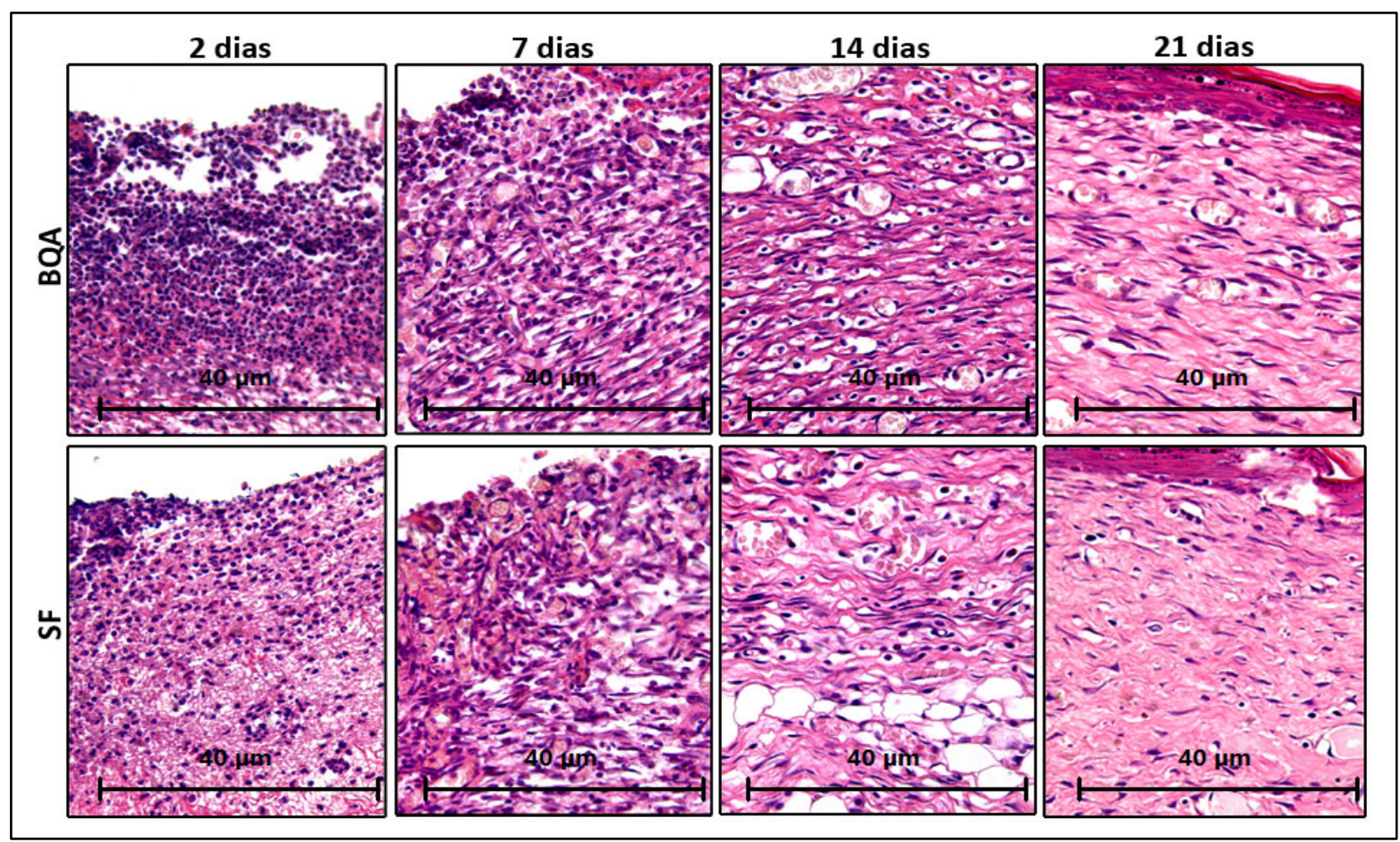

Destaca-se o infiltrado inflamatório, vasos sanguíneos e fibroblastos nos grupos tratados com a biomembrana de quitosana-alginato hidratadas com soro fisiológico (BQA) e somente com soro fisiológico (SF), por 2, 7, 14 e 21 dias. Coloração com hematoxilina e eosina.

Fonte: Caetano (2012)

Figura 7 - Infiltrado inflamatório total nas úlceras cutâneas de ambos os grupos ao longo do seguimento

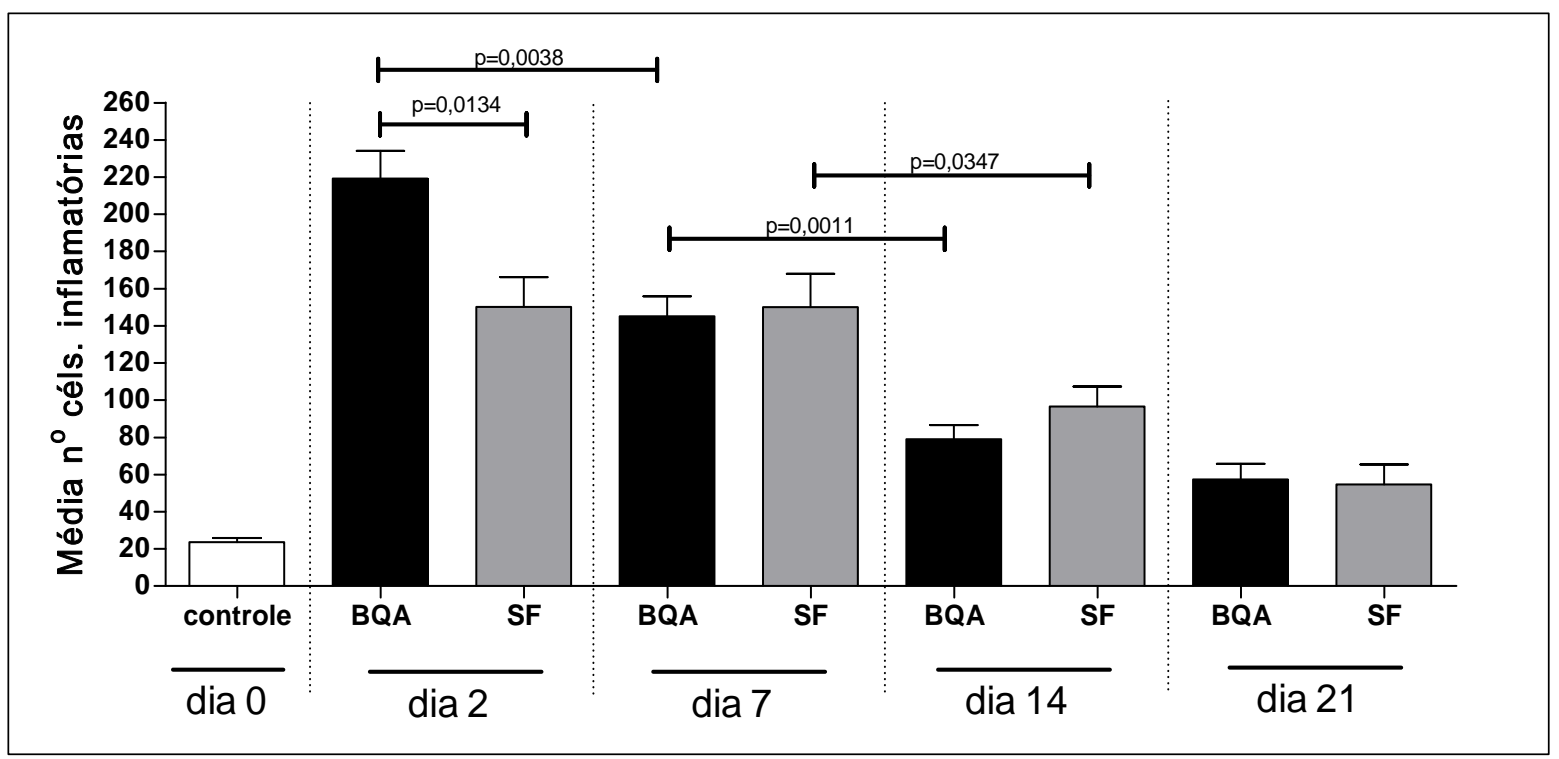

Quantificação das células inflamatórias totais (por histomorfometria) nas úlceras cutâneas tratadas com biomembrana de quitosana-alginato hidratadas com soro fisiológico (BQA) e somente soro fisiológico (SF), por 2, 7, 14 e 21 dias.

Fonte: Caetano (2012) 


\subsubsection{Dosagem de mieloperoxidase (MPO)}

Com a finalidade de avaliar bioquimicamente a participação neutrofílica no processo inflamatório, empregou-se o método de dosagem da enzima mieloperoxidase (MPO) nos diferentes dias de tratamento entre os grupos. Como se verifica, na figura 8 , no 20 dia ambos os grupos apresentaram altas quantidades da enzima mieloperoxidase $(p>0,05)$. No 7ㅇ dia, o grupo BQA apresentou uma redução importante do infiltrado neutrofílico em relação ao seu $2 \circ$ dia $(p=0,0326)$ e uma dosagem estatisticamente inferior ao grupo $S F(p=0,0043)$. No 14ㅇ e 21일 ambos os grupos apresentaram-se semelhantes e com quantidades reduzidas de MPO em relação aos dias anteriores.

Figura 8 - Dosagem da mieloperoxidase nas úlceras cutâneas de ambos os grupos ao longo do seguimento

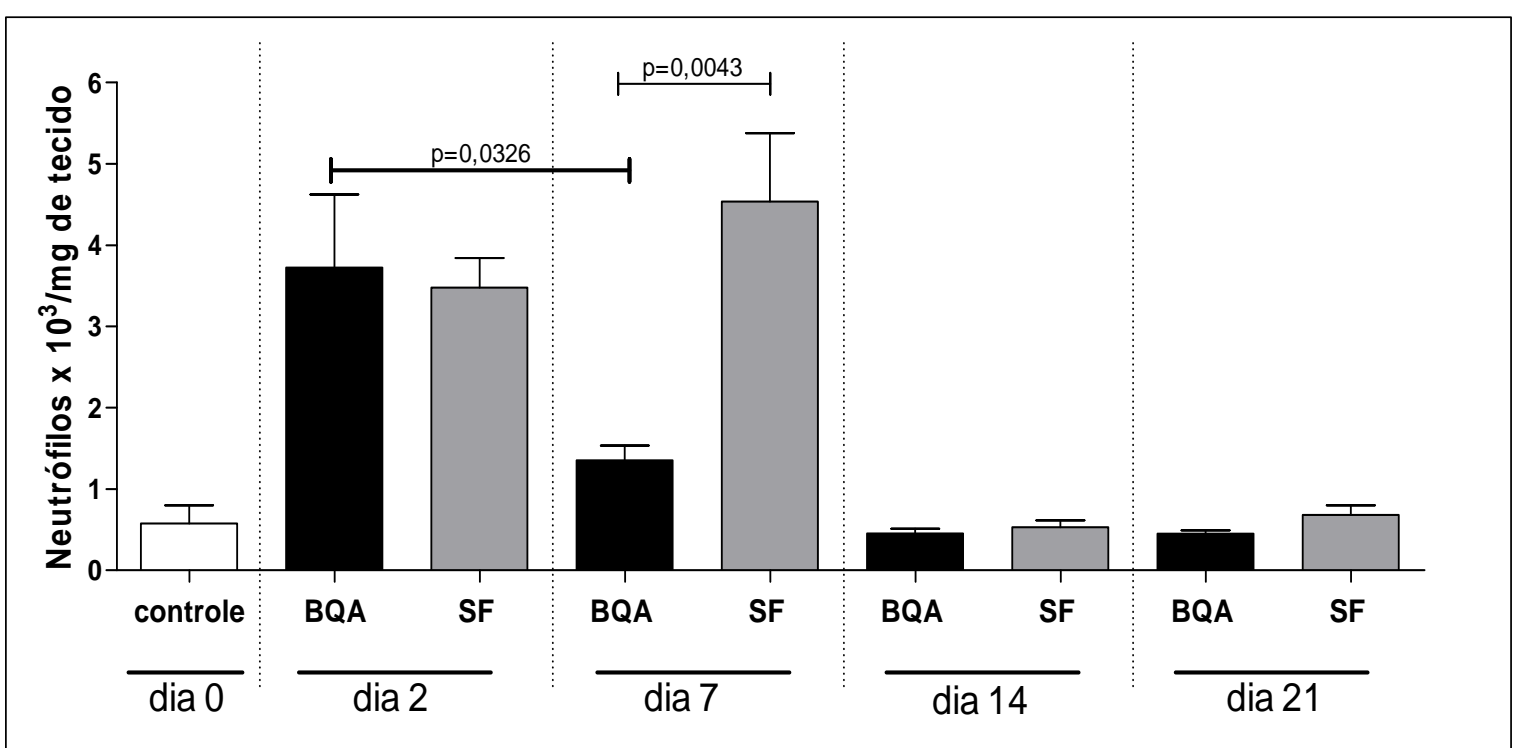

Quantificação da enzima mieloperoxidase (por dosagem bioquímica) nas úlceras cutâneas tratadas com biomembrana de quitosana-alginato hidratadas com soro fisiológico (BQA) e somente com soro fisiológico (SF), por 2, 7, 14 e 21 dias.

Fonte: Caetano (2012) 


\subsection{Avaliação da angiogênese}

Pela análise histológica qualitativa das úlceras/cicatrizes, pode-se observar quantidade pronunciada de vasos sanguíneos a partir do $7^{\circ}$ dia em ambos os grupos principalmente no tecido em formação próximo ao leito da úlcera, caracterizando o tecido de granulação (Figura 6).

$\mathrm{Na}$ análise histológica quantitativa da angiogênese, foram feitas contagens de vasos sanguíneos em seç̧ões histológicas coradas com hematoxilina e eosina. Não houve diferença estatística entre os grupos BQA e SF em todo período de seguimento. No entanto, observou-se aumento importante da quantidade de vasos no $7^{\circ}$ dia em ambos os grupos $(p<0,05)$, conforme apresentado na figura 9.

Figura 9 - Angiogênese nas úlceras cutâneas de ambos os grupos ao longo do seguimento

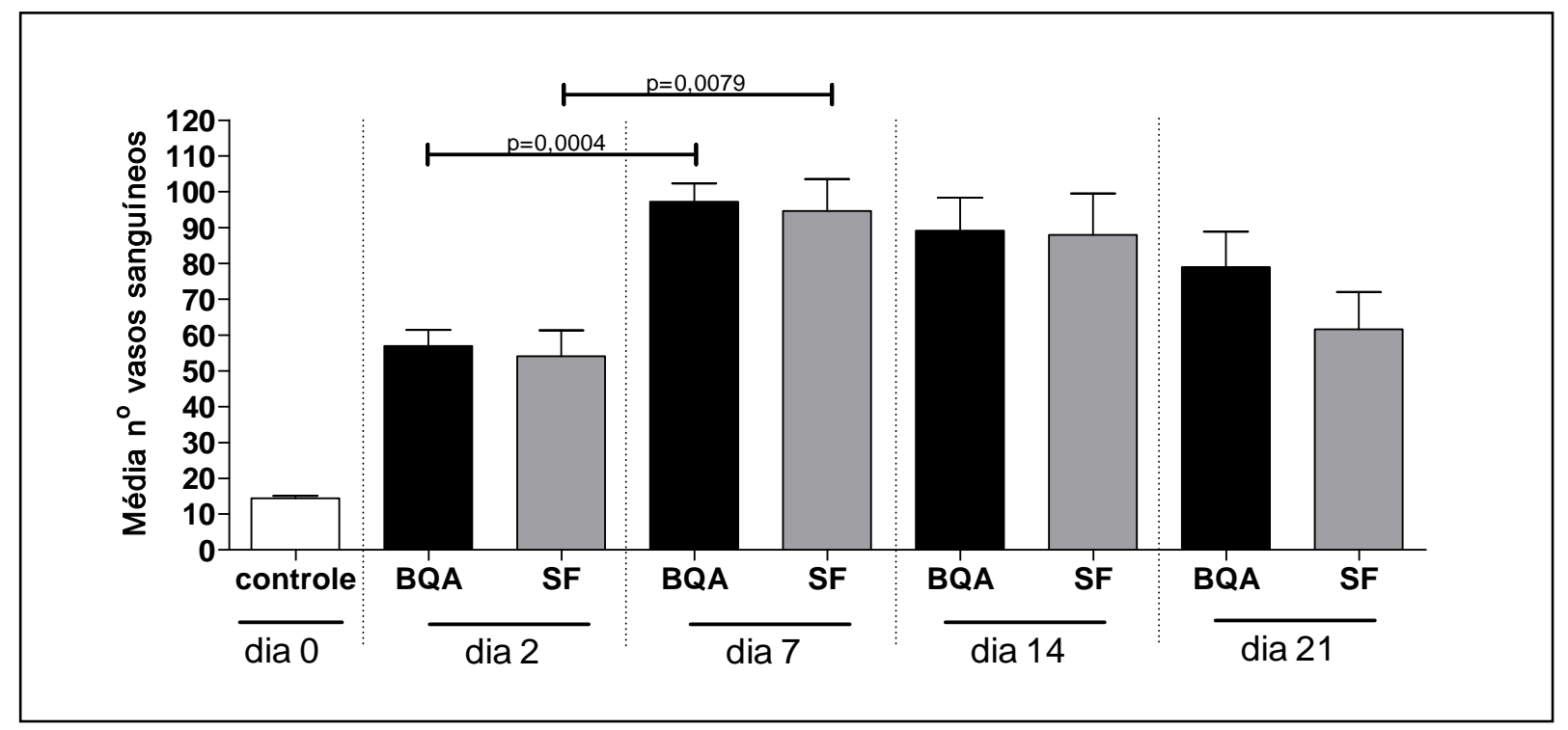

Quantificação dos vasos sanguíneos (por histomorfometria) nas úlceras cutâneas tratadas com biomembrana de quitosana-alginato hidratadas com soro fisiológico (BQA) e somente soro fisiológico (SF), por 2, 7, 14 e 21 dias.

Fonte: Caetano (2012) 


\subsection{Avaliação da fibroplasia}

Pela análise histológica qualitativa (coloração HE) das úlceras/cicatrizes, observou-se importante estímulo à fibroplasia no $7^{\circ}, 14^{\circ}$ e $21^{\circ}$ dias em ambos os grupos com alto grau de diferenciação. No $21^{\circ}$ dia, os fibroblastos, principalmente no grupo BQA, apresentaram-se mais organizados no novo tecido formado, dispostos paralelamente à úlcera, diferente do grupo SF (Figura 6).

Em relação à análise quantitativa da fibroplasia, no $2^{\circ}$ dia de seguimento ambos os grupos apresentaram quantidades reduzidas e semelhantes de fibroblasto. A partir do $7^{\circ}$ dia, ambos os grupos apresentaram importante proliferação de fibroblastos em relação ao $2^{\circ}$ dia, de modo que o grupo BQA apresentou maiores quantidades em relação ao grupo SF no 7ㅇ $(p=0,0275)$ e $14^{\circ}$ dia $(p=0,0086)$. No $21^{\circ}$ dia, o grupo BQA apresentou redução significativa de fibroblastos em relação ao 14 $(p=0,0319)$, enquanto o grupo SF permaneceu com quantidades semelhantes em todo período a partir do 70 dia (Figura 10).

Figura 10 - Fibroplasia nas úlceras cutâneas de ambos os grupos ao longo do seguimento

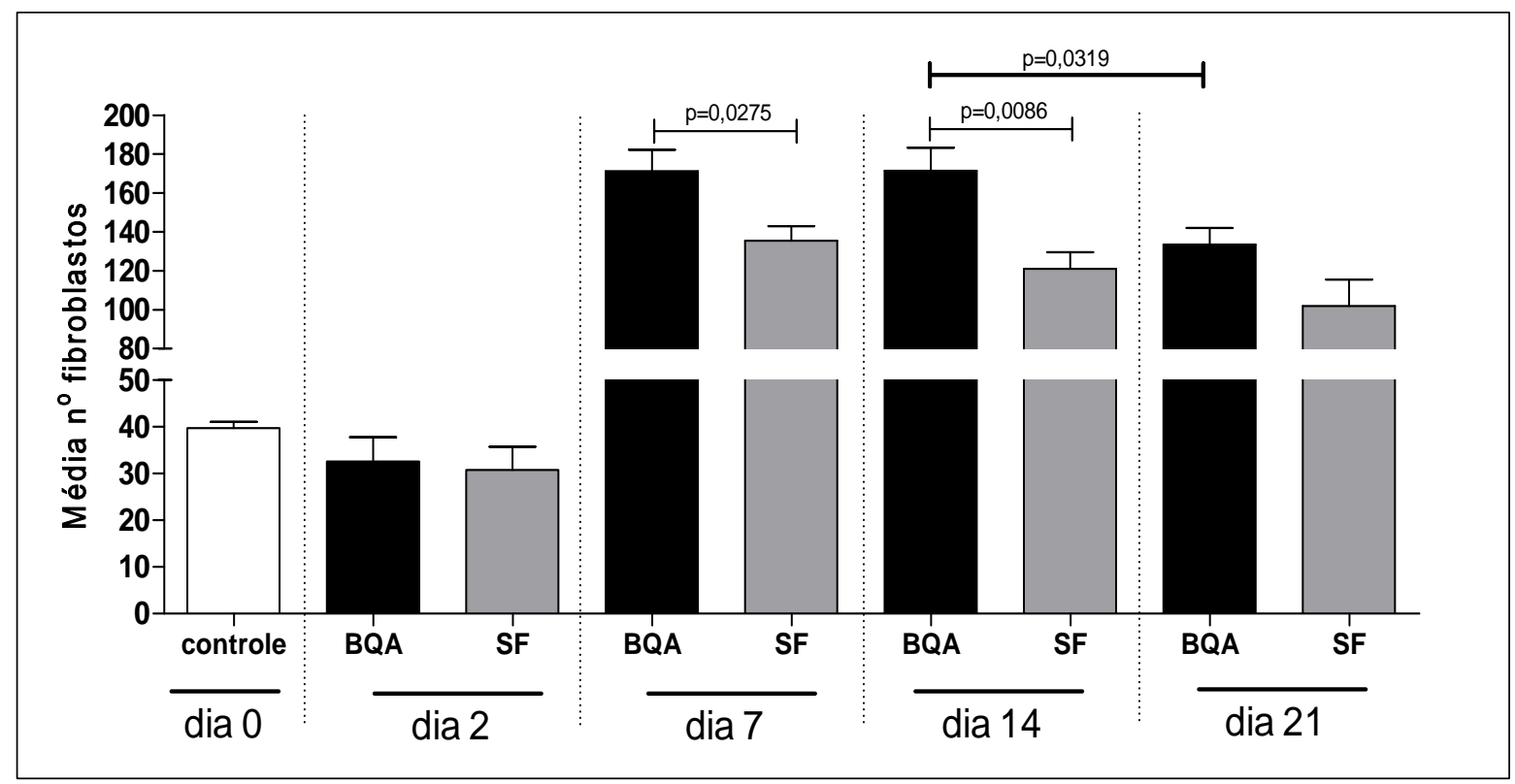

Quantificação dos fibroblastos (por histomorfometria) das úlceras cutâneas tratadas com biomembrana de quitosana-alginato hidratadas com soro fisiológico (BQA) e somente soro fisiológico (SF), por 2, 7, 14 e 21 dias.

Fonte: Caetano (2012) 


\subsection{Avaliação da colagênese}

\subsubsection{Avaliação histológica por análise de imagem}

Pela análise histológica qualitativa por meio da coloração de tricrômio de Gomori, pode-se observar que no $2^{\circ}$ dia ambos os grupos apresentaram pequena quantidade de colágeno. A partir do $7^{\circ}$ dia de seguimento, ambos os grupos obtiveram visível colagênese, sendo mais evidente a presença de fibras mais densas, organizadas e compactas no grupo BQA em relação ao grupo SF (Figura 11).

A quantificação da formação de colágeno, determinada pela porcentagem da área total em azul nas seç̧ões histológicas coradas com tricrômio de Gomori, mostrou que no $2^{\circ}$ dia ambos os grupos apresentaram-se semelhantes e com baixa produção de colágeno. A partir do $7^{\circ}$ dia, foi observado grande quantidade de colágeno em ambos os grupos em relação ao $2^{\circ}$ dia, semelhantes entre si até o $14^{\circ}$ dia. No $21^{\circ}$ dia, foi observada maior porcentagem de colágeno no grupo BQA com diferença estatística em relação ao grupo SF $(p=0,0219)$, conforme apresentado na figura 12. 
Figura 11 - Fotomicrografia da área ulcerada de ambos os grupos ao longo do seguimento

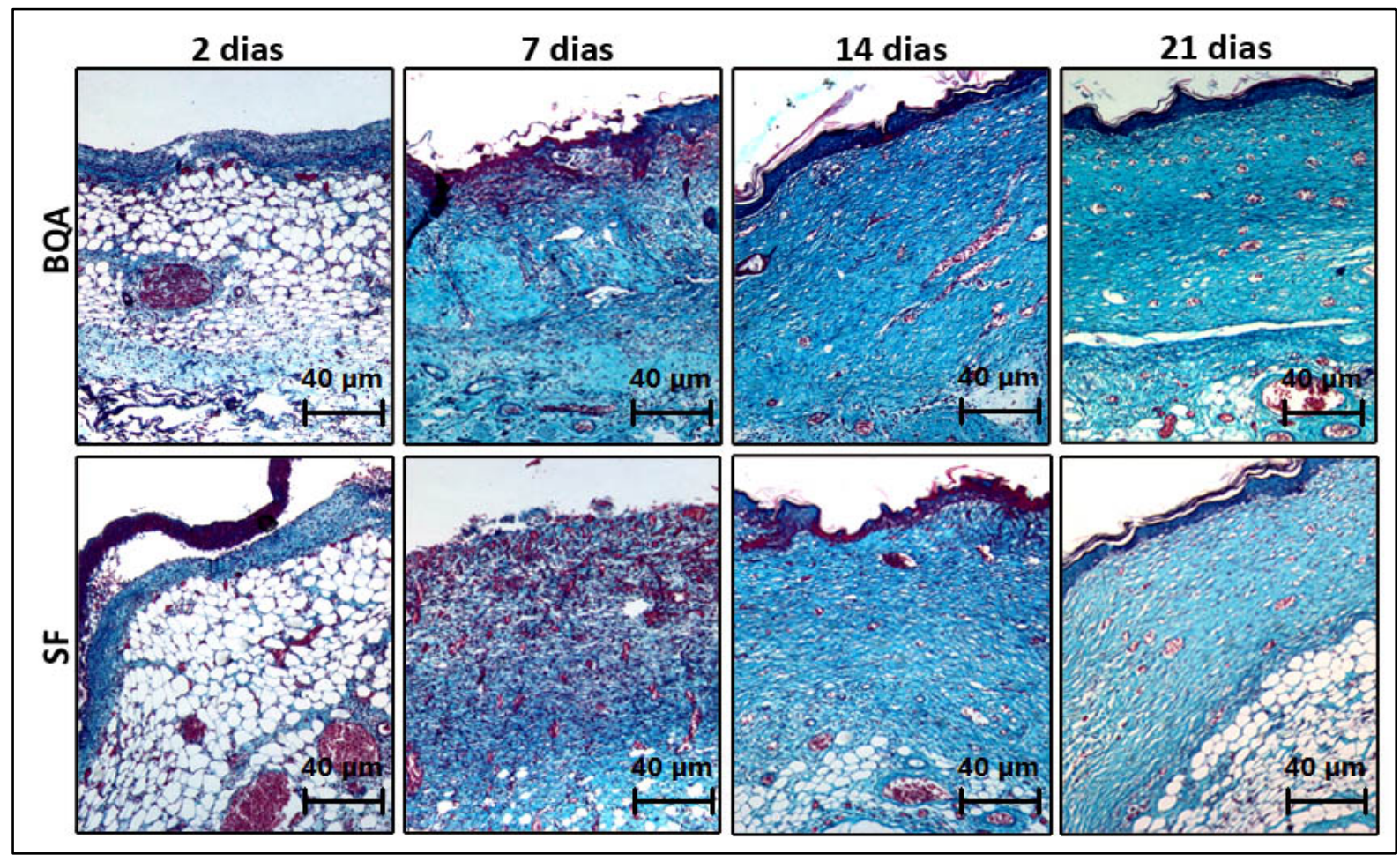

Destaca-se a produção colagênica (coloração azul) nos grupos tratados com biomembrana de quitosana-alginato hidratadas com soro fisiológico (BQA) e somente com soro fisiológico (SF), por $2,7,14$ e 21 dias. Coloração com tricrômio de Gomori.

Fonte: Caetano (2012)

Figura 12- Colagênese nas úlceras cutâneas de ambos os grupos ao longo do seguimento

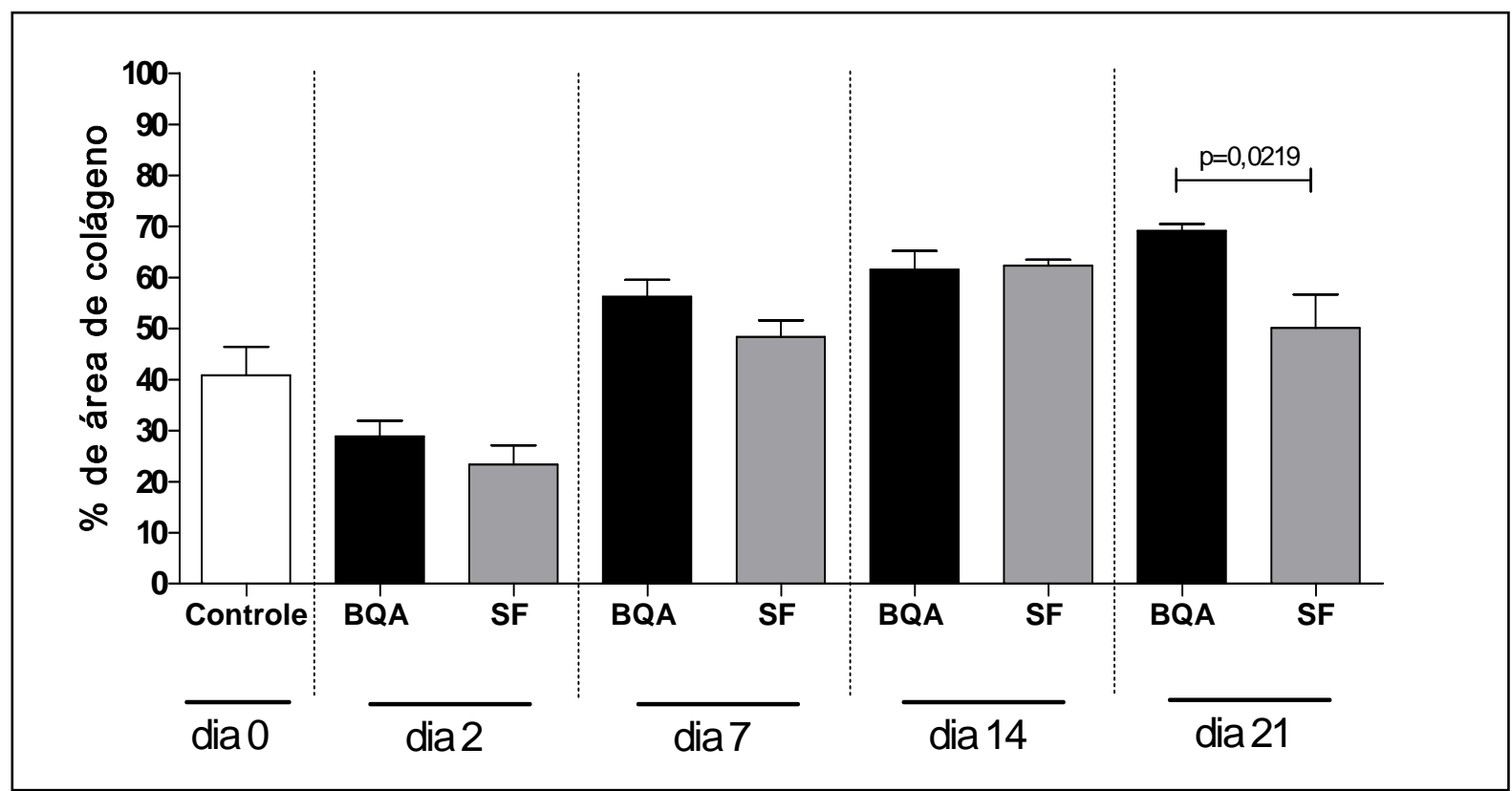

Quantificação do colágeno (por histomorfometria) nas úlceras cutâneas tratadas com biomembrana de quitosana-alginato hidratadas com soro fisiológico (BQA) e somente com soro fisiológico (SF), durante 2, 7, 14 e 21 dias.

Fonte: Caetano (2012) 


\subsubsection{Dosagem de hidroxiprolina (OHP)}

Após a obtenção do peso seco de cada biópsia, as mesmas foram processadas para a análise quantitativa da colagênese por meio da dosagem de hidroxiprolina. Ao final do experimento, realizou-se a leitura de absorbância das microplacas de 96 poços. A partir dos valores de absorbância a $550 \mathrm{~nm}$ das amostras correspondentes à curva padrão, procedeuse à construção da equação da reta e então aos cálculos das concentrações desconhecidas de hidroxiprolina em microgramas por miligrama de tecido seco.

Pode-se verificar na figura 13 que houve aumento progressivo da concentração de hidroxiprolina durante o seguimento das úlceras em todos os grupos de tratamento. $O$ grupo BQA apresentou maior colagênese em relação ao SF no $20(p=0,0042)$ e 210 dia $(p=0,0249)$. No entanto, no 14을 dia o grupo SF apresentou-se superior ao BQA $(p=0,0010)$.

Figura 13 - Colagênese nas úlceras cutâneas de ambos os grupos ao longo do seguimento

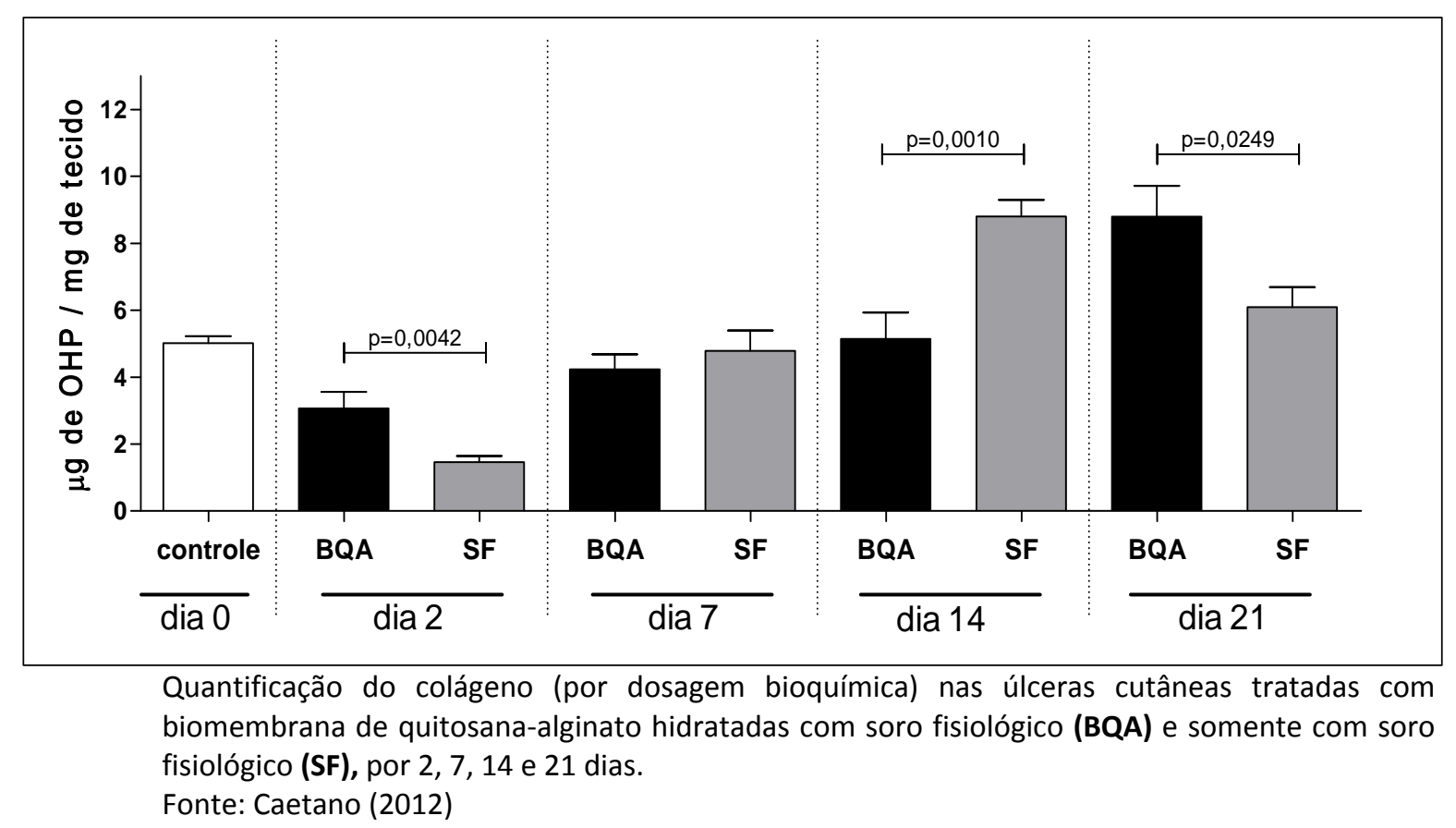




\subsection{Avaliação da reepitelização das úlceras (ICU)}

Para o estudo da reepitelização foi calculado o índice de cicatrização das úlceras (ICU) considerando a área da úlcera (calculada pelo software ImageJ) no início e no último dia de acompanhamento. Comparando a reepitelização dos grupos BQA e SF, no $2^{\circ}$ dia ambos os grupos apresentaram semelhante reepitelização. No $7^{\circ}$ dia, as úlceras do grupo BQA apresentaram maior grau de reepitelização em relação ao grupo $S F(p=0,0006)$. A partir do $14^{\circ}$ dia, a maioria das úlceras de ambos os grupos já estavam totalmente cicatrizadas, embora as do grupo BQA apresentassem maior qualidade de cicatriz e fechamento evidente (Figura 14). 
Figura 14 - Reepitelização das úlceras cutâneas de ambos os grupos ao longo do seguimento

A

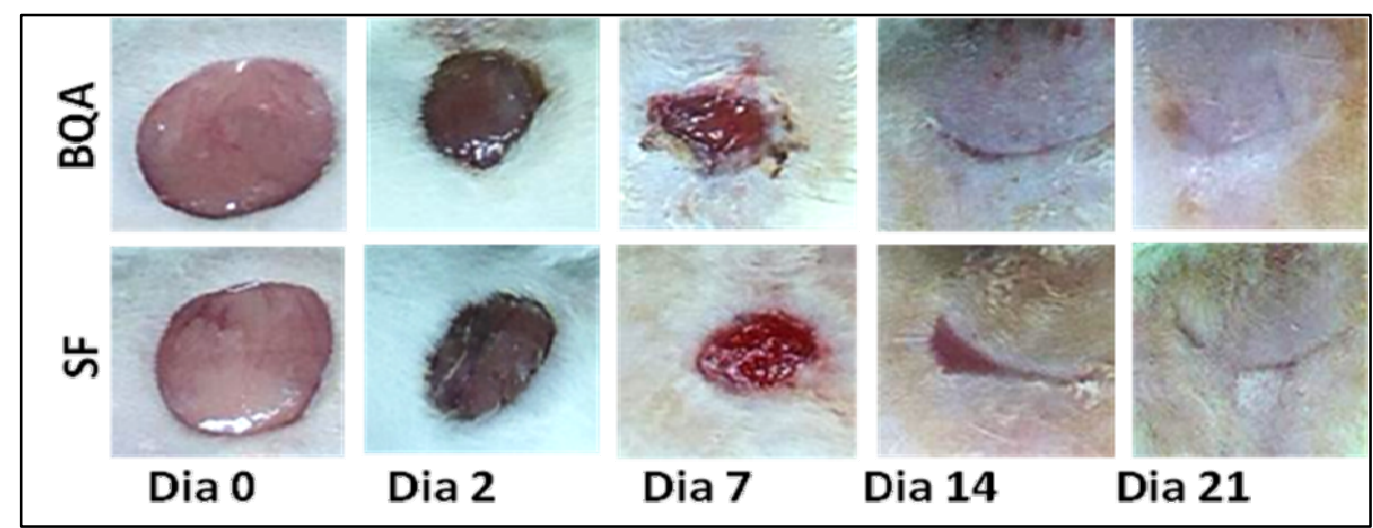

B

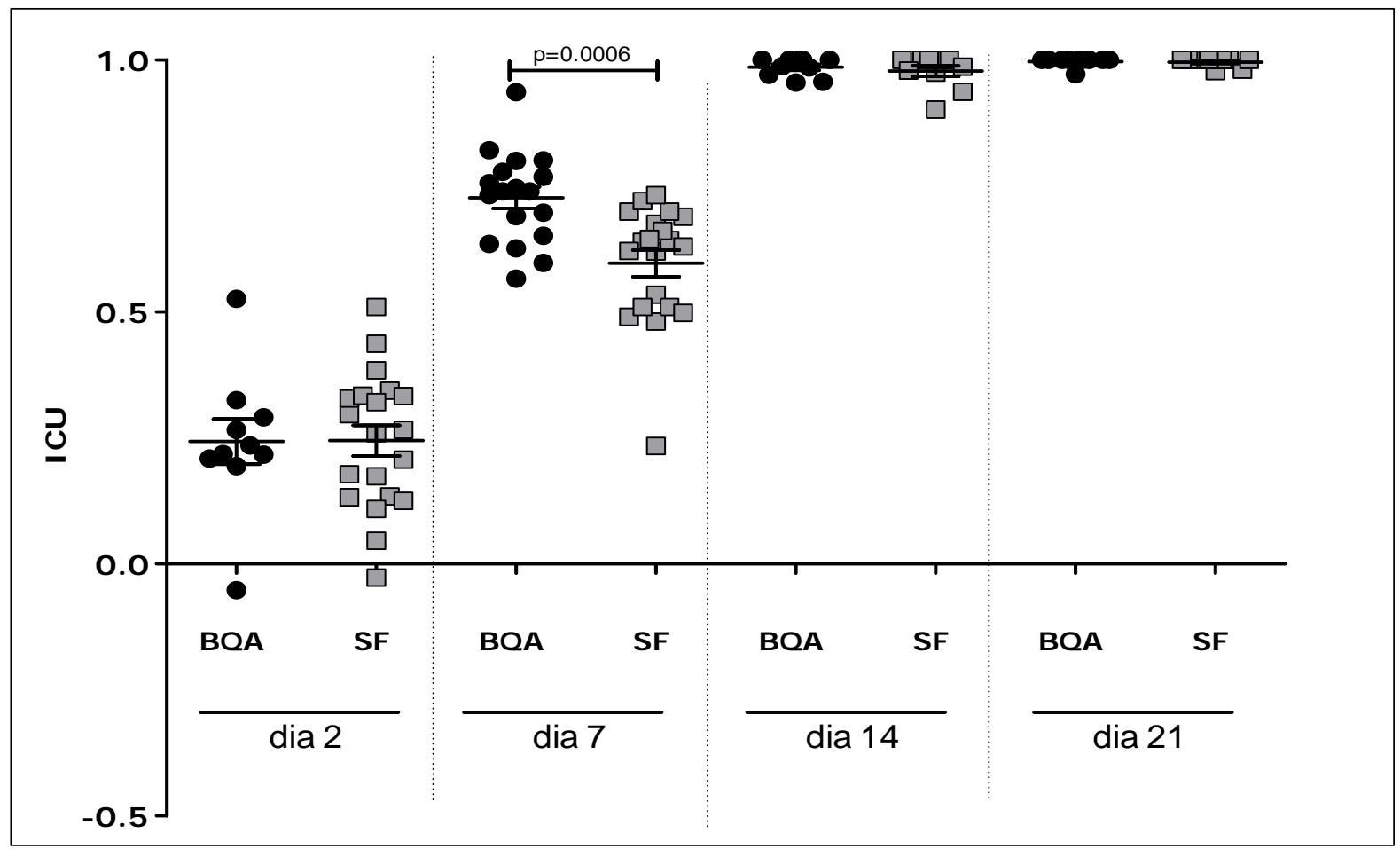

(A) Seguimento clínico das úlceras cutâneas tratadas com biomembrana de quitosana-alginato umidecidas com soro fisiológico (BQA) e somente com soro fisiológico (SF), por 2, 7, 14 e 21 dias de seguimento. (B) Quantificação da reepitelização (pelo índice de cicatrização das úlceras). Fonte: Caetano (2012) 
Considerando o grupo composto por úlceras tratadas somente com gaze, ausente de hidratação e sem troca do curativo (GZ), no 7ํ e 10 dias o grupo BQA e SF apresentaram reepitelização mais evidente em relação à $G Z(p<0,0001)$. No 14임 dia, o grupo $G Z$ ainda encontrava-se em um estado atrasado em relação ao grupo BQA $(p=0,0004)$ e SF $(p=0,0013)$, como apresentado na figura 15.

Figura 15 - Reepitelização das úlceras cutâneas dos três grupos experimentais ao longo do seguimento

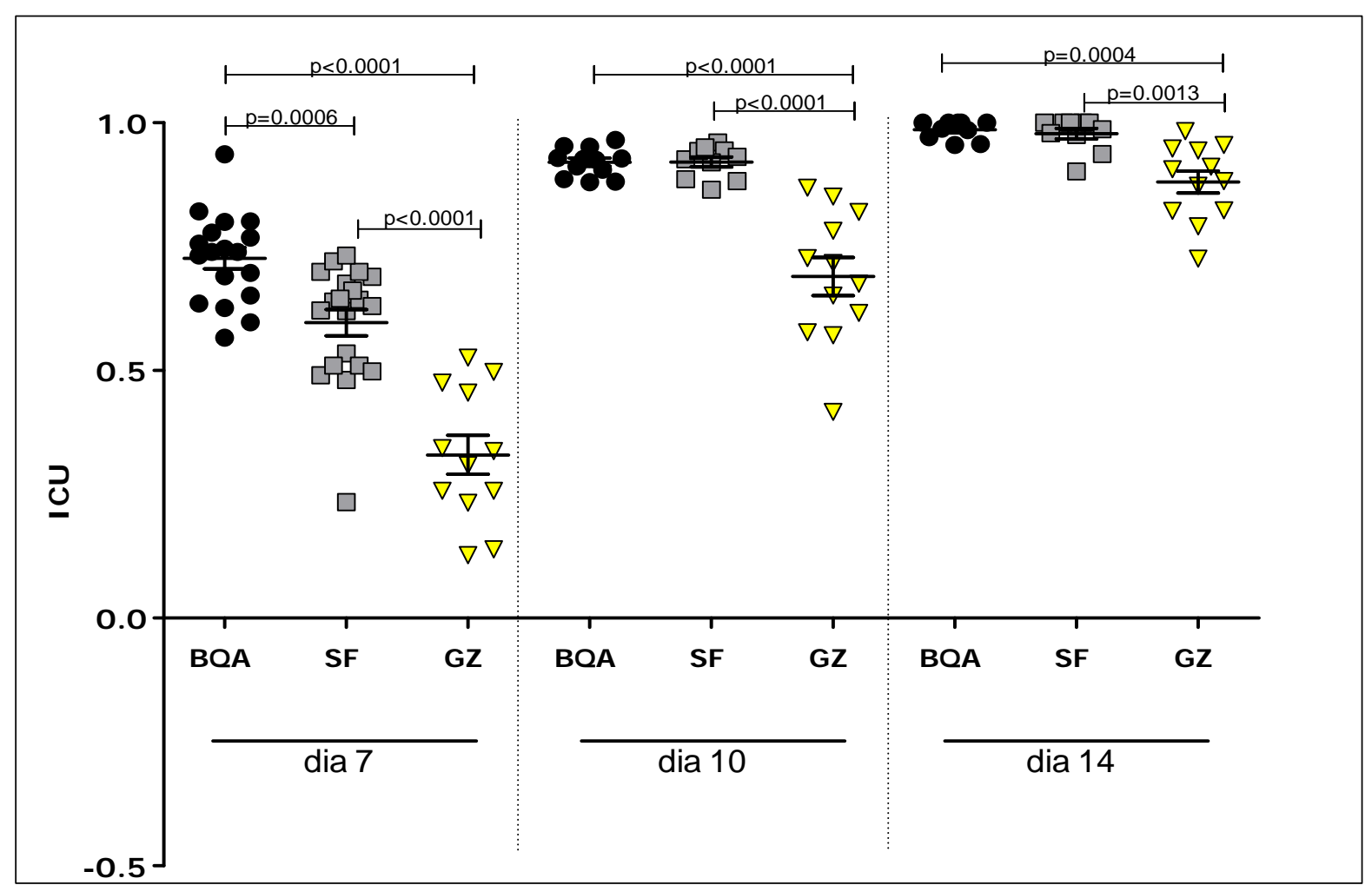

Quantificação da reepitelização (pelo índice de cicatrização das úlceras) das úlceras cutâneas tratadas com biomembrana de quitosana-alginato hidratadas com soro fisiológico (BQA), soro fisiológico (SF) e somente com gaze (GZ), por 7, 10 e 14 dias.

Fonte: Caetano (2012) 
5 Discussão 
Úlceras cutâneas constituem um importante problema de saúde pública que afeta milhões de indivíduos em todo o mundo. A situação agrava-se quando estas úlceras não cicatrizam na forma e tempo esperados, levando à sua cronicidade. Estima-se que em torno de seis milhões de pessoas ao redor do planeta sofram de desordens na cicatrização de úlceras (RANZATO; MARTINOTTI; BURLANDO, 2011).

Diante disso, tem-se desenvolvido diversos estudos visando à busca por diferentes alternativas no tratamento de úlceras cutâneas. Há uma série de trabalhos que reportam propriedades cicatrizantes de produtos naturais (de origem animal ou vegetal). Muitos desses produtos naturais, oriundos do conhecimento popular, ainda não foram devidamente pesquisados, necessitando, assim, de estudos mais abrangentes e acurados (RANZATO; MARTINOTTI; BURLANDO, 2011; SCHULTZ et al., 2011). Dentre esses produtos destaca-se a associação da quitosana com o alginato, formando polímeros utilizados em forma de uma biomembrana.

Apesar dos vários relatos na literatura acerca das importantes propriedades biológicas da quitosana e do alginato utilizados de forma isolada, há poucos relatos sobre a ação conjunta do complexo polieletrolítico de quitosana-alginato na cicatrização cutânea em modelos in vivo (PEI et al., 2008; WANG; KHOR; LIM, 2001).

Alguns trabalhos in vitro relatam a proliferação de diferentes tipos celulares e superior deposição de MEC estimulados por complexos de quitosana-alginato, demonstrando a capacidade de utilização deste biomaterial para estimulação celular. Qi et al. (2011) observaram, comparando com pellets convencionais encontrados no mercado, grande proliferação de células-tronco mesenquimais com alto grau de diferenciação em condrócitos e síntese de MEC utilizando scaffolds de quitosana-alginato. Li e Zhang (2005), por sua vez, relataram superioridade proliferação de condrócitos e intensa deposição de colágeno tipo II.

Levando em consideração a importância do potencial de estímulo à proliferação celular e produção de MEC, a biocompatibilidade e a característica atóxica, a quitosana e o alginato tornaram-se foco de estudos visando uma possível utilização nas úlceras de difícil cicatrização, buscando adotar um melhor método de emprego (cremes, géis, cápsulas, membrana).

Os polímeros de quitosana e de alginato podem ser processados por meio de diferentes metodologias para resultar na produção final de uma biomembrana. Deste modo, 
existem muitos trabalhos na literatura que abordam a obtenção de PECs de quitosanaalginato de diferentes formas, diferentes características, com diferente viabilidade. Muitos são os fatores que podem alterar a eficiência do composto final formado, tais como: a velocidade de agitação na formação, diâmetro do agitador, proporção da quitosana e do alginato utilizados, estabilidade, controle do $\mathrm{pH}$ durante e no final do processo, volumes e tipos de solventes utilizados, etc (OZTURK et al., 2006; PAUL; SHARMA, 2004; RINAUDO, 2008; SAETHER et al., 2008).

Neste estudo foi utilizada, em linhas gerais, a metodologia proposta por Bueno (2010), onde a biomembrana de quitosana-alginato foi prontamente cedida para os testes in vivo. Levando em consideração o potencial de utilização e a necessidade de evidências científicas a respeito dos efeitos do PEC de quitosana-alginato formado, o presente estudo avaliou a eficácia e mecanismos de ação da biomembrana ao longo do processo de cicatrização de úlceras cutâneas em modelo in vivo.

O denso infiltrado inflamatório observado no estudo histológico (HE) do grupo de animais tratados com a biomembrana de quitosana-alginato (BQA) no 20 dia de seguimento pareceu ter favorecido o desbridamento da úlcera ao potencializar a fase inflamatória, além de possivelmente estimular a produção de citocinas e fatores de crescimento que induziriam as fases subsequentes do processo cicatricial.

Pela dosagem de MPO, enzima produzida predominantemente por neutrófilos, indicando o infiltrado neutrofílico, pode-se observar que ambos os grupos apresentaram altas e semelhantes quantidades no 2 o dia (fase inflamatória), indicando que o maior infiltrado inflamatório total do grupo BQA possivelmente seja composto por maiores quantidades de macrófagos e/ou linfócitos, diferente do grupo SF, uma vez que a despolimerização da quitosana estimula o recrutamento de macrófagos funcionais para o local da lesão, o que poderia estar auxiliando a úlcera a estar em um estado mais avançado do processo cicatricial (PAUL; SHARMA, 2004).

No 70 dia houve uma redução importante do infiltrado inflamatório total no grupo BQA em relação ao 2 o dia, assemelhando-se às quantidades celulares do grupo SF, que se manteve semelhante ao 2ㅇ dia, de modo que o processo inflamatório permanecesse constante desde os dias iniciais. Houve também redução da MPO no grupo BQA do 2 para o 70 dia, indicando que BQA regulou a resposta inflamatória reduzindo principalmente os neutrófilos. Entretanto, o grupo SF não apresentou a mesma regulação, mantendo-se com 
alta dosagem neutrofílica no mesmo período, demonstrando intensa participação dos neutrófilos no 70 dia, o que possivelmente explica a inferior atividade cicatrizante deste grupo.

A resposta inflamatória é um passo importante no processo cicatricial, uma vez que prepara o ambiente da úlcera para o processo de reparo. Entretanto, esta fase não deve ser muito intensa e persistente, pois uma resposta tecidual excessiva pode retardar a cicatrização, além de favorecer o distúrbio no equilíbrio entre síntese e degradação de colágeno (ARAÚJO et al., 2010). Observou-se neste presente trabalho que a fase inflamatória foi estimulada, porém não persistente de acordo com as quantidades totais de células iniciais e dosagem neutrofílica do grupo BQA em comparação com SF, o que indica ter sido importante inicialmente e não prejudicial ao longo do seguimento.

Os neutrófilos são muito importantes no processo cicatricial por serem as primeiras células a responder imediatamente após a formação do coágulo. São as primeiras a serem recrutadas para a lesão por serem as células inflamatórias de menor tamanho. No leito da úlcera os neutrófilos, liberam enzimas proteolíticas, tal como MPO, para a digestão de restos celulares e contribuem para a morte de bactérias por meio de fagocitose, produção de superóxido ou peróxido de hidrogênio (espécies reativas derivadas do oxigênio - ROS) e óxido nítrico (NO). Se a descontaminação da úlcera for completa, os neutrófilos entram em apoptose dentro de 48 horas. No entanto, se o estímulo for persistente a função neutrofílica se perpetua produzindo diversas enzimas proteolíticas, o que estimula o estresse oxidativo, prejudicando o processo cicatricial (DOUGHTY; SPARKS-DeFRIESE, 2012; MONACO; LAWRENCE, 2003; STRONCEK; BELL; REICHERT, 2009; FIERRO et al., 1996; FIERRO et al., 1999). Neste sentido, a biomembrana de quitosana-alginato se destaca por estimular iguais quantidades de neutrófilos no 2 o dia, em comparação com o grupo SF, e diminuir drasticamente esta quantidade no 70 dia, diferente do grupo SF que apresentou constante infiltrado neutrofílico do 2ำ para o 7으 dia, o que possivelmente contribuiu para a cicatrização atrasada e deficiente.

Embora as quantidades de células inflamatórias tenham sido semelhantes ao decorrer do seguimento entre os grupos, de acordo com a análise histológica, nota-se que os tipos celulares predominantes foram diferentes. Como esperado, observou-se também que a maior quantidade de células inflamatórias em ambos os grupos foi até o 70 dia, reduzindo após este tempo ao longo do seguimento. 
Diegelmann et al. (1996) fizeram implante subcutâneo de esponja de polivinil álcool associada a quitosana, polímero estimulador celular, em ratos e demonstraram a capacidade de regulação do processo cicatricial comparados com implantes sem quitosana. Os autores observaram uma redução celular significativa nos animais tratados com quitosana no 8o e 14으 dia, enquanto os animais do grupo controle apresentavam elevadas quantidades de macrófagos, leucócitos, vasos sanguíneo e produção de colágeno. Os resultados deste presente estudo condizem parcialmente com os citados acima, uma vez que no mesmo período de análise houve maior fibroplasia nos animais tratados com quitosana-alginato, enquanto que reduziu as células inflamatórias. O aparecimento dos fibroblastos não reportados por Diegelmann et al. (1996), porém quantificados neste estudo seriam os responsáveis por maior colagênese observada no período.

A redução do infiltrado inflamatório em ambos os grupos foi acompanhada por proliferação e migração de grandes quantidades de fibroblastos, principalmente no grupo BQA no 7ㅇ e 14을 dia, sendo esses eventos importantes para as fases de formação tecidual e posterior remodelamento do novo colágeno sintetizado.

Kosaka et al. (1996) também utilizaram implante de quitosana em cães para análise do estimulo celular originado pela quitosana por meio de quimiluminescência. Relataram que uma grande quantidade de macrófagos permaneceu por mais tempo no tecido dos animais que receberam quitosana, sugerindo um potente papel imunoprotetor destas células, modulando a migração, atividade e subsequentes processos de fibroplasia e reepitelização, o que possivelmente poderia estar ocorrendo no processo de cicatrização dos animais que receberam a biomembrana de quitosana-alginato, de acordo com o estímulo celular observado em todo processo, resultando na acelerada e eficaz cicatrização observada neste presente estudo.

A importância da angiogênese está relacionada com a intensa necessidade de nutrientes e oxigênio para o local especificamente durante a fase inflamatória, momento em que as células estão em alto gasto energético devido às intensas mitoses e ativação celular para o desbridamento tecidual (BATES; JONES, 2003). Como esperado, o aumento da angiogênese aconteceu após os primeiros dias, de modo que no 7으 dia houve maior quantidade em ambos os grupos mesmo não havendo diferença estatística entre eles. Dai et al. (2009) relataram por meio de método histológico menor presença de vasos sanguíneos em animais tratados com um curativo poroso (em forma de esponja) de quitosana e 
alginato, observando que os animais tratados somente com gaze encontravam-se em um estado de granulação atrasada e com presença pronunciada de vasos sanguíneos. Ambos os trabalhos utilizaram apenas o método histológico para avaliação da angiogênese, sendo necessário o emprego de outros métodos para averiguar o estímulo a este evento, uma vez que a quitosana possivelmente tem a capacidade de aumentar o aparecimento de novos vasos sanguíneos, por meio de citocinas (MUZZARELLI, 2009).

Neste sentido, Dash et al. (2011) demonstraram que a quitosana tem papel importante na liberação de fator de crescimento para fibroblasto-2 (FGF-2) que, além da fibroplasia, estimula a angiogênese ativando células endoteliais. Hao et al. (2007) e Sun et al. (2010) demonstraram aumento da angiogênese em animais tratados com aplicação de VEGF, sendo este um possível fator de crescimento também estimulado pela quitosana em lesões de pele para o brotamento rápidos de novos vasos sanguíneos. Neste presente estudo, corroborando com Dai et al. (2009), a angiogênese não foi pronunciada de acordo com o método empregado para análise. Entretanto, houve estímulo e regulação em todas as fases do processo cicatricial com ênfase no remodelamento do novo colágeno produzido.

O colágeno é o principal componente estrutural do tecido de granulação, fortalece a MEC e, finalmente, irá repor a matriz provisória de fibrina. O aminoácido prolina é uma parte integral da fibra de colágeno e a hidroxiprolina é usada como um marcador bioquímico para o colágeno tecidual, assim como um indicativo positivo da progressão da cicatrização (KOKANE et al., 2009; NAYAK et al., 2011). A presença de fibras de colágeno mais organizadas e maduras observadas no grupo BQA somada ao aumento do conteúdo de hidroxiprolina, sugere a efetividade do complexo polieletrolítico utilizado na proliferação fibroblástica e síntese de MEC durante a cicatrização, propriedades estas semelhantes às observadas por Dai et al. (2009) e Araújo et al. (2010).

A colagênese, por meio da dosagem OHP mostrou-se superior no início e no final do processo no grupo BQA, com predominância de fibroblastos. Entretanto, observou uma grande colagênese no 14ำ dia de seguimento no grupo SF, quando as úlceras já encontravam praticamente reepitelizadas. A partir do 14 을 dia, período de redução da fibroplasia, houve um intenso aparecimento de colágeno no grupo BQA. Estes resultados sugerem estímulos em tempos diferentes para a produção predominante de colágeno, sendo necessários estudos mais aprofundados sobre os tipos de colágenos formados em ambos os grupos, uma vez que a qualidade parece ter sido melhor no grupo BQA. Assim, o aparecimento de um 
colágeno mais denso e fibras mais organizadas no grupo BQA, como observado no método histológico, sugere papel importante do biomaterial no leito da lesão em todas as fases da cicatrização, corroborando com a literatura.

De acordo com o trabalho de Wang et al. (2002), o complexo de quitosana-alginato parece facilitar o remodelamento do tecido cicatrizado, aumentando a taxa de síntese e compactação do novo colágeno formado, bem como o aparecimento de fibroblastos maduros, como observado no 21을 dia de seguimento no grupo BQA deste presente trabalho.

Além da biomembrana de quitosana-alginato estimular a fase de proliferação e remodelamento teciduais e a ativação da fase inflamatória, certamente atuaram intensamente na produção de citocinas e fatores de crescimento, evidentemente favorecendo as fases subsequentes da cicatrização como também proposto por Imamura et al. (2005) e Andrade et al. (2011). Nesse sentido Khan e Peh (2003) sugerem que a utilização da quitosana para o tratamento de úlceras cutâneas influencia beneficamente todas as fases da cicatrização. A rápida proliferação dos fibroblastos (fibroplasia) estaria envolvida com a liberação de IL-8 pelo próprio fibroblasto induzida pela quitosana. Este efeito somado a síntese de colágeno e contração da úlcera modulada pela quitosana, resultou em um rápido fechamento da lesão.

Há relatos na literatura a respeito do processo cicatricial ser beneficiado pela umidade do leito da úlcera. Nesse sentido, biomateriais que aumentam a humidade da úlcera favorecem também por este motivo a cicatrização mais eficaz, como por exemplo, a biomembrana de látex da seringueira Hevea brasiliensis (FRADE et al., 2011; FRADE et al., 2012, ANDRADE et al., 2011). Diante disso, objetivou-se no presente trabalho adicionar um grupo de estudo que recebeu somente o curativo com gaze e esparadrapo nas úlceras cutâneas (grupo GZ) e assim permaneceu durante todo seguimento para avaliação da reepitelização e comparar com os grupos do estudo.

Wang et al. (2002) relataram a propriedade cicatrizante de uma biomembrana de quitosana-alginato utilizada como tratamento de úlceras dorsais em ratos, comparando com ratos ulcerados sem o tratamento (somente gaze) e ratos ulcerados tratados com um curativo convencional já utilizado comercialmente (Opsite $\left.{ }^{\circledR}\right)$. Todos receberam curativo secundário a base de gaze. A reepitelização das úlceras tratadas com a biomembrana foi de aproximadamente $60 \%$ no 70 dia, corroborando com os resultados encontrados neste 
presente trabalho, onde apresentou uma reepitelização de aproximadamente $70 \%$ em igual período de análise, equiparando-se com o curativo comercial.

Assim como também observado por Wang et al. (2002) e Dai et al. (2009) em úlceras tratadas somente com gaze, a aderência das fibras da mesma no tecido em formação prejudicava as trocas dos curativos, resultando em danos secundários à úlcera e perda de tecido, fato que não é presenciado em úlceras tratadas com biomembrana ou biofilme, isolando totalmente a úlcera do curativo secundário, não necessitando trocar constantemente.

A umidade no leito da úlcera facilita o desbridamento autolítico, ou seja, a degradação natural do tecido desvitalizado por meio de ação enzimática, e a mobilidade celular. É proposto que a hidratação da úlcera estimule a formação do tecido de granulação para posterior reepitelização, além de atrair fibroblastos e estimular a síntese e remodelamento do colágeno. Além disso, evita a desidratação tecidual diminuindo possíveis traumatismos durante a troca diária dos curativos (KUMAR et al., 2008; NARDI et al., 2004).

A oclusão das lesões com gaze e esparadrapo sem trocas diárias apresentou-se prejudicial quando comparados com os grupos BQA e SF. A ausência de umidificação somada com a utilização de um curativo não ativo que se adere com o tecido em formação atrapalhou o processo cicatricial, observando úlceras em grau atrasado quanto à reepitelização no 14을 dia, diferente do grupo BQA e SF. Isso evidencia a importante atividade cicatrizante da biomembrana de quitosana-alginato hidratada com soro fisiológico 0,9\% frente aos demais tratamentos estudados. 


\section{Fonclusões}


\& Os achados deste trabalho indicam que a utilização do PEC de quitosana-alginato desempenha um papel importante no recrutamento e organização celular, corroborando, assim, os resultados reportados por outros autores;

A biomembrana de quitosana-alginato parece regular as fases da cicatrização, principalmente a proliferação e recrutamento de neutrófilos, fibroblastos, síntese e remodelamento do colágeno;

A regulação dos componentes da cicatrização proporcionada pelos polissacarídeos naturais, somada à proteção não aderente ao ambiente ulcerado pela biomembrana, acelerou a cicatrização de úlceras agudas em ratos. 


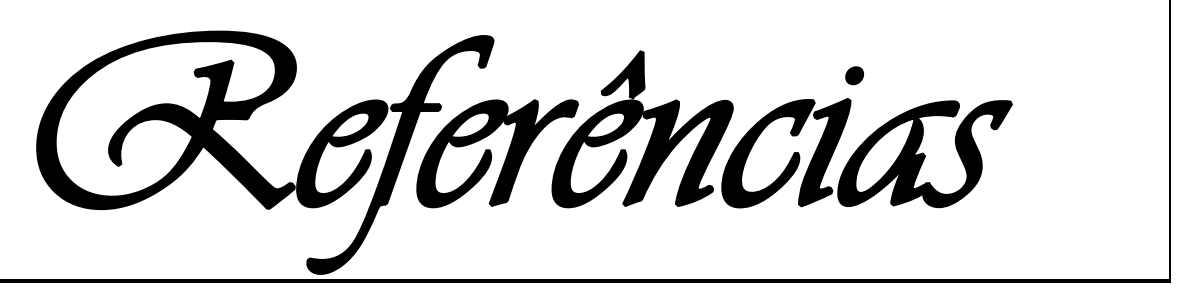




\section{REFERÊNCIAS}

ABREU, E.S.; MARQUES, M.E.A. Histologia da pele normal. In: JORGE, S.A.; DANTAS, S.R.P.E. Abordagem multiprofissional do tratamento de feridas. São Paulo: Atheneu, 2005. p. 17-29.

ALEMDAROGLU, C.; DEGIM, Z.; ÇELEBI, N.; ZOR, F.; ÖZTÜRK, S.; ERDOGAN, D. An investigation on burn wound healing in rats with chitosan gel formulation containing epidermal growth factor. Burns, v. 32, n. 3, p. 319-327, 2006.

ANAL, A. K.; STEVENS, W. F. Chitosan-alginate multilayer beads for controlled release of ampicilin. International Journal of Pharmaceutics, v. 290, n. 1-2, p. 45-54, 2005.

ANDRADE, T. A.; IYER, A.; DAS, P. K.; FOSS, N. T.; GARCIA, S. B.; COUTINHO-NETTO, J.; JORDÃO-JR, A. A.; FRADE, M. A. C. The inflammatory stimulus of a natural latex biomembrane improves healing in mice. Brazilian Journal of Medical and Biological Research, v. 44, n. 10, p. 1036-47, 2011.

ARAÚJO, L. U.; GRABE-GUIMARÃES, A.; MOSQUEIRA, V. C. F.; CARNEIRO, C. M.; SILVABARCELLOS, N. M. Profile of wound healing process induced by allantoin. Acta Cirúrgica Brasileira, v. 25, n. 5, p. 460-466, 2010.

ARNOLD, F.; WEST, D. Angiogenesis in wound healing In: Pharmacology \& Therapeutics. Oxford. v. 52. 1991. p. 407-422.

AZEVEDO, V. V. C.; CHAVES, S. A.; BEZERRA, D. C.; LIA FOOK, M. V.; COSTA, A. C. F. M. Quitina e quitosana, aplicações como biomateriais. Revista Eletrônica de Materiais e Processos, v.2.3, p. 27-34, 2007.

BARANOSKI, S.; AYELLO, E. A. Wound Care Essentials. $1^{\circ}$ Ed. Pennsylvania: Lippincott Williams \& Wilkins, 2004. 487 p.

BATES, D. O.; JONES, O. P. The role of vascular endotelial growth fator in wound healing. Lower extremity wounds, v. 2, n. 2, p. 107-120, 2003.

BAUM, C. L.; ARPEY, C. J. Normal cutaneous wound healing: clinical correlation with cellular and molecular events. Dermatologic Surgery, v. 31, n. 6, p. 674-686, 2005.

BEANES, S. R.; DANG, C.; SOO, C.; TING, K. Skin repair and scar formation: the central role of TGF- $\beta$. Expert reviews in molecular medicine, v.5, p.1-11, 2003.

BELLO, Y. M.; PHILLIPS, T. J. Recent advances in wound healing. Journal of the American Medical Association, v. 283, n. 6, p. 716-718, 2000.

BRADDING, P.; WALLS, A.; CHURCH, M. Mast cells and basophils: their role in initiating and maintaining inflammatory responses. In: HOLGATE, S. Immunopharmacology of the Respiratory System. New York: Academic Press; 1995. p. 53-84.

De acordo com: ASSOCIAÇÃO BRASILEIRA DE NORMAS TÉCNICAS. NBR 6023: informação e documentação: referências: elaboração. Rio de Janeiro, 2002. 
BROUGHTON II, G.; JANIS; J. E.; ATTINGER, C. E. Wound healing: an overview. Plastic and Reconstructive Surgery, v. 117, n. 7, p. 1e-S-32e-S, 2006.

BUENO, C. Z. Influência do tipo de estratégia de reforço das propriedades mecânicas nas características de membranas de quitosana e alginato projetadas para o recobrimento de lesões de pele. 2010. 114 f. Dissertação (Mestrado em engenharia química). Faculdade de Engenharia Química - Desenvolvimento de Processos Biotecnológicos, Universidade Estadual de Campinas, São Paulo, 2010.

CAETANO, G. F. Biomembrana de quitosana-alginato na cicatrização de úlceras cutâneas em ratos. 2012. 88 f. Dissertação (Mestrado em Biotecnologia) - Instituto de Ciências Biomédicas, Universidade de São Paulo, São Paulo, 2012.

CAETANO, K. S.; FRADE, M. A. C.; MINATEL, D. G.; SANTANA, L. A.; ENWEMEKA, C. S. Phototherapy improves healing of chronic venous ulcers. Photomedicine \& Laser Surgery, Larchmont, v.27, n. 1, p. 111-118, 2009.

CAMPOS, A. C.; GROTH, A. K.; BRANCO, A. B. Assessment and nutritional aspects of wound healing. Current Opinion in Clinical Nutrition \& Metabolic Care. v.11, n. 3, p. 281-288, 2008.

CANDI, E.; SCHMIDT, R.; MELINO, G. The cornified envelope: a model of cell death in the skin. Nature Reviews Molecular Cell Biology, v. 6, p. 328-340, 2005.

CÁRDENAS, A.; ARGUELLES-MONAL, W.; GOYCOOLEA, F. M.; HIGUERA-CIAPARA, I.; PENICHE, C. Diffusion through membranes of the polyelectrolyte complex of chitosan and alginate. Macromolecular Bioscience, v. 3, n. 10, p. 535-539, 2003.

CHANG, H. Y.; CHI, J.; DUDOIT, S.; BONDRE, C.; RIJN, M. V. D.; BOTSTEIN, D.; BROWN, P. O. Diversity, topographic differentiation, and positional memory in human fibroblasts. Proceedings of National Academy of Science, v. 99, n. 20, p. 12877-12882, 2002.

CLARK, R. A. F.; GHOSH, K.; TONNESEN, M. G. Tissue engineering for cutaneous wounds. Journal of Investigative Dermatology, v. 127, p. 1018-1029, 2007.

CLASEN, C.; WILHELMS, T.; KULICKE, W. M. Formation and characterization of chitosan membranes. Biomacromolecules, v. 7, n. 11, p. 3210-3222, 2006.

CORSETTI, G.; D'ANTONA, G.; DIOGUARDI, F.S.; REZZANI, R. Topical application of dressing with aminoacids improves cutaneous wound healing in aged rats. Acta histochemica, v. 112, n. 5, p. 497-507, 2009.

DAI, M.; ZHENG, X.; XU, X.; KONG, X.; LI, X.; GUO, G.; LUO, F.; ZHAO, X.; QUANWEI, Y.; QIAN, Z.. Chitosan-Alginate Sponge: preparation and application in curcumin delivery for dermal wound healing in rat. Journal of Biomedicine and Biotechnology, v. 2009, p. 1-8, 2009. 
DALLAN P. R. M. Síntese e caracterização de membrana de quitosana para regeneração de pele. Campinas, SP. 2005. 212 f. Tese (Doutorado em Engenharia Química) - Faculdade de Engenharia Química, Universidade Estadual de Campinas, 2005.

DASH, M.; CHIELLINI, F.; OTTENBRITE, R. M.; CHIELLINI, E. Chitosan-A versatile semisynthetic polymer in biomedical applications. Progress in Polymer Science, v. 36, n. 8, p. 981-1014, 2011.

DIEGELMANN, R. F.; DUNN, J. D.; LINDBALD, W. J.; COHEN, I. K. Analysis of the effects of chitosan on inflammation, angiogenesis, fibroplasia, and collagen deposition in polyvinyl alcohol sponge implants in rat wounds. Wound repair and regeneration, v. 4, n. 1, p. 48-52, 1996.

DIEGELMANN, R. F.; EVANS, M. C. Wound healing: an overview of acute, fibrotic and delayed healing. Frontiers in Bioscience, v. 1, p. $283-289,2004$.

DONG, Z.; WANG, Q.; DU, Y. Alginate/gelation blend films and their properties for drug controlled release. Journal of Membrane Science, v. 280, n. 1, p. 37-44, 2006.

DOUGHTY, D.B; SPARKS-DeFRIESE, B. Wound healing physiology. In: BRYANT, R.A.; NIX, D.P. Acute and chronic wounds. Current management concepts. 4th ed. Missouri: Elsevier Mosby, 2012. cap.4, p.63-82.

EHRENREICH, M.; RUSZCZAK, Z. Update on Tissue-Engineered Biological Dressings. Tissue Engineering, v. 12, n. 9, p. 2407-2424, 2006.

ELIAS, P. M.; MENON, G. K. Structural and lipid biochemical correlates of the epidermal permeability barrier. Advances in Lipid Research, v. 24, p. 1-26, 1991.

ELIAS, P. M. The skin barrier as an innate immune element. Seminars in Immunopathology, v. 29, p. 3-14, 2007.

FALANGA, V. Wound healing and its impairment in the diabetic foot. Lancet, v. 366, n. 9498, p. 1736-43, 2005.

FAZIO, M. J.; ZITELLI, J. A.; GOSLEN, J. B. Cicatrização de feridas. In: Coleman III WP, Hanke $\mathrm{CW}$, Alt TH, Asken S. Cirurgia Cosmética - Princípios e Técnicas. 2.ed. Rio de Janeiro: Revinter, 2000. p. 18-23.

FERRARA, N. Vascular endothelial growth factor and the regulation of angiogenesis. Recent Progress in Hormone Research, v. 55, p. 15 - 35, 2000.

FIERRO, I. M.; BARJA-FIDALGO, C.; CUNHA, F. Q.; FERREIRA, S. H. The involvement of nitric oxide in the anti-candida albicans activity of rat neutrophils. Immunology, v. 89, n. 2, p. 295300, 1996. 
FIERRO, I. M.; NASCIMENTO-DASILVA, V.; ARRUDA, M. A.; FREITAS, M. S.; PLOTKOWSKI, M. C.; CUNHA, F. Q.; BARJA-FIDALGO, C. Induction of nos in rat blood pmn in vivo and in vitro: modulation by tyrosine kinase and involvement in bactericidal activity. Journal of Leukocyte Biology, v. 65, n. 4, p. 508-514, 1999.

FONDER, M. A.; LAZARUS, G. S.; COWAN, D. A.; ARONSON-COOK, B.; KOHLI, A. R.; MAMELAK, A. J. Treating the chronic wound: a practical approach to the care of non healing wounds and wound care dressings. Journal of the American Academy of Dermatology, v. 58, n. 2, p. 185206, 2008.

FRADE, M. A. C; COUTINHO-NETTO, J.; GOMES, F. G.; MAZZUCATO, E. L.; ANDRADE, T. A.; FOSS, N. T. Natural-biomembrane dressing and hypersensitivity. Anais Brasileiros de Dermatologia, v. 86, n. 5, p. 885-91, 2011.

FRADE, M. A. C.; ASSIS, R. V. C.; COUTINHO-NETTO, J.; ANDRADE, T. A. M.; FOSS, N. T. The vegetal biomembrane in the healing of chronic venous ulcers. Anais Brasileiros de Dermatologia, v. 87, n. 1, p. 45-51, 2012.

FRADE, M. A. C. Úlcera de perna: caracterização clínica e perfil imunohistopatológico da cicatrização na presença da biomembrana de látex natural da seringueira Hevea brasiliensis. 2003. $164 \mathrm{f}$. Tese (Doutorado em Medicina pela Clínica Médica) - Faculdade de Medicina de Ribeirão Preto, Universidade de São Paulo, Ribeirão Preto, 2003.

FUKAI, F.; SUZUKI, H.; SUZUKI, K.; TSUGITA, A.; KATAYAMA, T. Rat plasma fibronectin contains two distinct chemotactic domains for fibroblastic cells. The Journal of Biological Chemistry, v. 266, p. 8807-13, 1991.

GÁL, P.; VASILENKO, T.; KOSTELNÍKOVÁ, M.; JAKUBCO, J.; KOVÁC, I.; SABOL, F.; ANDRÉ, S.; KALTNER, H.; GABIUS, H.; SMETANA JR, K. Open Wound Healing In Vivo: Monitoring Binding and Presence of Adhesion/Growth-Regulatory Galectins in Rat Skin during the Course of Complete Re-Epithelialization. Acta Histochem Cytochem, v. 44, n. 5, p. 191-199, 2011.

GARY-SIBBALD, R.; WOO, K. The biology of chronic foot ulcers in persons with diabetes. Diabetes Metabolism Research and Reviews, v. 24, n. 1, p. 25-30, 2008.

GEORGE, M.; ABRAHAM T. E. Polyionic hydrocolloids for the intestinal delivery of protein drugs: alginate and chitosan - a review. Journal of Controlled Release, v. 114, n. 1, p. 1-14, 2006.

GOLDMAN, R. Growth factors and chronic wound healing: past, present and future. Adv Skin Wound Care, v. 17, n. 1, p. $24-35,2004$.

GOMES, M. E.; SIKAVITSAS, V. I.; BEHRAVESH, E.; REIS, R. L.; MIKOS, A. G. Effect of flow perfusion on the osteogenic differentiation of bone marrow stromal cells culture on starchbased threedimensional scaffolds. Journal Biomedical Materials Research, v. 67, n. 1, p. 8795, 2003. 
GONÇALVES, R. O.; SILVA, E. M.; MARQUES, T. C.; LOPES FILHO, G. J. Avaliação histoquímica quantitativa do colágeno na fascia transversalis e na bainha anterior do músculo reto abdominal em doentes com hérnia inguinal. Revista do Colégio Basileiro de Cirurgiões, v. 30, n. 4, p. 286-292, 2003.

GOSAIN, A.; DIPIETRO, L.A. Aging and wound healing. World Journal of Surgery, v. 28, n. 3, p. 321-326, 2004.

GRINELL F. Fibroblast biology in three-dimensional collagen matrices. Trends in Cell Biology, v. 13, n. 5, p. 264-9, 2003.

GUO, S.; DIPIETRO, L.A. Factor affecting wound healing. Journal of Dental Research, v. 89, n. 3, p. 219-229, 2010.

GURTNER, G. C.; WERNER, S.; BARRANDON, Y.; LONGAKER, M. T. Wound repair and regeneration. Nature, v. 453, p. 314-321, 2008.

HAO, X.J.; SILVA, E. A.; MANSSON-BROBERG, A.; GRINNEMO, K. H.; SIDDIQUI, A. J.; DELLGREN, G.; WARDELL, E.; BRODIN, L. A.; MOONEY, D. J.; SYLVEN, C. Angiogenic effects of sequential release of VEGFA(165) and PDGF-BB with alginate hydrogels after myocardial infarction. Cardiovascular Research, n. 75, p. 178-85, 2007.

HARDING, K.G.; PATEL, M.G.K. Science, medicine and the future: Healing chronic wounds. British Medical Journal, v. 324, p. 160-163, 2002.

HART, J. Inflammation. 1: its role in the healing of acute wounds. Journal of Wound Care, v. 11, n. 6, p. $205-209,2002$.

HEDLUND C. S. Cirurgia do sistema tegumentar. In: FOSSUM W. T., HEDLUND C.S, HULSE D., JOHNSON A. L., SEIM H. B., WILLARD M. D. \& CARROLL G.L. (Eds). Cirurgia de Pequenos Animais. 5.ed. São Paulo: Roca, 2002. p. 101-162.

HEIN, S.; WANG, K.; STEVENS, W. F.; KJEMS, J. Chitosan composites for biomedical applications: status, challenges and perspectives. Materials Science and Technology, v. 24, n. 9, p. 1053-1061, 2008.

HENG, M. C. Y. Wound healing in adult skin: aiming for perfect regeneration. International Journal of Dermatology, n. 50, n. 9, p. 1058-1066, 2011.

HOUBEN, E.; DE PAEPE, K.; ROGIERS, V. A keratinocyte's course of life. Skin Pharmacology and Physiology, v. 20, n. 3, p. 141-147, 2007.

HOWELL-JONES, R. S.; WILSON, M. J.; HILL, K. E.; HOWARD, A. J.; PRICE, P. E.; THOMAS, D. W. A review of the microbiology antibiotic usage and resistance in chronic skin wounds. Journal of Antimicrobial Chemotherapy, v. 55, p. 143-149, 2005. 
HUANG, Y.; REN, L.; QIN, Y. Observation of cicatricial fibroblasts in culture and its biological properties. Zhongguo Xiu Fu Chong Jian Wai Ke Za Zhi, v. 12, n. 6, p. 332-5, 1998.

IMAMURA, M.; OGAWA, T.; SASAGURI, Y.; CHAYAMA, K.; UENO, H. Suppression of macrophage infiltration inhibits activation of hepatic stellate cells and liver fibrogenesis in rats. Gastroenterology, v. 128, p. 138-146, 2005.

JAUL, E. Non-healing wounds: the geriatric approach. Archives of Gerontology Geriatrics, v. 49, n. 2, p. 224-6, 2009.

JUNQUEIRA, L. C.; CARNEIRO, J. Histologia Básica. 10th. Rio de Janeiro. Guanabara Koogan S.A. 2004.488 p.

KARAKEÇILI, A. G.; SATRIANO, C.; GÜMÜŞDERELIOĞLU, M.; MARLETTA, G. Surface characteristics of ionically crosslinked chitosan membranes. Journal of Applied Polymer Science, v. 106, p. 3884-3888, 2007.

KARUKONDA, S. R; FLYNN, T. C.; BOH, E. E.; MCBURNEY, E. I.; RUSSO, G. G.; MILLIKAN, L. E. The effects of drugs on wound healing - part ii. Especific classes of drugs and their effect on healing wounds. International Journal of Dermatology, v. 39, n. 5, p. 321-333, 2000.

KHAN, T. A.; PEH, K. K. A preliminary investigation of chitosan film as dressing for punch biopsy wounds in rats. Journal of Pharmacy \& Pharmaceutical Science. v. 6, n. 1, p. 20-26, 2003.

$\mathrm{KIM}$, J.; YUN, H.; CHO, Y. Analysis of ceramide metabolites in differentiating epidermal keratinocytes treated with calcium or vitamin C. Nutrition Research and Practice, v. 5, n. 5, p. 396-403, 2011.

KOKANE, D. D.; MORE, R. Y.; KALE, M. B.; NEHETE, M. N.; MEHENDALE, P. C.; GADGOLI, C. H. Evaluation of wound healing activity of root of Mimosa pudica. Journal of Ethnopharmacology, v. 124, p. 311-315, 2009.

KOMARCEVIC, A. The modern approach to wound treatment. Medicinski Pregled, v. 53, n. 78, p. $363-368,2000$.

KOSAKA, T.; KANEKO, Y.; NAKADA, Y.; MATSUURA, A.; TANAKA, S. Effect of chitosan implantation on activation of canine macrophages and polymorphonuclear cells after surgical stress. Journal of veterinary medical science, v. 58, n. 10, p. 963-967, 1996.

KUCHARSKA, M.; NIEKRASZEWICZ, A.; WIŠNIEWSKA-WRONA, M.; BRZOZA-MALCZEWSKA, K. Dressing sponges made of chitosan and chitosan-alginate fibrids. Fibres \& Textiles in Eastern Europe, v. 16, n. 3, p. 109-113, 2008.

KUMAR, M.S.; KIRUBANANDAN, S.; SRIPRIYA, R.; SEHGAL, P.K. Triphala promotes healing of infected full-thickness dermal wound. Journal of Surgical Research, v. 144, p. 94-101, 2008. 
KUMAR, V.; ABBAS, A. K.; FAUSTO, N. Robbins \& Cotran. Patologia: bases patológicas das doenças. 7 ed. Rio de Janeiro. Saunders. 2005. p. 49-124.

LAWRENCE, W. T; DIEGELMANN, R. Growth factors in wound healing. Clinics in Dermatology, v. 12, n. 1, p. 157-69, 1994.

LAWRENCE, W. T. Physiology of the acute wound. Clinics in Plastic Surgery, v. 25, n. 3, p. 321-340, 1998.

LAZARUS, G. S; COOPER, D. M.; KNIGHTON, D. R.; MARGOLIS, D. J.; PERCORARO, R. E.; RODEHEAVER, G.; ROBSON, M. C. Definitions and guidelines for assessment of wounds and evaluation of healing. Wound Repair and Regeneration, v. 2, n. 3, p. 165-170, 1994.

LEE, J. W.; KIM, S. Y.; KIM, S. S.; LEE, Y. M.; LEE, K. H.; KIM, S. J. Synthesis and Characteristics of Interpenetrating Polymer network Hydrogel Composed of Chitosan and Poly (acrylic acid). Journal of Applied Polymer Science, v. 73, n. 1, p. 113-120, 1999.

LEIBOVICH, S. J., ROSS, R. The role of the macrophage in the wound repair: American Journal of Pathology, v.78, p.71-100. 1975.

LEITE, S. N; JORDÃO-JÚNIOR, A. A; ANDRADE, T. A; MASSON, DOS S; FRADE, M. A. Experimental models of malnutrition and its effect on skin trophism. Anais Brasileiros de Dermatologia, v. 86, n. 4, p. 681-688, 2011.

LEUNG, M.; KIEVIT, F. M.; FLORCZYK, S. J.; VEISEH, O.; WU, J.; PARK, J. O.; ZHANG, M. Chitosan-Alginate Scaffold Culture System for Hepatocellular Carcinoma Increases Malignancy and Drug Resistance. Pharmaceutical Research, v. 27, n. 9, p. 1939-1948, 2010.

LI, J.; CHEN, J.; KIRSNER, R. Pathophysiology of acute wound healing. Clinics in Dermatology, v. 25, n. 1, p. 9-18, 2007.

LI, X.; XIE, H.; LIN, J.; XIE, W.; MA, X. Characterization and biodegradation of chitosanalginate polyelectrolyte complexes. Polymer Degradation and Stability, v. 94, n. 1, p. 1-6, 2009.

LI, Z.; RAMAY, H. R.; HAUCH, K. D.; XIAO, D.; ZHANG, M. Chitosan-alginate hybrid scaffolds for bone tissue engineering. Biomaterials, v. 26, n. 18, p. 3919-28, 2005.

LI, Z.; ZHANG, M. Chitosan-alginate as scaffolding material for cartilage tissue engineering. Journal of Biomedical Materials Research, Part A, v. 75A, n. 2, p. 485-93, 2005.

LIM, S. M.; SONG, D. K.; OH, S. H.; LEE-YOON, D. S.; BAE. E. H.; LEE, J. H. In vitro and in vivo degradation behavior of acetylated chitosan porous beads. Journal of Biomaterials Science, Polymer Edition, v. 19, n. 4, p. 453-66, 2008. 
LIMA E COSTA, M. F.; GUERRA, H. L.; BARRETO, S. M.; GUIMARÃES, R. M. Diagnóstico da situação de saúde da população idosa brasileira: um estudo da mortalidade e das internações hospitalares públicas. Informe Epidemiológico do SUS, v. 9, n .1, p. 23-41, 2000.

LOBMANN, R.; AMBROSCH, A.; SCHULTZ, G.; WALDMANN, K.; SCHIWECK, S.; LEHNERT, H. Expression of matrixmetalloproteinases and their inhibitors in the wounds of diabetic and non-diabetic patients. Diabetologia, v. 45, n. 7, p. $1011-6,2002$.

LOBMANN R, SCHULTZ G, LEHNERT $H$. Proteases and the diabetic foot syndrome: mechanisms and therapeutic implications. Diabetes Care, v. 28, n. 2, p. 461- 71, 2005.

MALAFAYA, P. B.; SILVA, G. A.; REIS, R. L. Natural-origin polymers as carriers and scaffolds for biomolecules and cell delivery in tissue engineering applications. Advanced Drug Delivery Reviews, v. 59, n. 4-5, p. 207-233, 2007.

MANDELBAUM, S. H.; DI SANTIS, E. P.; MANDELBAUM, M. H. S. Cicatrização: conceitos atuais e recursos auxiliares - Parte I. Anais Brasileiros de Dermatologia, v. 78, n. 4, p. 393-410, 2003.

MARTIN, P., LEIBOVICH, S. J. Inflammatory cells during wound repair: the good, the bad and the ugly. Trends in Cell Biology, v. 15, n. 11, p. 599-607, 2005.

MAST, B. A.; SCHULTZ, G. S. Interactions of cytokines, growth factors, and proteases in acute and chronic wounds. Wound Repair and Regeneration, v. 4, n. 4, p. 411-20, 1996.

MATHIEU, D.; LINKE, J. C.; WATTEL, F. Non-healing wounds. In: MATHIEU D. E., Handbook on hyperbaric medicine, Netherlands: Springer, 2006. p. 401-427.

MCHUGH, D. J. A guide to the seaweed industry. FAO Fisheries Technical Paper 441. Food and Agriculture Organization of the United Nations, 2003. Disponível em: <http://www.fao.org/docrep/006/Y4765E/y4765e00.HTM>. Acesso em: 26 Jan.2012.

MENKE, M. N.; MENKE, N. B.; BOARDMAN, C. H.; DIEGELMANN, R. F. Biologic therapeutics and molecular profiling to optimize wound healing. Gynecologic Oncology, v. 111, n. 2 p. S87-S91, 2008.

MENKE, N. B; WARD, K. R.; WITTEN, T. M.; BONCHEV, D. G.; DIEGELMANN, R. F. Impaired wound healing. Clinics in Dermatology, v. 25, n. 1, p. 19-25, 2007.

MESZAROS, A. J.; REICHNER, J. S.; ALBINA, J. E. Macrophage-induced neutrophil apoptosis. The Journal of Immunology, v. 165, n. 1, p. 435-441, 2000.

MINATEL, D. G.; FRADE, M. A. C; FRANCA, S.; ENWEMEKA, C. S. Phototherapy promotes healing of chronic diabetic leg ulcers that failed to respond to other therapies. Lasers in Surgery and Medicine, v. 41, p. 433-441, 2009. 
MONACO, J. L.; LAWRENCE, T. Acute wound healing an overview. Clinics in Plastic Surgery, Philadelphia, v. 30, p. 1-12, 2003.

MOON, J. J.; MATSUMOTO, M.; PATEL, S.; LEE, L.; GUAN, J.; LI, S. Role of cell surface heparin sulphate proteoglycans in endothelial cell migration and mechanotransduction. Journal of Cellular Physiology, v. 203, p. 166 - 167, 2005.

MOSSER, D. M.; EDWARDS, J. P. Exploring the full spectrum of macrophage activation. Nature Reviews Immunology, v. 8, n. 12, p. 958-969, 2008.

MUZZARELLI, R. A. A. Chitins and chitosans for the repair of wounded skin, nerve, cartilage and bone. Carbohydrate Polymers, v.76, p. 167-182, 2009.

NARDI, A.B.; RODASKI, S.; SOUSA, R.S.; BAUDI, D.L.K.; CASTRO, J.H.T. Cicatrização secundária em feridas dermoepidérmicas tratadas com ácidos graxos essenciais, vitaminas $A$ e $E$, lecitina de soja e iodo polivinilpirrolidona em cães. Archives of Veterinary Science, v. 9, n. 1, p. 1-16, 2004.

NAYAK, B.S.; KANHAI, J.; MILNE, D.M.; PEREIRA, L.P.; SWANSTON, W.H. Experimental evaluation of ethanolic extract of Carapa guianensis L. leaf for its wound healing activity using three wound models. Evidence-based complementary and alternative medicine (eCAM), v. 2011, p. 1-7, 2011.

OIKE, Y.; ITO, Y.; MAEKAWA, H.; MORISADA, T.; KUBOTA, Y.; AKAO, M.; URANO, T.; YASUNAGA, K.; SUDA, T. Angiopoietin-related growth factor (AGF) promotes angiogenesis. Blood, v. 103, n. 10, p. $3760-3765,2004$.

OZTURK, E.; AGALAR, C.;KEÇECI, K.; DENKBAS, E. B. Preparation and Characterization of Ciprofloxacin-Loaded Alginate/Chitosan Sponge as a Wound Dressing Material. Journal of Applied Polymer Science, v. 101, p. 1602-1609, 2006.

PARSONAGE, G.; FILER, A. D.; HAWORTH, O.; NASH, G. B.; RAINGER, G. E.; SALMON, M. BUCKLEY, C. D. A stromal address code defined by fibroblasts. Trends in Immunology. v. 26, n. 3, p. 150-156, 2005.

PAUL, W.; SHARMA, C. P. Chitosan and alginate wound dressings: a short review. Trends in Biomaterials \& Artificial Organs, v. 18, n. 1, p. 18-23, 2004.

PEI, H. N.; CHEN, X. G.; LI, Y.; ZHOU, H. Y. Characterization and ornidazole release in vitro of a novel composite film prepared with chitosan/poly(vinyl alcohol)/alginate. Journal of. Biomedical. Materials. Research Part A, v. 85, n. 2, p. 566-572, 2008.

PIERCE, G. F.; MUSTOE, T. A.; ALTROCK, B. W.; DEUEL, T. F.; THOMASON, A. Role of plateletderived growth factor in wound healing. Journal of Cellular Biochemistry, v. 45, n. 4, p. 319326, 1991. 
QI, J.; CHEN, A.; YOU, H.; LI, K.; ZHANG, D.; GUO, F. Proliferation and chondrogenic differentiation of CD105-positive enriched rat synovium-derived mesenchymal stem cells in three-dimensional porous scaffolds. Biomedical. Materials, v. 6, n. 1, p. 1-10, 2011.

RAMASASTRY, S. S. Acute wounds. Clinics in Plastic Surgery, v. 32, p. 195 - 208, 2005.

RANZATO E, MARTINOTTI S, BURLANDO B. Wound healing properties of jojoba liquid wax: an in vitro study. Journal of Ethnopharmacology, v. 134, n. 2, p. 443-9, 2011.

REDDY, A. S.; KALYANI, S.; KUMAR, N. S.; BODDU, V. M.; KRISHNAIAH, A. Dehydration of 1,4dioxane by pervaporation using crosslinked calcium alginate-chitosan blend membranes. Polymer Bulletin, v. 61, n. 6, p. 779-790, 2008.

REDDY, G. K.; ENWEMEKA, C. S. A simplified method for the analysis of hydroxyproline in biological tissues. Clinical Biochemistry, v. 29, n. 3, 225-229, 1996.

REHDER, J.; SOUTO, L. R. M.; ISSA, C. M. B. M.; PUZZI, M. B. Model of human epidermis reconstructed in vitro with keratinocytes and melanocytes on dead de-epidermized human dermis. São Paulo Medical Journal, v. 122, n. 1, p. 22-25, 2004.

RICHARDSON, M. Acute wounds: an overview of the physiological healing process. Nursing Times, v. 100, n. 4, p. 50-53, 2004.

RINAUDO, M. Main properties and current applications of some polysaccharides as biomaterials. Polymer International, v. 57, n. 3, p. 397-430, 2008.

ROBSON, M. C.; HILL, D. P.; WOODSKE, M. E.; STEED, D. L. Wound healing trajectories as predictors of effectiveness of therapeutic agents. Archives of Surgery. v. 135, n. 7, p. 773$777,2000$.

ROBSON, M. C.; STEED, D. L.; FRANZ, M. G. Wound healing: biologic features and approaches to maximize healing trajectories. Current Problems in Surgery, v. 38, n. 2,p. 72-140, 2001.

RODEMANN, H. P.; MULLER, G. A. Characterization of human renal fibroblasts in health and disease: II. In vitro growth, differentiation, and collagen synthesis of fibroblasts from kidneys with interstitial fibrosis. American. Journal of. Kidney Diseases, v. 17, p. 684-686, 1991.

RODRIGUES, A. P. Preparação e caracterização de membranas de quitosana e alginato para aplicação na terapia de lesões. 2008. Tese (Doutorado em engenharia química) - Faculdade de Engenharia Química, Universidade Estadual de Campinas, 2008.

RODRIGUES, A. P. Produção de caracterização de micropartículas de alginato incorporando Aeromonas Hydrophila inativada para imunização de Tilápia do Nilo por via oral. 2004. Dissertação (Mestrado em engenharia química) - Faculdade de Engenharia Química, Universidade Estadual de Campinas, 2004. 
ROLDÁN-MARÍN, R.; CONTRERA-RUIZ, J.; ARENAS, R.; VAZQUEZ-DEL- ERCADO, E.; CAIRETOUSSANIT; MEMIJE-VEGA, ME. Fixed sporotrichosis as a cause of a chronic ulcer on the knee. International Wound Journal, v. 6, n. 1, p .63- 66, 2009.

ROLSTAD, B.S.; BRYANT, R.A.; NIX, D.P. Topical management. In: BRYANT, R.A.; NIX, D.P. Acute and chronic wounds: current management concepts. 4th ed. Missouri: Elsevier Mosby, 2012. cap. 18, p. 289-306.

RUGGERI, Z. M. Platelets in atherothrombosis. Nature Medicine, v. 8, n. 11, p. 1227-1234, 2002.

SAETHER, H. V.; HOLME, H. K.; MAURSTAD, G.; SMIDSR ØD, O.; STOKKE, B. T. Polyelectrolyte complex formation using alginate and chitosan. Carbohydrate Polymers, v. 74, n. 4, p. 813821, 2008.

SANKALIA, M. G.; MASHRU, R. C.; SANKALIA, J. M.;SUTARIYA, V. B. Reversed chitosanalginate polyelectrolyte complex for stability improvement of alpha-amylase: optimization and physicochemical characterization. European Journal of Pharmaceutics and Biopharmaceutics, v. 65, n. 2, p. 215-232, 2007.

SCHMIDT, C.; FRONZA, M.; GOETTERT, M.; GELLER, F.; LUIK, S.; FLORES, E.M.M.; BITTENCOURT, C.F.; ZANETTI, G.D.; HEINZMANN, B.M.; LAUFER, S.; MERFORT, I. Biological studies on Brazilian plants used in wound healing. Journal of Ethnopharmacology, v. 122, n. 3, p. 523-532, 2009.

SCHULTZ, G. S.; DAVIDSON, J. M.; KIRSNER, R. S.; BORNSTEIN, P.; HERMAN, I. M. Dynamic reciprocity in the wound microenvironment. Wound Repair and Regeneration, v. 19, n. 2, p. 134-148, 2011.

SEHN, E.; HERNANDES, L.; FRANCO, S. L.; GOLÇALVES, C. C. M.; BAESSO, M. L. Dynamics of reepithelialisation and penetration rate of a bee propolis formulation during cutaneous wounds healing. Analytica Chimica Acta, v. 635, n.1, p. 115-120, 2009.

SHAI, A.; MAIBACH, H. I. Antibiotics, antiseptics and cutaneous ulcers. In: Wound healing and ulcers of the skin. Diagnosis and Therapy - the pratical approach. Germany: Springer, 2005. p.135-150.

SILVA, S. S. Processing and surface modification of novel naturalorigin architectures aimed for biomedical aplications. 2008. [s.p.] Tese (Doutorado em Ciencias e Tecnologia de Materiais) - Escola de Engenharia, Universidade do Minho, Portugal, 2008.

SIMIAN, M.; HIRAI, Y.; NAVRE, M.; WERB, Z.; LOCHTER, A.; BISSELL, M. J. The interplay of matrix metalloproteinases, morphogens and growth factors is necessary for branching of mammary epithelial cells. Development, v. 128, n. 16, p. 3117-3131, 2001. 
SOUZA, D. G.; CASSALI, G. D.; POOLE, S.; TEIXEIRA, M. M. Effects of inhibition of PDE4 and TNF-alpha on local and remote injuries following ischaemia and reperfusion injury. British Journal of Pharmacology, v. 134, n. 5, p. 985-94, 2001.

SPRINGER, T. A. Traffic signals for lymphocyte recirculation and leukocyte emigration: the multistep paradigm. Cell, v. 76, n. 2, p. 301-314, 1994.

STASHAK, T. S.; FARSTVEDT, E.; OTHIC, A. Update on wound dressing: indications and best use. Clinical Techniques in Equine Practice. v. 3, n. 2, p. 148-163, 2004.

STANDEVEN, K. F.; ARIENS, R. A. S.; GRANT, P. J. The molecular physiology and pathology of fibrin structure/function. Blood Reviews, v. 19, n. 5, p. 275-288, 2005.

STOJADINOVIC, A.; CARLSON, J.W.; SCHULTZ, G.S.; DAVIS, T.A.; ELSTER, E.A. Topical advances in wound care. Gynecologic Oncology, v. 111, n. 2, p. S70-S80, 2008.

STRECKER-MCGRAW, M.K.; JONES, T. R.; BAER, D. G. Soft tissue wounds and principles of healing. Emergency Medicine Clinics of North America, v. 25, n. 1, p. $1-22,2007$.

STRONCEK, J. D; BELL, N; REICHERT, W. M. Instructional powerpoint presentations for cutaneous wound healing and tissue response to sutures. Journal of Biomedical Materials Research, v. 90A, n. 4, p.1230-1238, 2009.

SUN, Q. H.; SILVA, E. A.; WANG, A. X.; FRITTON, J. C.; MOONEY, D. J.; SCHAFFLER, M. B.; GROSSMAN, P. M.; RAJAGOPALAN, S. Sustained release of multiple growth factors from injectable polymeric system as a novel therapeutic approach towards angiogenesis. Pharmaceutical Research, v. 27, p. 264-71, 2010.

SUZUKI, T.; MIZUSHIMA, Y. Characteristics of silica-chitosan complex membrane and their relationships to the characteristics of growth and adhesiveness of L-929 cells cultured on the biomembrane. Journal of Fermentation and Bioengineering, v. 84, n. 2, p. 128-132, 1997.

SWAIN, S. D.; ROHN, T. T.; QUINN, M. T. Neutrophil priming in host defense: Role of oxidants as priming agents. Antioxidants \& Redox Signaling, v. 4, n. 1, p. 69-83, 2002.

THEORET, C. Tissue Engineering in Wound Repair: The three " $R$ "s-Repair, Replace, Regenerate. Veterinary Surgery, v. 38, p. 905-913, 2009.

TOMASEK, J. J.; GABBIANI, G.; HINZ, B.; CHAPONNIER, C.; BROWN, R. A. Myofibroblasts and mechanoregulation of connective tissue remodelling. Nature Reviews. Molecular. Cell Biology, v. 3, p. 349-363, 2002.

VANWIJCK, R. Surgical biology of wound healing. Bulletin et Memoires de I'Academie Royale de Médicine de Belgique, v. 156, n. 3-4, p. 175-184, 2001. 
VELNAR, T.; BAILEY, T.; SMRKOLJ, V. The Wound Healing Process: an Overview of the Cellular and Molecular Mechanisms. The Journal of International Medical Research, v. 37, n. 5, p. 1528-1542, 2009.

WANG, L.; KHOR, E.; LIM, L. Y. Chitosan-alginate- $\mathrm{CaCl}_{2}$ system for membrane coatapplication. Journal of Pharmaceutical Sciences, v. 90, n. 8, p. 1134-1142, 2001.

WANG, L.; KHOR, E.; WEE, A.; LIM, L. Y. Chitosan-alginate PEC membrane as wound dressing: assessment of incisional wound healing. Journal of Biomedical Materials Research, v. 63, n. 5, p. 610-618, 2002.

WANG, Y. C.; KAO, S. H.; HSIEH, H. J. A chemical surface modification of chitosan by glycoconjugates to enhance the cell-biomaterial interaction. Biomacromolecules, v. 4, n. 2, p. 224-231., 2003.

WATT, F. M. The epidermal keratinocyte. BioEssays, v. 8, n. 5, p. 163-7, 1988.

WHITNEY, J. D. Overview: acute and chronic Wounds. Nursing Clinics of North America, v. 40, n. 2, p. 191-205, 2005.

WIEGAND, C.; HIPLER, U. Polymer-based Biomaterials as Dressings for Chronic Stagnating Wounds. Macromolecular Symposia, v. 294, n. 2, p. 1-13, 2010.

WISEMAN, B. S.; WERB, Z. Stromal effects on mammary gland development and breast cancer. Science, v. 296, n. 5570, p. 1046-1049, 2002.

YAGER, D., NWOMEH, B. The proteolytic environment of chronic wounds. Wound Repair and Regeneration, v. 7, p. 433-441, 1999.

YANG, X.; KHOR, E.; LIM, L. Y. PEC films prepared from chitosan-alginate coacervates. Chemical and Pharmaceutical Bulletin, v. 48, n. 7, p. 941-946, 2000.

YUDANOVA, T. N.; RESHETOV, I. V. Modern wound dressings: manufacturing and properties. Pharmaceutical Chemistry Journal, v. 40, n. 2, p. 85-92, 2006.

ZHANG, Q. X.; MAGOVERN, C. J.; MACK, C. A.; BUDENBENDER, K. T.; KO, W.; ROSENGART, T. K. Vascular endothelial growth factor is the major angiogenetic factor in omentum: mechanism of the omentum mediated angiogenesis. Journal Surgical Research, v. 67, n. 2, p. 147-154, 1997. 